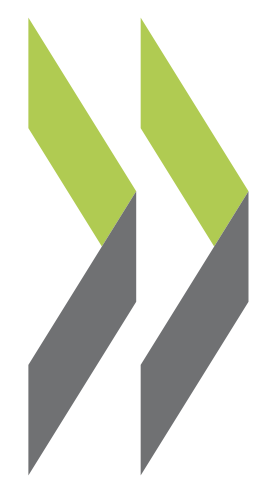

OECD Economics Department Working Papers No. 1604

\section{The 2018 edition of the OECD PMR}

indicators and database: Methodological improvements and policy insights
Cristiana Vitale,

Rosamaria Bitetti, Isabelle Wanner, Eszter Danitz, Carlotta Moiso 


\section{ECONOMICS DEPARTMENT}

2 April 2020

Cancels \& replaces the same document of 17 March 2020

THE 2018 EDITION OF THE OECD PMR INDICATORS AND DATABASE METHODOLOGICAL IMPROVEMENTS AND POLICY INSIGHTS

\section{ECONOMICS DEPARTMENT WORKING PAPERS No.1604}

By Cristiana Vitale, Rosamaria Bitetti, Eszter Danitz, Carlotta Moiso, Isabelle Wanner.

OECD Working Papers should not be reported as representing the official views of the OECD or of its member countries. The opinions expressed and arguments employed are those of the author(s).

Authorised for publication by Alain de Serres, Deputy Director Policy Studies Branch, Economics Department.

All Economics Department Working Papers are available at www.oecd.org/eco/workingpapers. 
OECD Working Papers should not be reported as representing the official views of the OECD or of its member countries. The opinions expressed and arguments employed are those of the author(s).

Working Papers describe preliminary results or research in progress by the author(s) and are published to stimulate discussion on a broad range of issues on which the OECD works.

Comments on Working Papers are welcomed, and may be sent to OECD Economics Department,

2 rue André Pascal, 75775 Paris Cedex 16, France, or by e-mail to eco.contact@oecd.org.

This document and any map included herein are without prejudice to the status of or sovereignty over any territory, to the delimitation of international frontiers and boundaries and to the name of any territory, city or area.

The statistical data for Israel are supplied by and under the responsibility of the relevant Israeli authorities. The use of such data by the OECD is without prejudice to the status of the Golan Heights, East Jerusalem and Israeli settlements in the West Bank under the terms of international law.

\section{(C) OECD (2020)}

You can copy, download or print OECD content for your own use, and you can include excerpts from OECD publications, databases and multimedia products in your own documents, presentations, blogs, websites and teaching materials, provided that suitable acknowledgment of OECD as source and copyright owner is given. All requests for commercial use and translation rights should be submitted to rights@oecd.org. 


\section{ABSTRACT \\ THE 2018 EDITION OF THE OECD PMR INDICATORS AND DATABASE - METHODOLOGICAL IMPROVEMENTS AND POLICY INSIGHTS}

This paper presents the latest edition of the OECD indicators of product market regulation (PMR), which measure regulatory stance in 35 OECD and 11 non-OECD countries. This update is based on a new methodology, which has been implemented to ensure that the PMR indicators maintain their relevance in the context of evolving insights from economic theory, modifications in the economic and business environment, and changes in the practice of regulation. The results show that most OECD countries have a regulatory stance that is reasonably competition-friendly, while the 11 non-OECD countries lag behind, though there is considerable variety across them. The regulatory domains in which reforms are most needed across the majority of the countries surveyed appear to be: aligning the corporate governance of state-owned enterprises with OECD bets practice Guidelines, ensuring transparency and accountability in the interaction between policymakers and interest groups, removing barriers to entry in retail trade and professional services, and reducing red tape for new firms.

Keywords: product market regulation

JEL codes : D4, K230, L1, L2, L3, L5, L8, L9

\section{RÉSUMÉ}

\section{EDITION 2018 DES INDICATEURS ET DE LA BASE DE DONNÉES DU PMR DE L'OCDE - AMÉLIORATIONS METHODOLOGIQUES ET PERSPECTIVES POLITIQUES}

Cette publication présente la dernière édition des indicateurs de réglementation des marchés de produits (RMP) de I'OCDE, qui évaluent l'orientation réglementaire dans 35 pays membres et 11 pays non membres de l'OCDE. Cette mise à jour repose sur une nouvelle méthodologie, adoptée pour veiller à ce que les indicateurs de RMP restent pertinents face à l'évolution des éclairages apportés par la théorie économique, à la modification de la conjoncture économique et de l'environnement des entreprises, et aux changements observés dans les pratiques réglementaires. Les résultats montrent que, dans la plupart des pays de l'OCDE, l'orientation de la réglementation est relativement favorable à la concurrence, tandis que les 11 pays non membres de I'OCDE affichent du retard dans ce domaine, même si la situation varie considérablement de l'un à l'autre. Les domaines de la réglementation où les besoins de réforme sont les plus importants dans la majorité des pays considérés semblent être les suivants : aligner la gouvernance des entreprises publiques sur les lignes directrices de l'OCDE, assurer la transparence et la reddition de comptes dans les interactions entre les responsables de l'action publique et les groupes d'intérêts, éliminer les barrières à l'entrée dans les secteurs du commerce de détail et des services professionnels, et simplifier les formalités administratives pour les nouvelles entreprises.

Mots clés : réglementation du marché de produits

codes JEL: D4, K230, L1, L2, L3, L5, L8, L9 


\section{Table of contents}

The 2018 Edition of the OECD PMR Indicators and Database - Methodological Improvements and Policy Insights

1. Introduction

1.1 Key highlights

2. An outline of the PMR methodology 11

2.1 How PMR indicators are calculated 11

2.2 The 2018 economy-wide PMR indicator $\quad 11$

2.3 The 2018 sector PMR indicators 13

3. Product market regulation in 2018: the economy-wide regulatory stance 15

3.1 The current economy-wide regulatory stance at aggregate level 15

$\begin{array}{ll}3.2 \text { Going beyond the overall score } & 19\end{array}$

3.3 Detailed insights: the low-level indicators 21

4. Product market regulation in 2018: the regulatory stance at the sector level 34

4.1 Network Sectors 34

$\begin{array}{lll}4.2 & \text { Service Sectors } & 40\end{array}$

Annex A. Values of all economy-wide PMR indicators 49

Annex B. Values of all sector PMR indicators $\quad 56$

Annex C. How have the PMR indicators changed in 2018? 61

$\begin{array}{ll}\text { A revised questionnaire } & 61\end{array}$

A revised scoring methodology $\quad 62$

The 2018 structure of the economy-wide PMR indicator and the differences with the 2013 structure 62

The difference in the structure of the sector PMR indicators between 2013 and 201865

References 66 


\section{Tables}

Table 1. Average values for the four transport sectors

Table 2. Average values for the six professions

Table A.1. Values of the overall economy-wide indicator, the two high-level indicators, and the six mediumlevel ones (OECD countries)

Table A.2. Values of the low-level indicators included in Distortions induced by State Involvement

Table A.3. Values of the low-level indicators included in Barriers to Domestic and Foreign Entry (OECD countries)

Table B.1. Values of the indicators for network sectors: Energy, E-communications and Transport (OECD countries)

Table B.2. Values of the indicators for professional services and for retail distribution (OECD countries)

\section{Figures}

Figure 1: Scope for improvement at the economy-wide level (OECD countries) 10

Figure 2: Scope for improvement at the sector level (OECD countries) 10

Figure 3. Structure of the 2018 PMR economy-wide indicator 12

Figure 4. Structure of the 2018 PMR indicators for Network Sectors 13

Figure.5. Structure of the 2018 PMR indicators for Professional Services 14

Figure 6. The structure of the 2018 PMR indicators for Retail Distribution 14

Figure 7. The economy-wide PMR indicator in 2018

Figure 8. The economy-wide PMR indicator in 2018 (random weights analysis) 17

Figure 9. Distortions induced by State Involvement in 2018 (random weights analysis) 20

Figure 10. Barriers to Domestic and Foreign Entry in 2018 (random weights analysis) 21

Figure 11. Composition of the high-level indicator Distortions Induced by State Involvement 22

Figure 12. Low-level indicator on the Scope of SOEs in $2018 \quad 24$

Figure 13. Low-level indicator on Government Involvement in Network Sectors in 2018

Figure 14. Low-level indicator on Governance of SOEs in $2018 \quad 26$

$\begin{array}{ll}\text { Figure 15. Low-level indicator on Public Procurement in } 2018 & 27\end{array}$

Figure 16. Low-level indicator on the Assessment of Impact on Competition in 2018

Figure 17. Low-level indicator on the Interaction with Interest Groups in $2018 \quad 28$ 
6 | ECO/WKP(2020)12

Figure 18. Composition of the high-level indicator: Barriers to Domestic and Foreign Entry

Figure 19. Low-level indicator on Administrative Requirements for Limited Liability Companies and Personally Owned Enterprises in 2018

Figure 20. Low-level indicator on Licences and Permits in 2018

Figure 21. Low-level Indicator on Barriers in Service Sectors in 2018

Figure 22. Low-level Indicator on Barriers in Network Sectors in 2018

Figure 23. Low-level Indicator on Treatment of Foreign Suppliers in 2018

Figure 24. PMR sector indicators for the E-communication fixed and mobile sectors*

Figure 25. Public ownership and regulation in the Fixed E-communications sector*

Figure 26. Public ownership and regulation in the Mobile E-communications sector*

Figure 27. PMR sector indicators for the Energy Sector*

Figure 28. Public ownership and regulation in the Electricity sector*

Figure 29. Public ownership and regulation in the Natural Gas sector*

Figure 31. PMR sectoral indicators for Accountants

Figure 32. PMR sector indicators for Architects

Figure 33. PMR sector indicators for Civil Engineers

Figure 34. PMR sector indicators for Real Estate Agents

Figure 35. PMR sector indicators for Lawyers

Figure 36. PMR sector indicators for Notaries*

Figure 37. PMR sector indicators for Retail Trade

Figure 38. PMR sector indicators for Retail Sale of Medicines

Figure.39. Structure of the 2018 economy-wide PMR indicator with changes highlighted

\section{Boxes}

Box 1. The random weights analysis 


\title{
The 2018 Edition of the OECD PMR Indicators and Database - Methodological Improvements and Policy Insights
}

\author{
By Cristiana Vitale, Rosamaria Bitetti, Eszter Danitz, Carlotta Moiso, Isabelle Wanner ${ }^{1}$
}

\section{Introduction}

1. Pro-competition regulation in the markets for goods and services can help boost living standards. Pro-competition regulatory reforms can raise output per capita by increasing investment and employment, and may help to reduce income inequality. Competition can also encourage companies to be more innovative and efficient, thereby lifting productivity. See for example Ahn (2002), Aghion et al (2004, 2005, and 2009), Bloom et al. (2011), Blundell, Griffith and Van Reenen (1999), Causa et al., (2016), Disney, Haskell and Heden (2003), Fiori et al. (2012), Griffith et al (2007), Januszewski (2002), Nickell (1996).

2. In order to benefit from these economic gains, many countries, especially in the OECD, have worked on removing unnecessary obstacles to competition over the past decades. Nevertheless, there is room for further reforms.

3. To measure a country's regulatory stance and to track reform progress over time in 1998 the OECD developed a set of indicators of product market regulation (PMR) (Nicoletti et al., 2000). This set included an economy-wide PMR indicator and a group of indicators that measures regulation at the sector level. These PMR indicators were updated in 2003 (Conway et al., 2006), in 2008 (Wölfl et al., 2009) and in 2013 (Koske et al. 2015).

\footnotetext{
${ }^{1}$ Cristiana Vitale, Rosamaria Bitetti, Eszter Danitz, Carlotta Moiso, Isabelle Wanner (all OECD Economics Department) wish to thank Christiane Arndt-Bascle, Benjamin Gerloff, Paul Davidson, Pauline Bertrand and Levke Jessen-Thiesen from the Public Governance Directorate, Korin Kane, Hans Christiansen, the Competition Division and Fernando Mistura from the Department for Financial and Enterprise Affairs, and Frederic Gonzales, Hildegunn Nordas, and Silvia Sorescu from the Trade and Agriculture Directorate for their contribution to the PMR data collection and verification. They also owe a lot to Professor Martin Cave and Mr David Halldearn for their help in redesign some sections of the PMR questionnaire. Last, but not least they thank colleagues from the OECD Economics Department, Laurence Boone, Caroline Klein, Balazs Egert, Asa Johannsson, Alain de Serres, and Luiz de Mello as well as participants in the Working Party No. 1 of the Economic Policy Committee for useful comments and suggestions.
} 


\section{$\mathbf{8} \mid \operatorname{ECO} / \mathrm{WKP}(2020) 12$}

4. Over time, the PMR indicators have become an essential element of the OECD's policy analysis toolkit, as they enhance the knowledge of regulatory practices in individual countries and permit to investigate their link with economic performance. The PMR indicators form an integral part of the Going for Growth exercise and OECD Economic Surveys, where they are used to formulate recommendations for policy reforms. These indicators and their underlying data are also extensively used by national governments, other international organisations (e.g. IMF, WB, and European Union), and international forums, such as the G20 and APEC, to determine areas for regulatory refroms. Academics and research institutions are wide users of these indicators, as they are the most extensive quantitative measure of the quality of regulation in good and service markets currently available.

5. Indeed the PMR indicators have helped to better analyse the role that regulation can play in affecting multi factor productivity. There is now considerable empirical evidence that anticompetitive regulations in markets for goods and services are associated with lower multi factor productivity levels and that reforms removing such constraints on competition have an impact on productivity (see for example Barnes et al. (2011), Bouis and Duval (2011), Bourlès et al. (2010), Égert (2016, 2017, 2017a and 2018), Égert and Gal (2017), Egert and Wanner (2016), Parker and Kirkpatrick (2012)),

6. This paper presents the results of the 2018 update of the OECD economy-wide and sector PMR indicators. It includes results for 35 OECD countries, i.e. all OECD members, except the United States for which the data collection had not yet been completed at the time of publication, and for 11 non-OECD countries, namely: Argentina, Brazil, Bulgaria, Colombia, Costa Rica, Croatia, Cyprus ${ }^{2}$, Kazakhstan, Malta, Romania and South Africa.

7. The 2018 PMR indicators are based on a new methodology. A different questionnaire has been used to collect the information that feed into the PMR database and the structures of the economy-wide indicators and of the sector PMR indicators have changed. These modifications have been made to ensure that the PMR indicators maintain their relevance in the context of evolving insights from economic theory, modifications in the economic and business environment, and changes in the practice of regulation. Because of these changes, the values herein presented can only be compared across countries, but not with previous vintages of the economy-wide and sector PMR indicators.

8. The rest of this paper is composed of four more sections: Section 2, which outlines the 2018 PMR methodology, Section 3, which presents the results for the economy-wide indicators, Section 4, which presents the results for the sector indicators, and Section 5 , which provides some policy conclusions.

9. The paper also includes three Annexes: Annex A and Annex B, which list respectively the values of all the economy-wide and all the sector PMR indicators, and Annex $\mathrm{C}$, which explains in details how the PMR indicators have changed in 2018 with respect to previous vintages.

\footnotetext{
2 1. Note by Turkey:
}

The information in this document with reference to "Cyprus" relates to the southern part of the Island. There is no single authority representing both Turkish and Greek Cypriot people on the Island. Turkey recognises the Turkish Republic of Northern Cyprus (TRNC). Until a lasting and equitable solution is found within the context of the United Nations, Turkey shall preserve its position concerning the "Cyprus issue".

2. Note by all the European Union Member States of the OECD and the European Union:

The Republic of Cyprus is recognised by all members of the United Nations with the exception of Turkey. The information in this document relates to the area under the effective control of the Government of the Republic of Cyprus 


\subsection{Key highlights}

10. The results for the 2018 economy-wide PMR indicator show that most OECD countries have a regulatory stance that is reasonably competition-friendly. However, an analysis of the sub-level components of this indicator shows greater variation across countries in the underlying regulatory areas and indicates that there is still room for improvements in some areas.

11. The regulatory domains in which reforms are the most pressing vary country by country, but some general trends can be identified on the basis of OECD averages and variance for the 18 sub-indicators (Figure 1):

- Public ownership of firms across the economy is still quite widespread among OECD and nonOECD countries, both in terms of the number of sectors in which governments control at least one firm and of the amount of shares they own in the largest firms in key network sectors. While it might be justified for governments to retain a certain level of participation in specific sectors, there may be room for further reducing their presence in others.

- Many countries could better regulate the interaction of legislators and policymakers with interest groups to enhance transparency and accountability. This would ensure that undue influence in the law-making process could be more easily identified and addressed.

- More effort could also be undertaken to reduce red tape for new firms. Despite a reduction in the number of administrative requirements that start-ups have to comply with, the licensing process is still complex in many OECD countries. Many countries continue to make extensive use of licences and permits and do not have a "silence is consent" rule to speed up the administrative process. In addition, many countries still do not have one-stop shops that can provide businesses with information on all licences and permits, and, more importantly, that can issue all of them.

- Barriers in the service sectors surveyed (retail trade and professional services) are still relatively high in a large number of countries.

- Further progress could be made in reducing barriers to entry in domestic markets faced by foreign suppliers, in particular in retail trade and professional services.

12. The update of the sector PMR indicators also provides insights in the area of evaluation of regulations and reforms (Figure 2). Among OECD countries, there is a high degree of similarity in the regulation of network sectors (with the exception of the transport sector) and the gap vis-à-vis international best practice (represented by the value 0 ) is relatively small for most countries. In contrast, there is greater scope for removing unnecessary obstacles to competition in the regulatory set-up for retail distribution and professional services.

13. The 11 non-OECD countries included in this paper have in general a less competition-friendly regulatory stance than OECD countries, both at economy-wide and at sector level. However, there is considerable variety across them. In general, the five non-OECD countries that are members of the European Union tend to be closer to the OECD average, probably as a result of this membership, which requires regulatory convergence in a number of areas and sectors. 
Figure 1: Scope for improvement at the economy-wide level (OECD countries)

Indexes ranges from least (6) to most (0) competition-friendly regulation

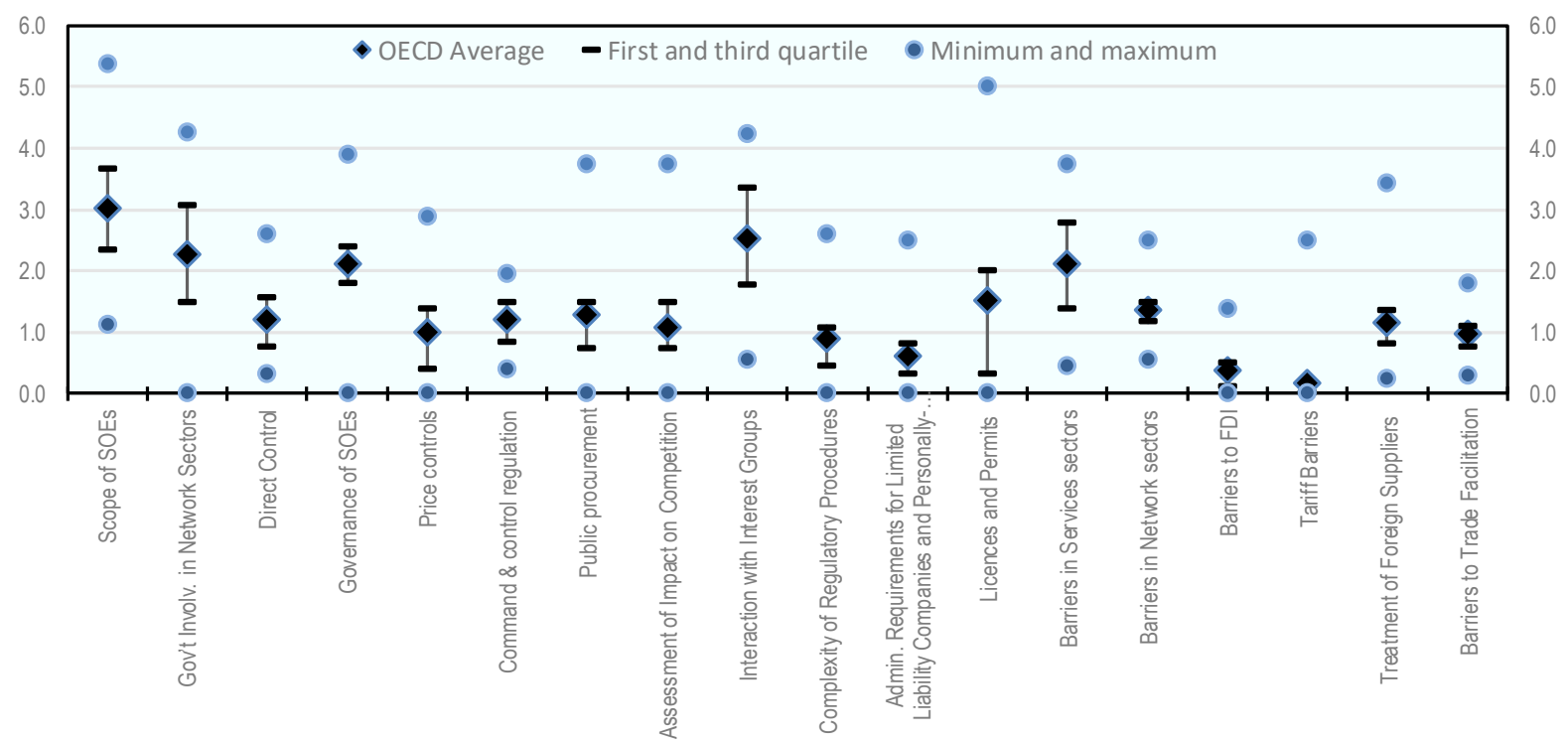

Note: For each sub-indicator in the figure, the diamond represents the OECD average and the vertical line represents the first and third quartile of the distribution of the values for OECD countries, while the blue dots represent the maximum and minimum values of the distribution. The US is the only OECD country not included, because the PMR data collection was not complete at the time of publication. Information refers to laws and regulation in force on 1 January 2018 and for a few countries 1 January 2019.

Source: OECD 2018 PMR database.

Figure 2: Scope for improvement at the sector level (OECD countries)

Indexes ranges from least (6) to most (0) competition-friendly regulation

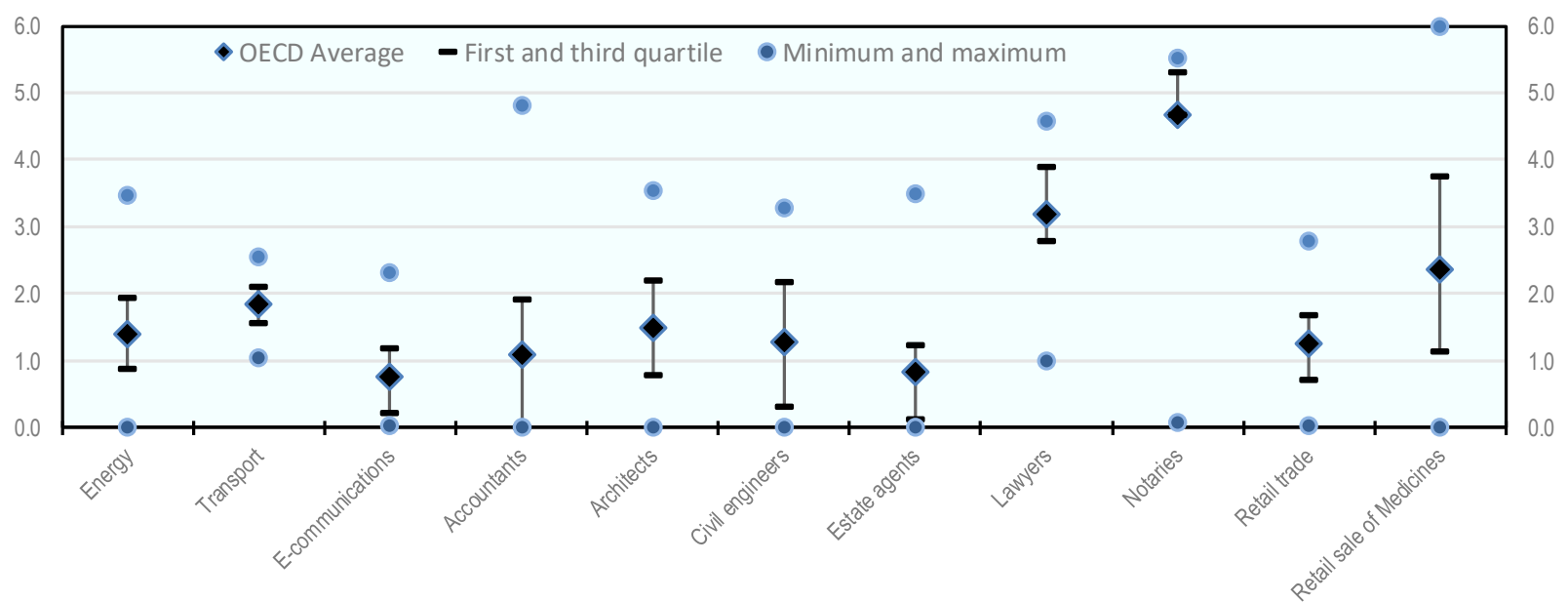

Note: For each sub-indicator in the figure, the diamond represents the OECD average and the vertical line represents the first and third quartile of the distribution of the values for OECD countries, while the blue dots represent the maximum and minimum values of the distribution. The US is the only OECD country not included, because the PMR data collection was not complete at the time of publication. Information refers to laws and regulation in force on 1 January 2018 and for a few countries 1 January 2019.

Source: OECD 2018 PMR database. 


\section{An outline of the PMR methodology}

\subsection{How PMR indicators are calculated}

14. The PMR indicators are based on an extensive database, which is compiled by the OECD relying on the answers of a questionnaire that is sent to national authorities. This database, which is available on the OECD PMR webpage ${ }^{3}$, contains a large amount of information on laws and regulations.

15. The questionnaire contains over 1400 questions on economy-wide and industry-specific regulatory provisions. All of these questions are closed questions that can be answered by selecting from a predefined menu (e.g. the question whether a specific regulation exists can be answered with 'yes' or 'no', or the question on the shares owned by the government in a company can be answered choosing a numerical value from a list).

16. The information included in the database is used to build two sets of indicators: an economy-wide indicator, which provides a general quantitative measure of a country's regulatory stance, and a group of sector indicators that measure the quality of regulation at the level of specific network and service sectors.

17. To calculate the indicators, the qualitative information is transformed into quantitative information by assigning a numerical value to each answer. This coding is based on accepted international best practices, which are summarised in the two 2018 PMR Schematas (available on the PMR webpage). The coded information is normalised over a zero to six scale, where a lower value reflects a more competitionfriendly regulatory stance. This information is then incorporated through a bottom-up approach into the two sets of indicators. This bottom-up approach permits to trace the indicators' scores back to individual policies.

18. The information refers to laws and regulations in force in the countries surveyed at a specific point in time. For most of the countries included in this paper, this date is 1 January 2018. However, for a few countries, namely Estonia, Bulgaria, Croatia, Costa Rica, Cyprus, Malta, and Romania, where the data collection was undertaken at a later stage, the information refers to laws and regulations in force on 1 January 2019.

19. The information used to build the PMR indicators only captures countries' "de jure" policy settings. This means that the answers are not based on 'subjective' assessments by market participants, and that they do not reflect the actual enforcement of the laws. These two factors make the indicators' comparability across countries more reliable by insulating them from context-specific assessments and by allowing the OECD to verify the reliability and precision of the answers. However, the "de jure" approach entails that the indicators do not reflect the extent and manner in which laws and regulations are enforced. Hence, a country that has laws "in the books" that are competition-friendly, but does not enforce them, would still obtain a favourable score.

20. A more detailed description of the PMR methodology can be found in the paper "2018 PMR indicators: the methodology", which is available on the PMR webpage (http://oe.cd/pmr).

\subsection{The 2018 economy-wide PMR indicator}

21. The economy-wide PMR indicator is constructed by aggregating the numerical values assigned to each question into 18 low-level indicators. These low-level indicators are then aggregated into six mid-

\footnotetext{
3 The new PMR webpage can be found at $h t t p: / / o e . c d / p m r$
} 
level indicators, which are in turn aggregated into two high-level indicators. The overall economy-wide indicator is the simple average across these two high-level indicators.

22. At each step of aggregation, the composite indicators are calculated as a simple average of their components.

23. Figure 3 below outlines the structure of the 2018 economy-wide indicator.

Figure 3. Structure of the 2018 PMR economy-wide indicator

\section{Product Market Regulation 2018}

\section{Distortions Induced by}

State Involvement

\section{Barriers to Domestic}

and Foreign Entry
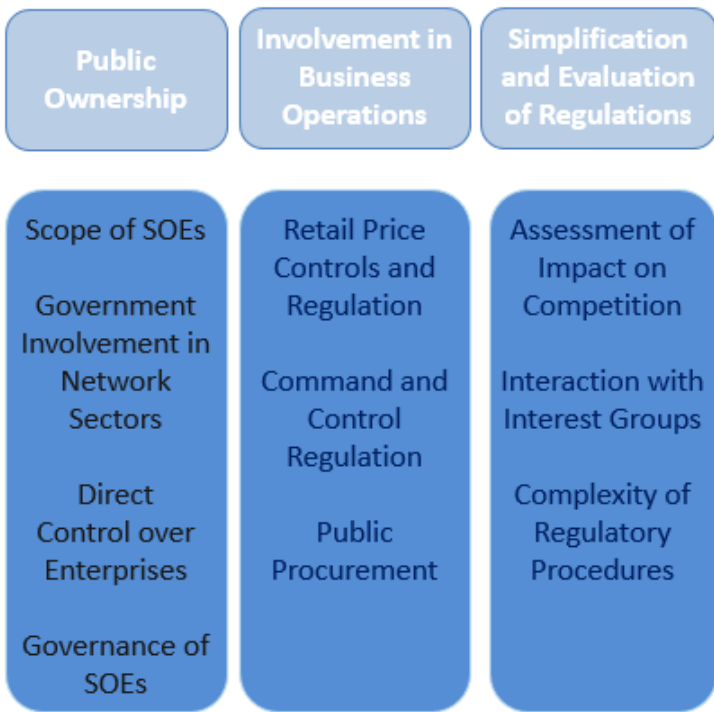
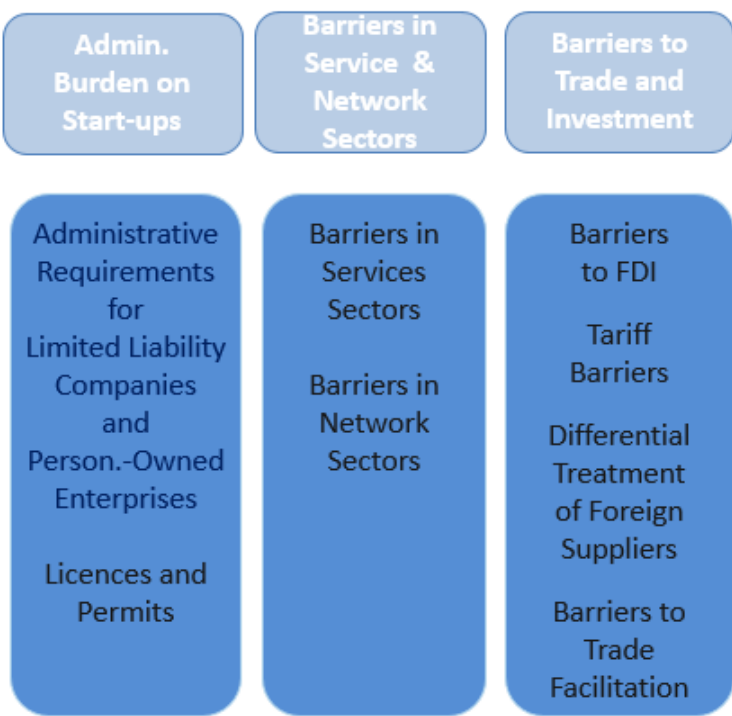

24. It is important to highlight that the structure shown in Figure 3 is different from the structure of the economy-wide PMR indicator used in previous vintages, because for the 2018 vintage the methodology for building this indicator has changed considerably.

25. These changes have affected the content of the economy-wide indicator, as well as its structure and the way the data is scored. These changes have been introduced to ensure that the PMR indicator maintains its relevance in the context of evolving insights from economy theory, modifications in the economic and business environment, technological change, and modifications in the practice of regulation.

26. Notably some new areas have been included, such as a horizontal area on the simplification and evaluation of regulations, and one on the regulatory framework for the public procurement of goods, services and public works. Most existing areas have also been revised and enriched with new questions (e.g. barriers in network and service sectors).

27. In addition, the structure of the indicator has also changed. The 2018 economy-wide indicator has moved to a two-legged structure, and the composition of the two high-level indicators is different from previous vintages. This new structure allows users to obtain a clearer distinction between regulations affecting competition through firm entry vis-à-vis other distortions to the level playing field. Further, it ensures that the structure is balanced, in terms of the information that is included in each leg, to avoid that 
certain aspects of the regulatory environment have a much greater weight compared to others in determining the value of the indicators.

28. Annex $\mathrm{C}$ provides more details on the changes introduced in the 2018 methodology.

\subsection{The 2018 sector PMR indicators}

29. The sector PMR indicators summarise information by sector, and not by regulatory domain as in the economy-wide indicator. These indicators cover three broad sectors: network industries, professional services and retail distribution.

30. The indicators for network sectors assess eight industries: electricity, natural gas, air transport, rail transport, road transport, water transport, as well as fixed and mobile e-communications. Each of these indicators is composed of information on how entry and conduct in the relevant sector is regulated, and on the level of public ownership.

31. These eight indicators are then aggregated into three indicators, one for each industry (energy, transport and e-communications), and in one single overall indicator covering all network sectors (Figure 4). It is important to stress that the overall indicator is an average of the eight disaggregated sector indicators, and not of the three industry ones. This approach is used to ensure that each of the eight sectors has the same weight in the overall indicator.

\section{Figure 4. Structure of the 2018 PMR indicators for Network Sectors}

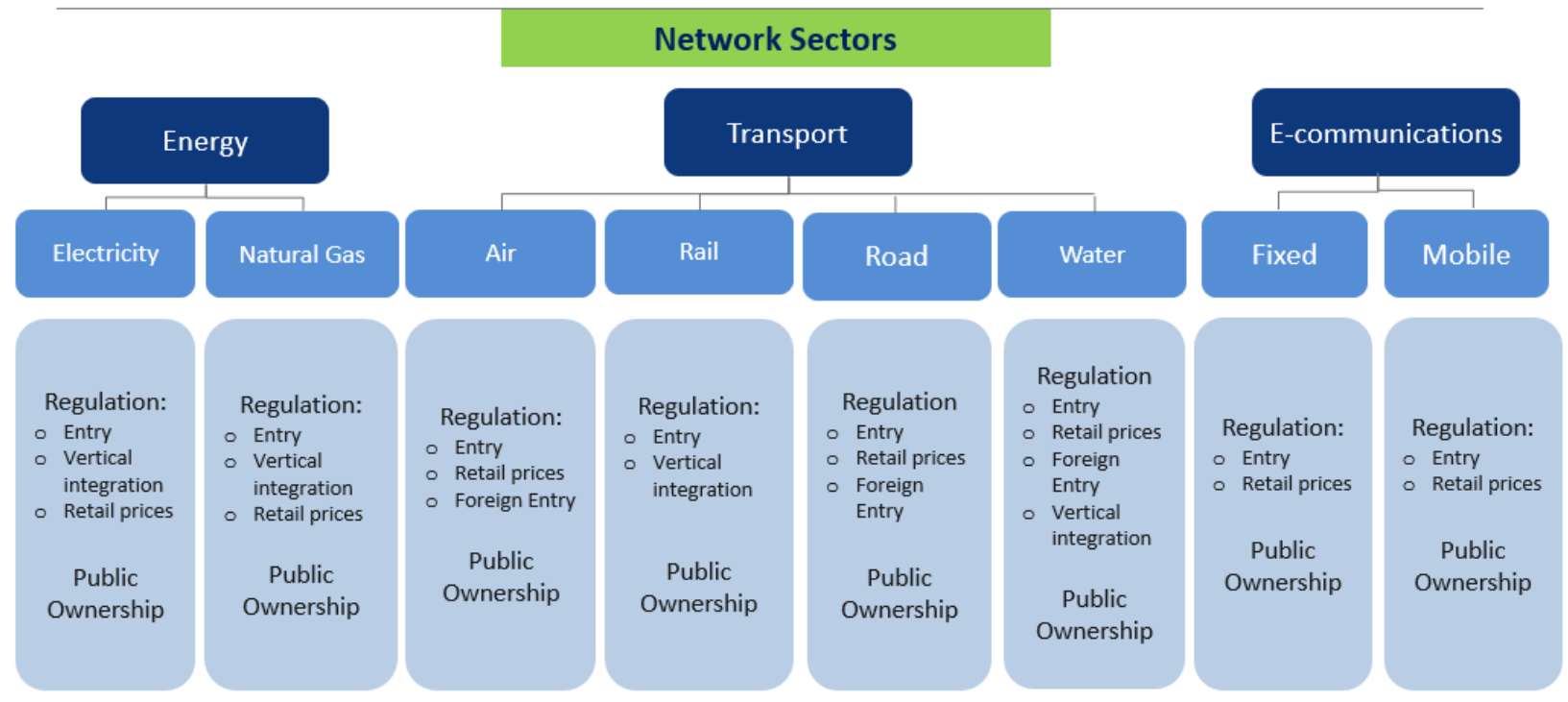

32. The service sector indicators cover six professions (accountants, architects, civil engineers, real estate agents, lawyers, and notaries), as well as two sectors in retail distribution (general retail trade and retail sales of medicines).

33. The professional services indicators cover information on entry requirements and conduct constraints (Figure.5), whereas the retail trade indicators covers a broad set of regulatory issues, ranging from shop opening hours to retail price regulation, and licensing (Figure 6).

34. There is no aggregate indicator covering all eight sectors given the very different nature of the sectors covered. In addition, there is no single indicator on the regulation of all professional services, because some professions do not exist in all countries and a single average would distort comparisons. 
Figure.5. Structure of the 2018 PMR indicators for Professional Services

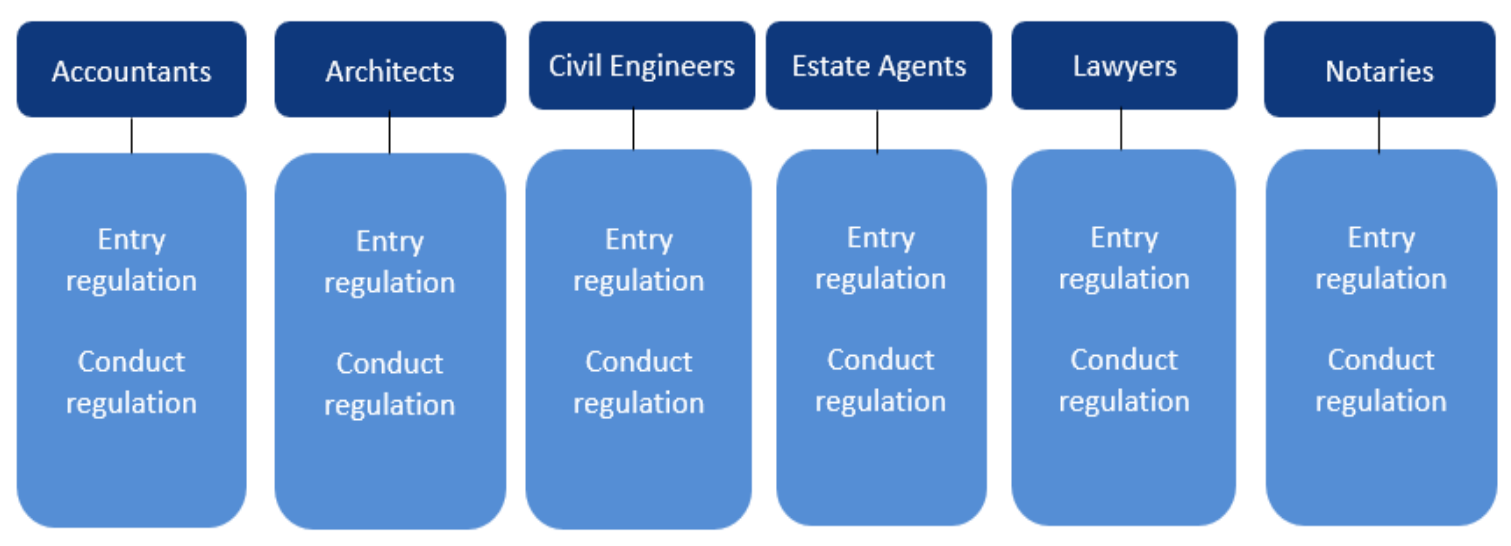

Figure 6. The structure of the 2018 PMR indicators for Retail Distribution

Panel A: General Retail Trade

\section{Retail Distribution}

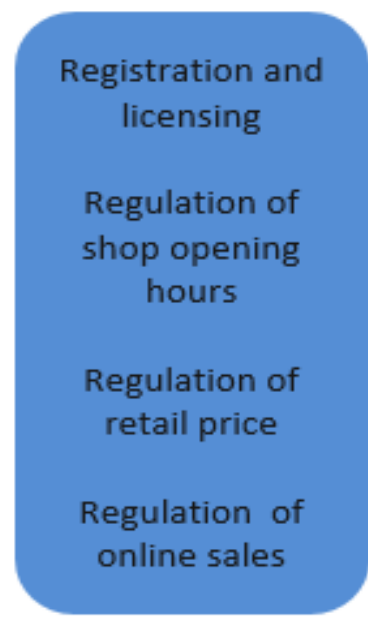

Panel B: Retail Sales of Medicines

\section{Retail Sale of Medicines}

Quantitative

Restrictions

Ownership

Restrictions

Regulation of opening hours

Regulation of sales outside pharmacies

Regulation of retail price

35. As for the economy-wide indicator, also the structure and content of the sector indicators have changed since the last PMR update in 2013. The most notable changes have been the inclusion of a new profession (real estate agents), the focus on individual professions rather than on groups of professions, which has led to the creation of two separate indicators for lawyers and notaries, the addition of the retail sale of medicines in the service sectors, and the removal of postal services.

36. Again, this implies that the 2018 indicators cannot be compared with previous vintages. Annex C provides more details on the changes in the methodology for the sector indicators. 


\section{Product market regulation in 2018: the economy-wide regulatory stance}

37. This section presents the results of the 2018 PMR indicators for all the OECD member countries, except the United States for which the data collection had not yet been completed at the time of publication, and for 11 non-OECD countries, namely: Argentina, Brazil, Bulgaria, Colombia, Costa Rica, Croatia, Cyprus, Kazakhstan, Malta, Romania and South Africa.

38. More non-OECD countries are being surveyed, but the data collection and assessment process is not yet complete. The OECD will publish the results of the PMR indicators for these countries on the PMR webpage, as they will be ready.

39. The completion rate of the 2018 vintage of the PMR database (i.e. the number of non-missing values as a proportion of the total number of questions) is extremely high (above $90 \%$ ) across all countries. A very close cooperation between national authorities and the OECD has ensured that the questionnaire has been filled almost entirely. The limited number of "missing answers" are mostly due to the fact that in some countries specific sectors or segments of sectors do not exist (e.g. there is no rail sector in Iceland, or there is no gas production in Switzerland). Only in very few cases, answers are genuinely missing.

\subsection{The current economy-wide regulatory stance at aggregate level}

40. The results indicate that a majority of OECD countries have an overall regulatory stance that is not far from international best practice, as measured by the average of the 5 best performing OECD countries (Figure 7). This is supported by the fact that the latter is not much lower than the OECD average (OECD average (1.38) and average of the 5 best performing OECD countries (1.00)), and that the variance is extremely small (0.07).

41. The results are different for the non-OECD countries currently included in the dataset. Their values are all above the OECD average ${ }^{4}$, indicating these countries have significantly greater scope to align their regulatory settings with best practices. However, among these countries there is considerable variation, as Croatia and Malta are very close to the OECD average, while Argentina and Brazil have the highest PMR values (2.65 and 2.58 respectively) currently in the database.

\footnotetext{
${ }^{4}$ No separate average is calculated for the non-OECD countries because the current sample of non-member countries is too small.
} 
Figure 7. The economy-wide PMR indicator in 2018

Countries ranked in ascending order from most (0) to least (6) competition friendly

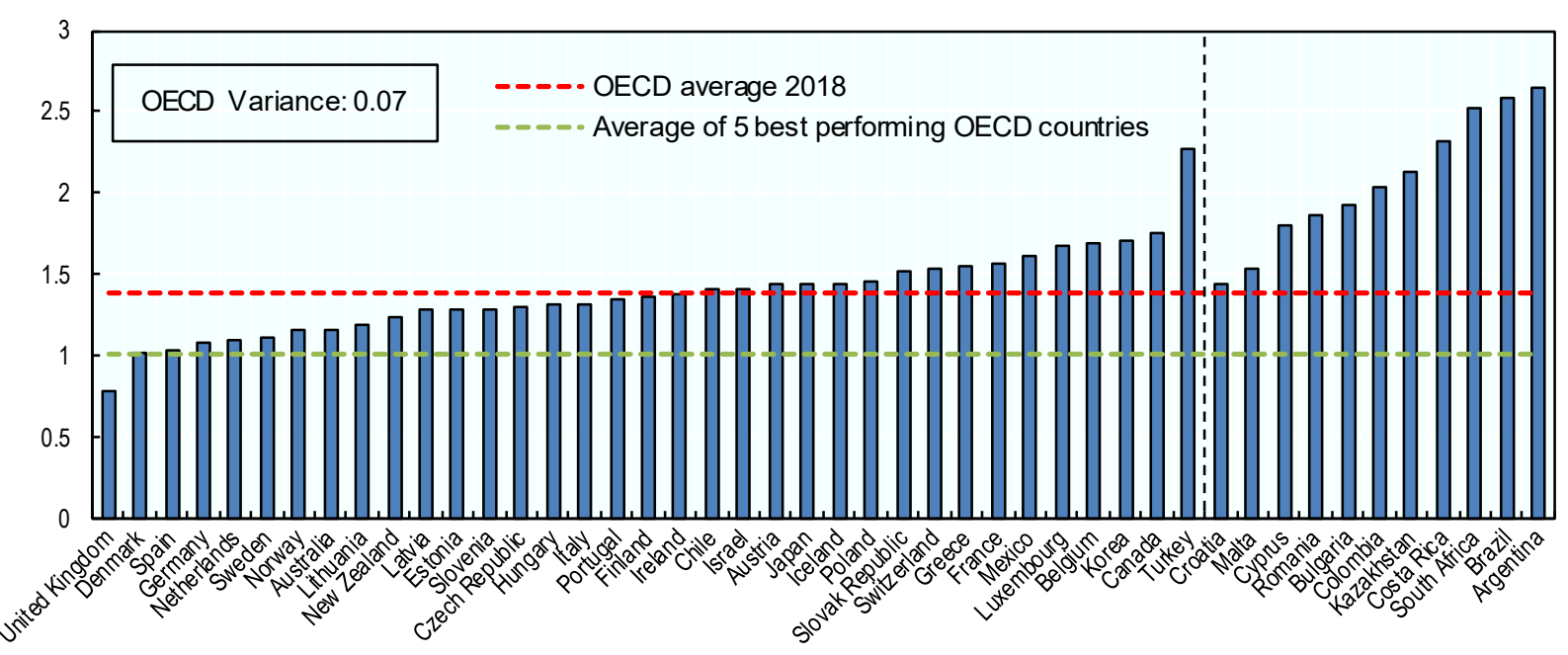

Note: A vertical dotted line divides the countries in two groups: before the line the OECD countries and after the non-OECD ones. The horizontal red dotted line represents the OECD average and the green one the average of the five countries with the most competition-friendly regulatory environment. If a bar does not appear on the chart, it means that its value is 0 . The US is the only OECD country not included in the OECD averages, because the PMR data collection was not complete at the time of publication. Information refers to laws and regulations in force on 1 January 2018 and for a few countries 1 January 2019.

Source: OECD 2018 PMR database.

42. Quantitative indicators are prone to aggregation errors, which reflect uncertainty regarding the appropriate weighting scheme of different lower level indicators. To provide a sense of the sensitivity of PMR values to the application of different sets of weights, Figure 8 shows the values of the economy-wide indicator within $90 \%$ confidence intervals that reflect the application of these different sets of weights. Box 1 explains the approach used to build this figure.

43. This exercise shows that the choice of weights used in building the indicators has a limited impact on the overall result. 


\section{Figure 8. The economy-wide PMR indicator in 2018 (random weights analysis)}

Countries ranked in ascending order from most (0) to least (6) competition friendly

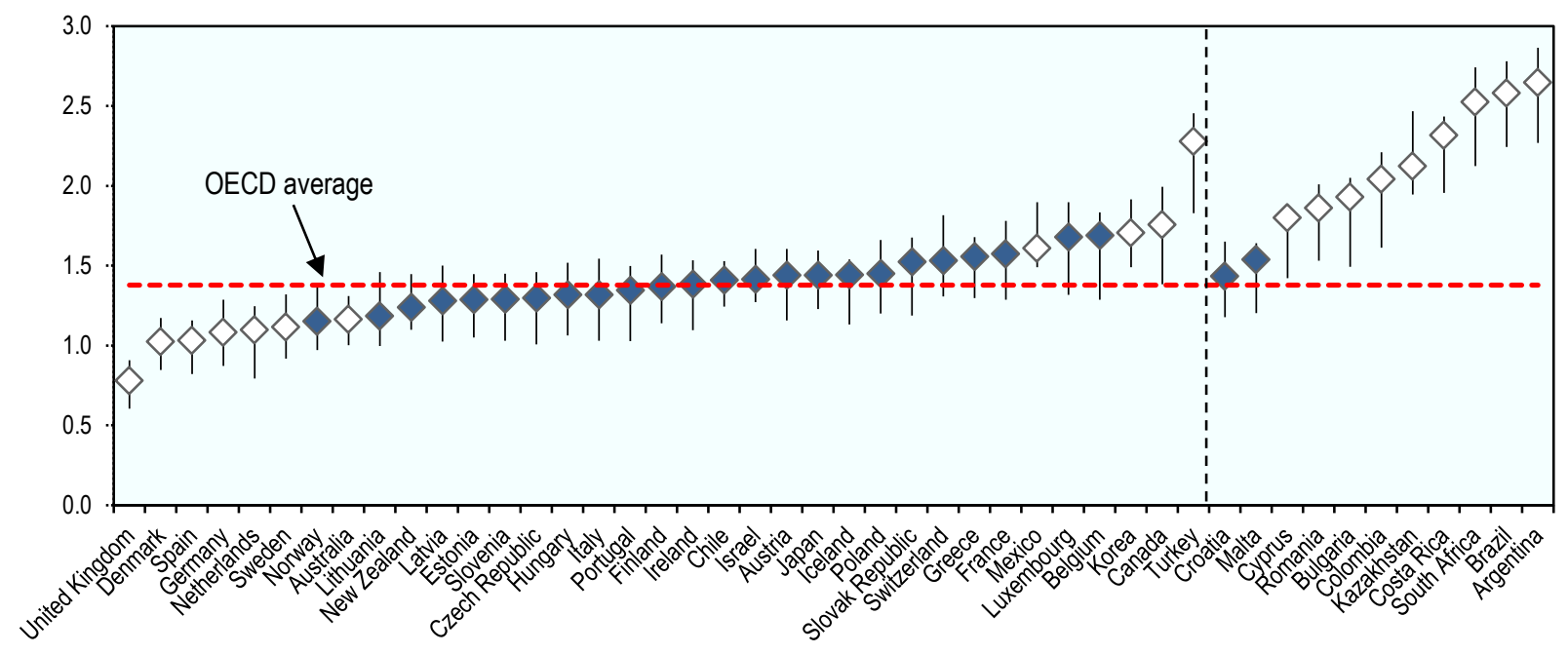

Note: A vertical dotted line divides the countries in two groups: before the line the OECD countries and after the non-OECD ones. Diamonds represent the indicator values built with equal weights at each step of the aggregation, which is the standard approach used to calculate the PMR indicators, and the vertical lines represent the 90\% confidence intervals derived from the random weights analysis. When this $90 \%$ confidence interval does not include the OECD average, the country is marked with a white diamond. These countries are usually those that have the most or the least competition friendly regulatory set-ups. When the $90 \%$ confidence interval includes the OECD average, the country is marked with a blue diamond. The horizontal red dotted line represents the OECD average. The US is the only OECD country not included in the OECD average, because the PMR data collection was not complete at the time of publication. Information refers to laws and regulations in force on 1 January 2018 and for a few countries 1 January 2019.

Source: OECD 2018 PMR database.

44. Based on the results shown in Figure 8, OECD countries can be separated into three broad groups:

Group 1: Australia, Denmark, Germany, the Netherlands, Spain, Sweden, and the United Kingdom have product market regulations that are more competition-friendly than in the average OECD country. ${ }^{5}$

Group 2: Canada, Korea, Mexico, and Turkey have product market regulations that are less competition-friendly than in the average OECD country. ${ }^{6}$

Group 3: The remaining countries have a regulatory stance that is close to the OECD average, although to varying degrees according to the point estimates. The regulatory practices of the countries in this last group are sufficiently close to each other that their relative ranking has no real significance.

45. All the non-OECD countries, excluding Croatia and Malta, have product market regulations that are significantly less competition-friendly than in the average OECD country.

\footnotetext{
${ }^{5}$ As explained in the note under Figure 8, this conclusion is based on the fact that the $90 \%$ confidence intervals for these countries' PMR, which have been derived from the random weights analysis, are located entirely below the OECD average.

${ }^{6}$ As explained in the note under Figure 8, this conclusion is based on the fact that the $90 \%$ confidence intervals for these countries' PMR, which have been derived from the random weights analysis, are located entirely above the OECD average.
} 


\section{Box 1. The random weights analysis}

In theory, the weights used to aggregate the various lower-level components of the PMR indicator should reflect the relative importance of each lower-level indicator for market outcomes. In practice, the latter is unknown. Hence, the OECD has chosen to use a uniform distribution of weights for simplicity and transparency. This means that equal weights are used at each step of the aggregation (Figure below). However, it is possible that the aggregate indicator values and cross-country positions would be somewhat different if the OECD had applied an alternative weighting scheme.

\section{Aggregation process for the PMR economy-wide indicator}

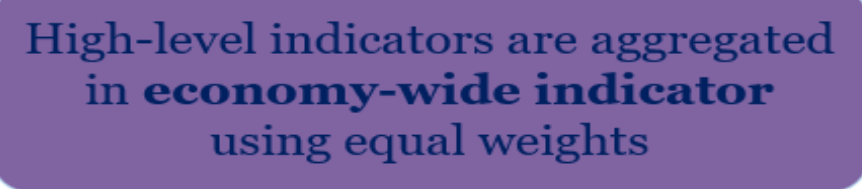

\section{Medium-level indicators are aggregated in 2 high level indicators using equal weights}

\section{Low-level indicators are aggregated in 6 medium level indicators using equal weights}

\section{Coded data is aggregated in 18 low level indicators using weights shown in PMR Schemata}

To investigate how sensitive the results of the indicators are to the choice of the weighting scheme used in the aggregation process, the OECD has generated a set of 10000 weights by randomly drawing them from a uniform distribution between zero and one and then normalising them so that they sum to one. This set of weights has then been used to aggregate the $18 \mathrm{low}$-level indicators into the two high-level indicators, thus generating 10000 pairs of values of the two high-level indicators.

The reason why the two high-level indicators are directly computed from the 18 low-level indicators is to avoid making assumptions about the nesting structure of the 6 mid-level indicators.

The overall PMR indicator is then computed as the simple average of each pair of the high-level indicators thus created, i.e. at the final step of aggregation, no randomisation is applied.

The reason why no randomisation is applied is that it would lead to very wide confidence intervals.

The distributions of values of the two high-level indicators and of the overall PMR indicators are then used to calculate $90 \%$ confidence intervals around the mean values, and thus determine how much the results depend on the original choice of uniform weights. 


\subsection{Going beyond the overall score}

46. The overall economy-wide PMR indicator is highly aggregated, as it incorporates in a single figure over 1000 data points. This means that the aggregation can hide much greater variation at the level of specific regulatory areas. Hence, it is necessary to look at the sub-components to obtain detailed information about countries' regulatory stance and to identify areas where improvements could be made (see again Figure 1 and Figure 2 above).

47. The economy-wide PMR indicator has two high-level components:

1. Distortions Induced by State Involvement, which captures the distortions that the involvement of the state in the economy can cause, and

2. Barriers to Domestic and Foreign Entry, which contains information on the level of the barriers to entry and expansion of domestic and foreign firms in various sectors of the economy.

48. In general, most OECD countries have a less competition-friendly regulatory stance in the area of Distortions induced by State Involvement than in the area of Barriers to Domestic and Foreign Entry. Indeed the OECD averages are respectively 1.60 and 1.16.

49. The relative position of the countries varies somewhat across the two high-level indicators. Nevertheless, there is a tendency for countries with a competition-friendly regulatory stance in one area, to have competition-friendly regulations in the other area. Indeed, the pair-wise correlations between the two high-level indicators for all OECD and non-OECD countries surveyed is 0.68 .

50. The choice of aggregation weights has a limited impact on the overall result. The $90 \%$ confidence intervals around the average PMR score, which reflect the sensitivity of these values to the application of different sets of weights, is wider than in the case of the aggregate indicator, but remain relatively narrow (Figure 9 and Figure 10). 
Figure 9. Distortions induced by State Involvement in 2018 (random weights analysis)

Countries ranked in ascending order from most (0) to least (6) competition friendly

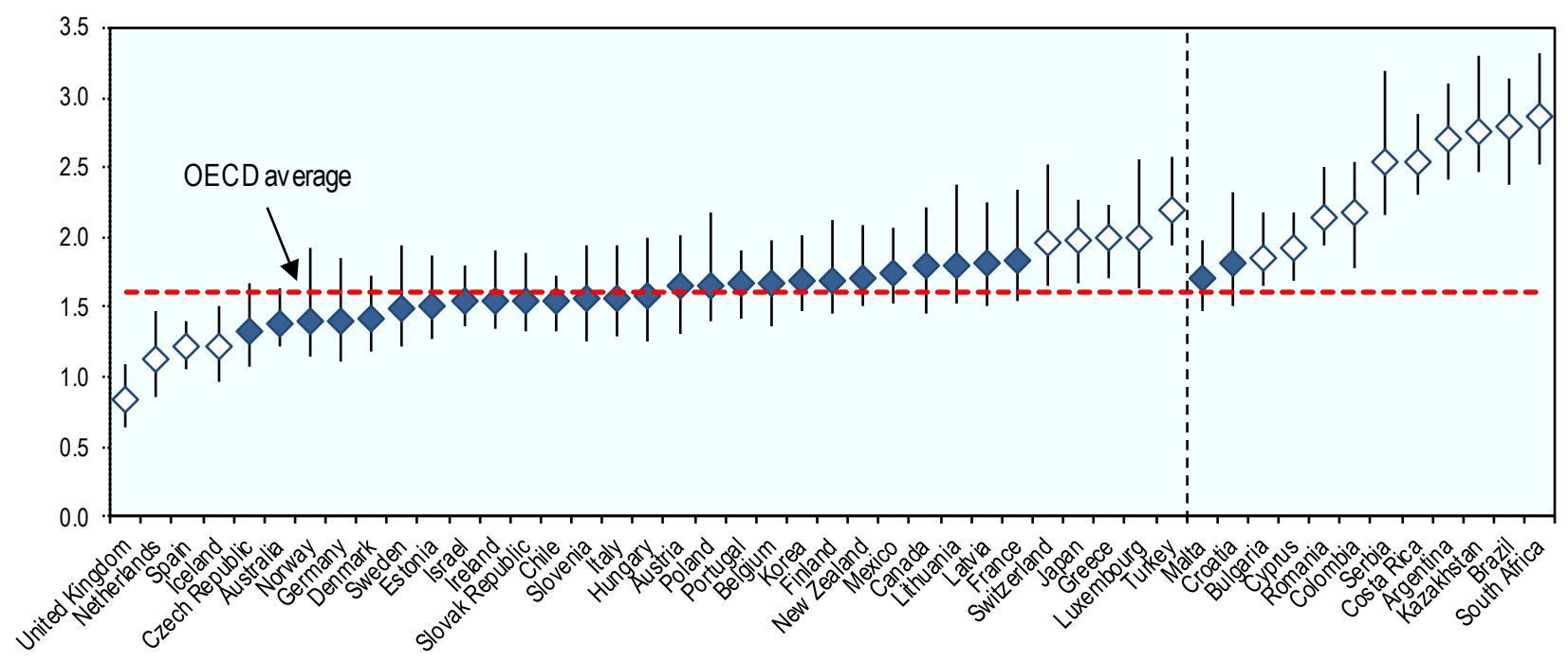

Note: A vertical dotted line divides the countries in two groups: before the line the OECD countries and after the non-OECD ones. Diamonds represent the indicator values built with equal weights at each step of the aggregation, which is the standard approach used to calculate the PMR indicators, and the vertical lines represent the $90 \%$ confidence intervals derived from the random weights analysis. White diamonds identify those countries whose the $90 \%$ confidence intervals do not include the OECD average. These countries are usually those that have the most or the least competition friendly regulatory set-ups. Blue diamonds, instead, identify those countries whose the $90 \%$ confidence intervals include the OECD average. The horizontal red dotted line represents the OECD average. The US is the only OECD country not included in the OECD average, because the PMR data collection was not complete at the time of publication. Information refers to laws and regulations in force on 1 January 2018 and for a few countries 1 January 2019.

Source: OECD 2018 PMR database. 
Figure 10. Barriers to Domestic and Foreign Entry in 2018 (random weights analysis)

Countries ranked in ascending order from most (0) to least (6) competition friendly

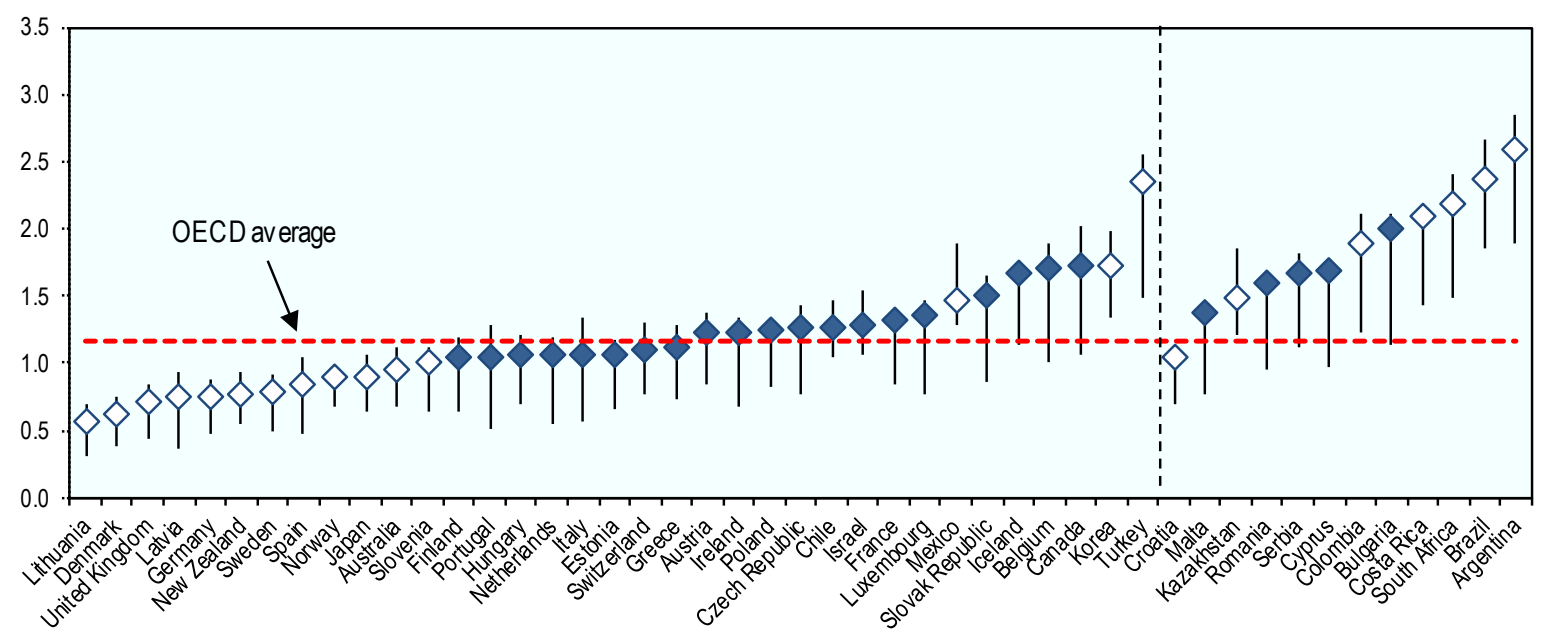

Note: A vertical dotted line divides the countries in two groups: before the line the OECD countries and after the non-OECD ones. Diamonds represent the indicator values built with equal weights at each step of the aggregation, which is the standard approach used to calculate the PMR indicators, and the vertical lines represent the $90 \%$ confidence intervals derived from the random weights analysis. White diamonds identify those countries whose the $90 \%$ confidence intervals do not include the OECD average. These countries are usually those that have the most or the least competition friendly regulatory set-ups. Blue diamonds, instead, identify those countries whose the $90 \%$ confidence intervals include the OECD average. The horizontal red dotted line represents the OECD average. The US is the only OECD country not included in the OECD average, because the PMR data collection was not complete at the time of publication. Information refers to laws and regulations in force on 1 January 2018 and for a few countries 1 January 2019.

Source: OECD 2018 PMR database - information refers to laws and regulations in force on 1 January 2018 and for a few countries 1 January 2019.

\subsection{Detailed insights: the low-level indicators}

51. To better understand what drives the scores of the two high-level indicators and in turn of the economy-wide indicator, it is necessary to go further and examine the values of the low-level components of the economy-wide indicator, also called the low-level indicators.

\section{The low-level indicators included in Distortions Induced by State Involvement}

52. Figure 11 shows again the structure of this part of the economy-wide indicator. 


\section{Distortions Induced by State Involvement}

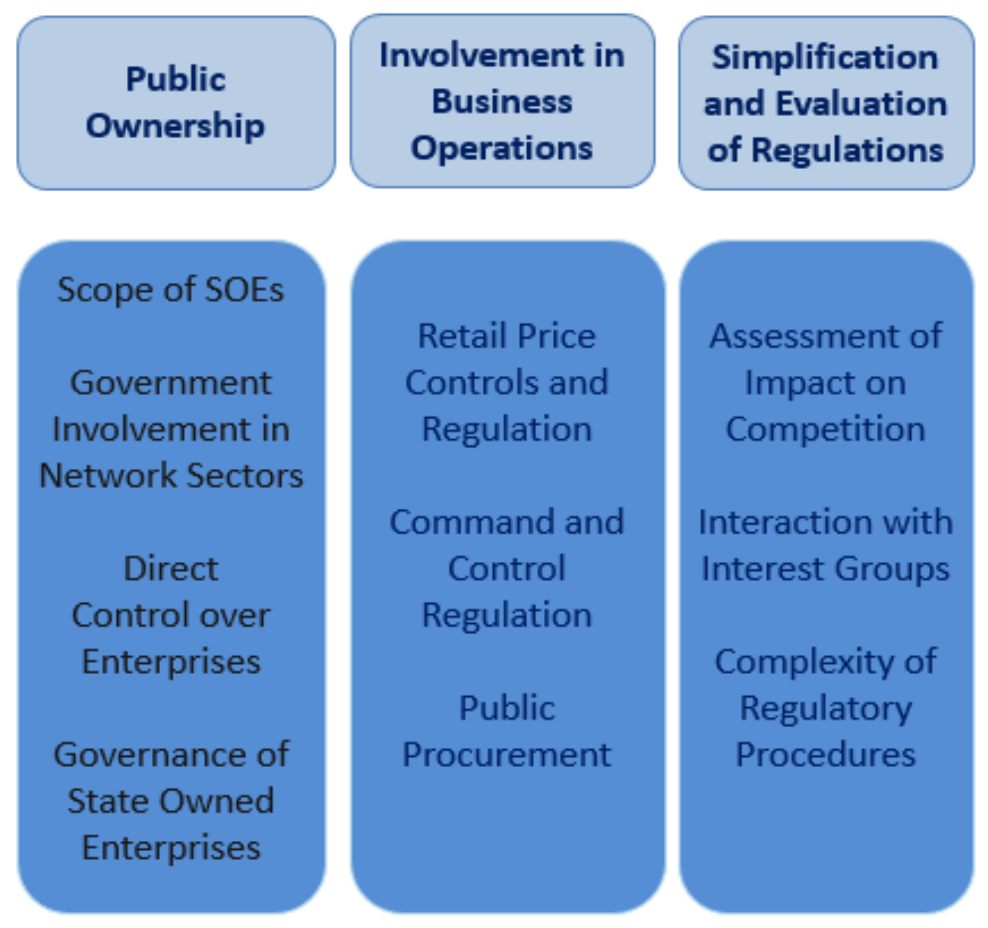

53. The first leg of the economy-wide PMR indicator Distortions Induced by State Involvement covers three key regulatory domains, represented by the three medium level indicators (the light blue boxes in Figure 11). These are:

1. Presence of state-owned enterprises in the economy and their governance (Public Ownership),

2. Controls and obligations imposed on private firms (e.g. price regulation) including the rules regulating the public procurement (Involvement in Business Operations), and

3. Rules in place to evaluate new and existing regulations in order to minimise negative impacts on competition and efforts in simplifying the administrative burden of interacting with the government (Simplification and Evaluation of Regulations).

54. The 10 low-level indicators (the dark blue boxes in Figure 11) focus each on a specific regulatory area, more specifically:

Scope of state-owned enterprises (SOEs): measures whether the government controls at least one firm in a number of business sectors, with a higher weight given to the key network sectors on which the PMR exercise focuses.

Direct control over business enterprises: measures the existence of special voting rights by the government in privately owned firms and constraints to the sale of government stakes in publicly controlled firms (based on same sectors and weights as the indicator above). 
Government involvement in network sectors: measures the size of the government's stake in the largest firm in key network sectors.

Governance of state-owned enterprises: measures the degree of insulation of state-owned enterprises from market discipline and degree of political interference in the management these firms.

Retail Price Controls: measures the extent and type of retail price controls in the key network and service sectors.

Command and control regulation: measures the extent to which the government uses coercive (as opposed to incentive-based) regulations across key network and service sectors.

Public procurement: measures the degree to which procurement rules ensure a level playing field in access to public contracts for the provision of goods, services and public works.

Assessment of Impact on Competition: measures the level of assessment of the impact of new and existing regulations on competition to ensure minimization of distortions to competition. About half of the information used in calculating this indicator is taken from the OECD iREG database ${ }^{7}$, which presents indepth evidence on countries' regulatory policy and governance practices.

Interaction with Interest Groups: measures the existence of rules for engaging stakeholders in the design of new regulation to reduce unnecessary restrictions to competition and for ensuring transparency of lobbying activities. Half of the information used in calculating this indicator is taken from the OECD iREG database.

Complexity of regulatory procedures: measures the government's efforts in reducing and simplifying the administrative burden of interacting with the government.

\section{What can the values of these low-level indicators tell us?}

55. The relatively high scores of the indicator Distortions induced by State Involvement (Figure 9 above) are primarily driven by the high level of public ownership of firms across the economy in many of the countries surveyed (captured in the low-level indicators Scope of SOEs and Government Involvement in Network Sectors). The quality of the rules aimed at ensuring that SOEs involved in commercial activities are fully exposed to market discipline (reflected in the low-level indicators Governance of SOEs) also plays a role in this result.

7 The iREG database presents in-depth evidence on countries' regulatory policy and governance practices in three areas: stakeholder engagement, regulatory impact assessment, and ex-post evaluation. For more information visit: $\mathrm{http} / / / \mathrm{www}$.oecd.org/gov/regulatory-policy/indicators-regulatory-policy-and-governance.htm. 


\section{4 | ECONKKP(2020)12}

56. The indicator on the Scope of SOEs, which captures if the government controls at least one firm in a number of sectors across the economy, is relatively high across the OECD, and is especially high in France, Lithuania, Luxembourg, Germany, Norway, Poland, and Switzerland (Figure 12). Moreover, many governments, both in OECD and non-OECD countries, hold a considerable number of shares in the major players in key network sectors, such as energy and e-communication (Figure 13). While it might be justified for governments to retain a certain level of participation in specific sectors, this indicator shows that there may be room for further reducing their presence in others.

\section{Figure 12. Low-level indicator on the Scope of SOEs in 2018}

Countries ranked in ascending order from most (0) to least (6) competition friendly.

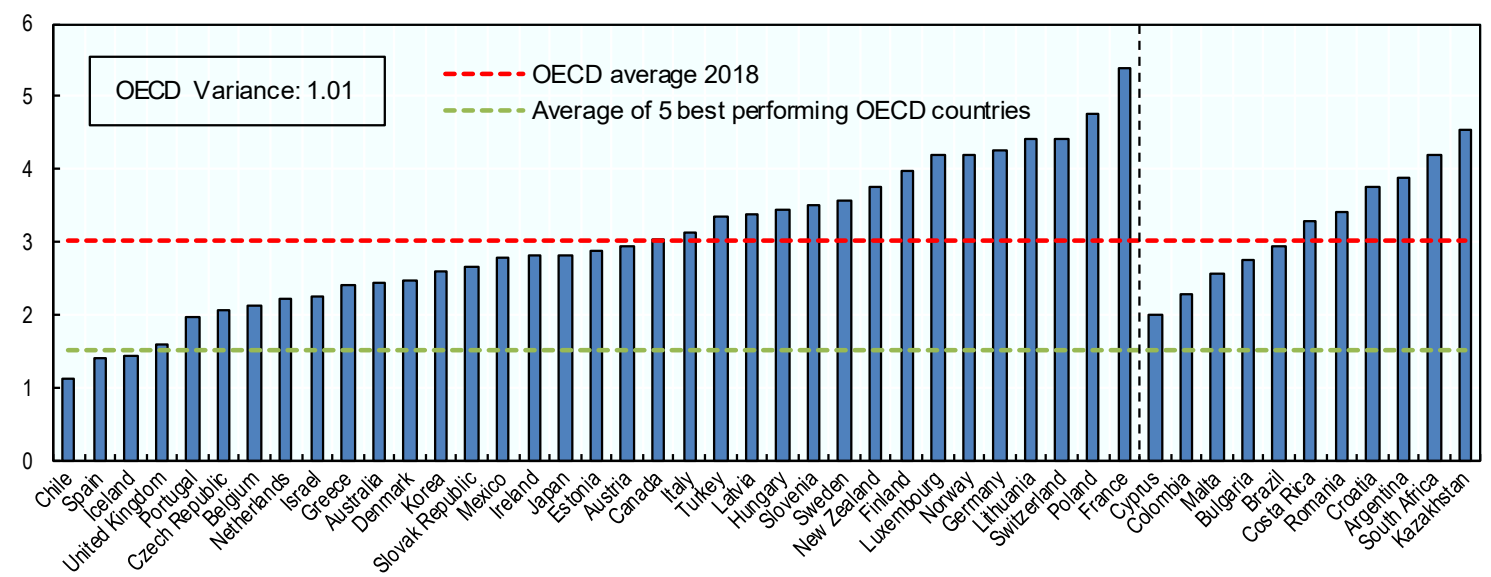

Note: A vertical dotted line divides the countries in two groups: before the line the OECD countries and after the non-OECD ones. The horizontal red dotted line represents the OECD average and the green one the average of the five countries with the most competition-friendly regulatory environment. If a bar does not appear on the chart, it means that its value is 0 . The US is the only OECD country not included in the OECD averages, because the PMR data collection was not complete at the time of publication. Information refers to laws and regulations in force on 1 January 2018 and for a few countries 1 January 2019.

Source: OECD 2018 PMR database. 


\section{Figure 13. Low-level indicator on Government Involvement in Network Sectors in 2018}

Countries ranked in ascending order from most (0) to least (6) competition friendly

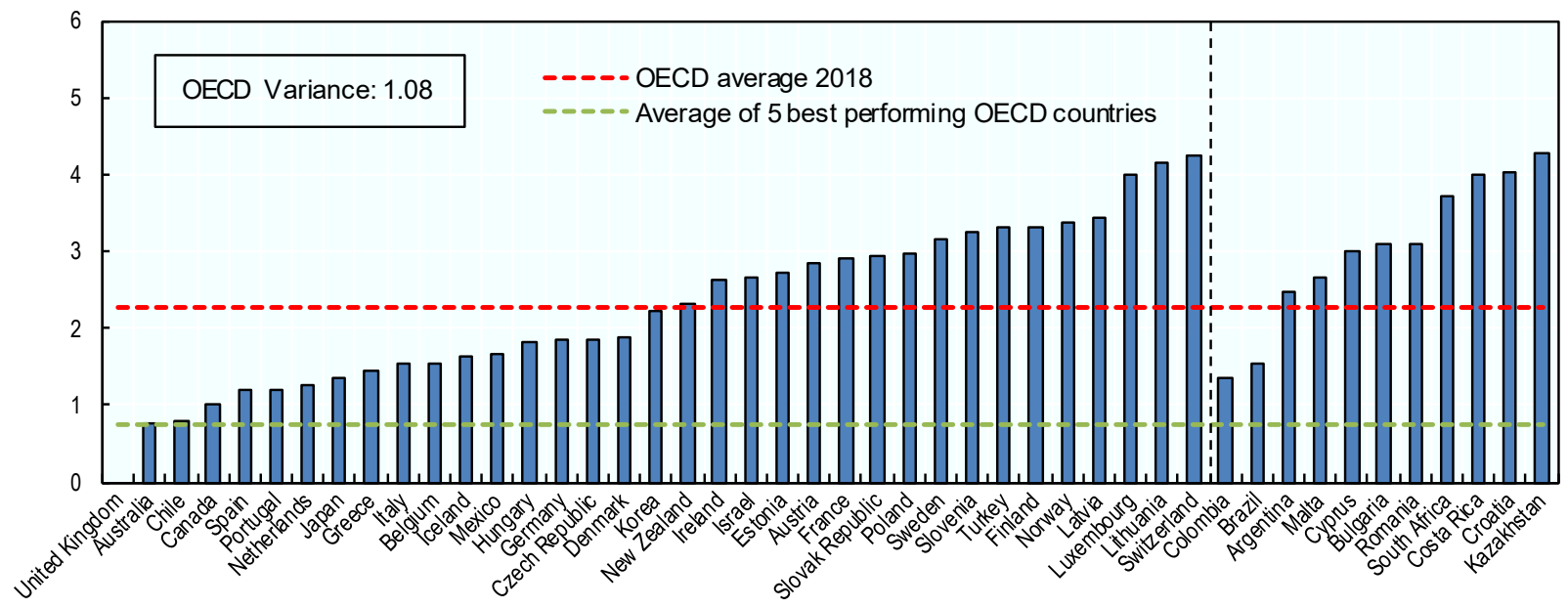

Note: A vertical dotted line divides the countries in two groups: before the line the OECD countries and after the non-OECD ones. The horizontal red dotted line represents the $O E C D$ average and the green one line the average of the five countries with the most competition-friendly regulatory environment. If a bar does not appear on the chart, it means that its value is 0 . The US is the only OECD country not included in the OECD averages, because the PMR data collection was not complete at the time of publication. Information refers to laws and regulations in force on 1 January 2018 and for a few countries 1 January 2019.

Source: OECD 2018 PMR database.

57. Further, several OECD countries are not fully aligned with key elements of the OECD's Guidelines on the corporate governance of SOEs, as shown by the values of the relevant indicator (Figure 14). These guidelines measure the extent to which practices regarding the management and regulation of SOEs that perform commercial activities, in competition or potentially in competition with privately owned firms ${ }^{8}$.

58. Greater risks of distortions to competition arise when state ownership is pervasive (high values in Figure 12) and the corporate governance of SOEs is distant from best practice (high values in Figure 14). In several countries, the governance of SOEs is not sufficiently strong to level the playing field between privately and publicly owned firms, while SOEs are present in many sectors of the economy. This is the case notably in in Canada, Lithuania, Luxembourg, Mexico, Poland, , Argentina, Costa Rica, Kazakhstan, Serbia, South Africa, and Romania ${ }^{9}$.

8 The 2015 OECD Guidelines on Corporate Governance of State-Owned Enterprises can be found at: https://www.oecd.org/corporate/quidelines-corporate-governance-soes.htm

This list has been generated by multiplying the values for the two low level indicators - Governance of SOEs and Scope of SOEs -and then dividing the result by 6 to rescale it. The outcome of these operation for all the countries herein examined have been ranked in descending order and the countries listed above are those with the ten highest values (Mexico and Luxembourg have the same values). 
Figure 14. Low-level indicator on Governance of SOEs in 2018

Countries ranked in ascending order from most (0) to least (6) competition friendly

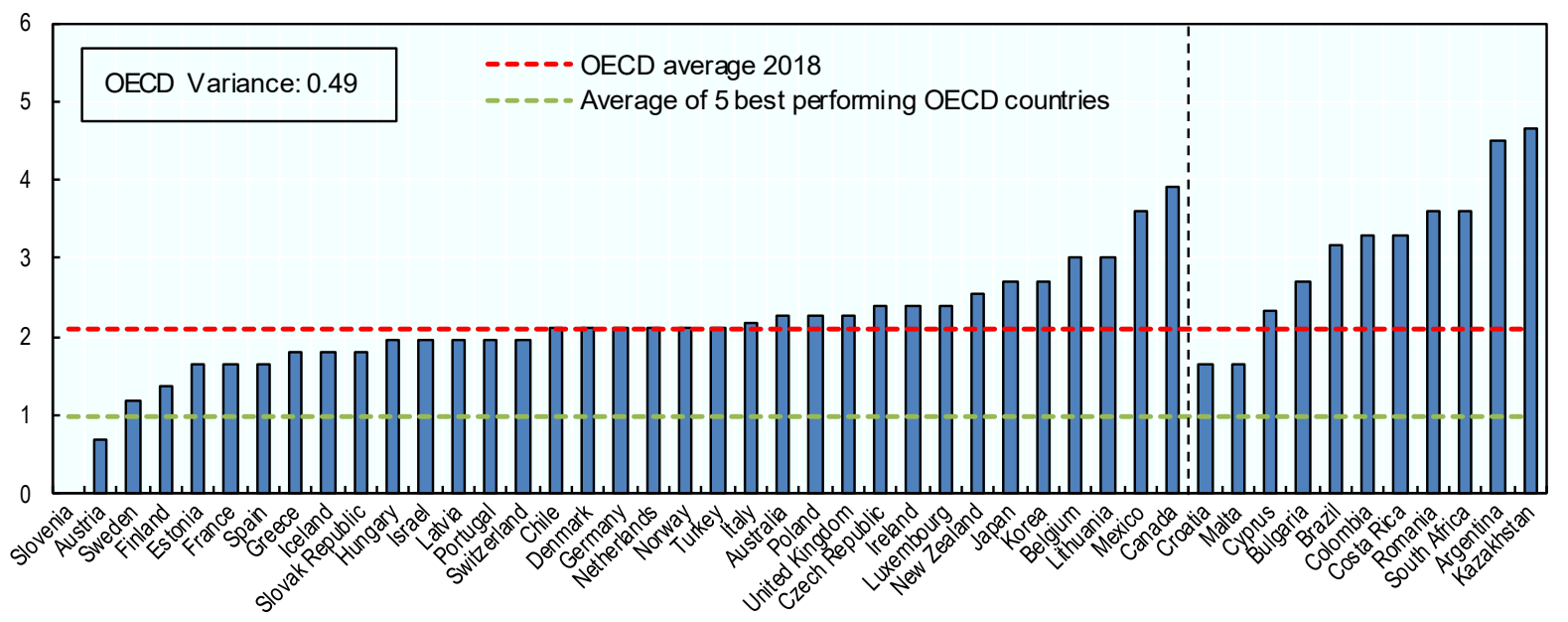

Note: A vertical dotted line divides the countries in two groups: before the line the OECD countries and after the non-OECD ones. The $r=$ horizontal red dotted line represents the OECD average and the green one the average of the five countries with the most competition-friendly regulatory environment. If a bar does not appear on the chart, it means that its value is 0 . The US is the only OECD country not included in the OECD averages, because the PMR data collection was not complete at the time of publication. Information refers to laws and regulations in force on 1 January 2018 and for a few countries 1 January 2019.

Source: OECD 2018 PMR database.

\section{Other low-level indicators included in Distortions induced by State Involvement}

59. On average, the other low-level indicators included in this element of the PMR have quite low values. Hence, below we discuss only those that have been introduced in this vintage of the PMR indicators for the first time. The values of all the low-level indicators can be found in Annex A.

60. Many countries appear to have aligned their framework for the public procurement of goods, services and public works with key best practices necessary to ensure a level playing field across potential participants to public procurement processes (Figure 15). However, a few countries stand out as having high values, in particular Canada, Japan, Israel ${ }^{10}$, Mexico, and Brazil.

61. It is important to stress that the PMR indicators measure the de jure situation, i.e. the quality of the law in the books, and do not consider to what extent countries effectively implement them. Public procurement is an area where the difference between de jure and de facto conditions can be important and countries with low values may nevertheless still not apply good public procurement practices.

10 The statistical data for Israel are supplied by and under the responsibility of the relevant Israeli authorities. The use of such data by the OECD is without prejudice to the status of the Golan Heights, East Jerusalem and Israeli settlements in the West Bank under the terms of international law. 


\section{Figure 15. Low-level indicator on Public Procurement in 2018}

Countries ranked in ascending order from most (0) to least (6) competition friendly

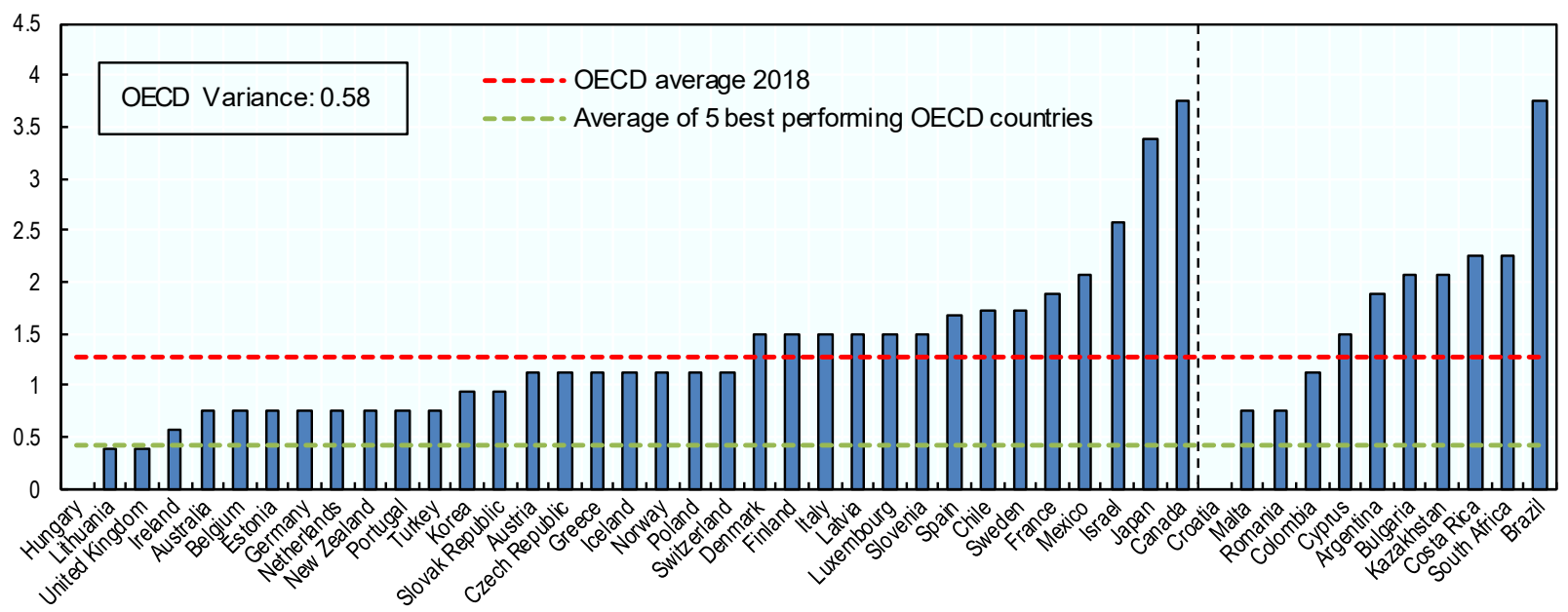

Note: A vertical dotted line divides the countries in two groups: before the line the OECD countries and after the non-OECD ones. The horizontal red dotted line represents the OECD average and the green one the average of the five countries with the most competition-friendly regulatory environment. If a bar does not appear on the chart, it means that its value is 0 . The US is the only OECD country not included in the OECD averages, because the PMR data collection was not complete at the time of publication. Information refers to laws and regulations in force on 1 January 2018 and for a few countries 1 January 2019.

Source: OECD 2018 PMR database.

62. Most countries, at least among OECD countries, have put in place mechanisms to consider the impact on competition of new laws and regulations (Figure 16). However, there are still some countries that could make improvements in this domain, for example by including the assessment of the impact on competition in regulatory impact assessments. In addition, several countries lack rules that require policymakers to take into account stakeholders' views, and many OECD countries do not require transparency and accountability in the interactions between public officials, in particular legislators, and interest groups (Figure 17). ${ }^{11}$ The lack of rules in this area may favour lobbying activities by incumbents and firms with greater resources, which can distort the regulatory design process at the expense of new entrants and smaller firms.

11 About half of the information used in calculating Assessment of the Impact on Competition and Interaction with Interest Groups comes from the OECD iREG database. This database can be a useful source of information to better interpret this element of the PMR indicators. 
Figure 16. Low-level indicator on the Assessment of Impact on Competition in 2018

Countries ranked in ascending order from most (0) to least (6) competition friendly

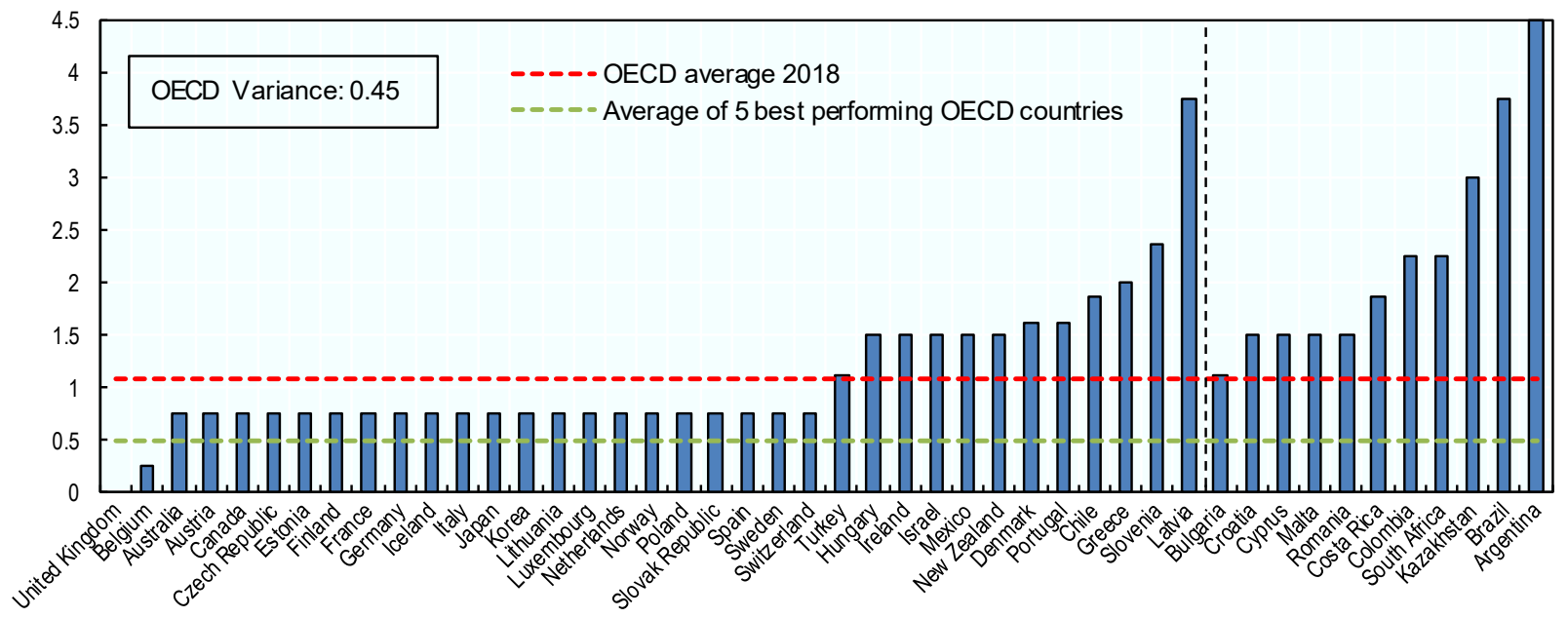

Note: A vertical dotted line divides the countries in two groups: before the line the OECD countries and after the non-OECD ones. The horizontal red dotted line represents the OECD average and the green one the average of the five countries with the most competition-friendly regulatory environment. If a bar does not appear on the chart, it means that its value is 0 . The US is the only OECD country not included in the OECD averages, because the PMR data collection was not complete at the time of publication. Information refers to laws and regulations in force on 1 January 2018 and for a few countries 1 January 2019.

Source: OECD 2018 PMR database.

Figure 17. Low-level indicator on the Interaction with Interest Groups in 2018

Countries ranked in ascending order from most (0) to least (6) competition friendly

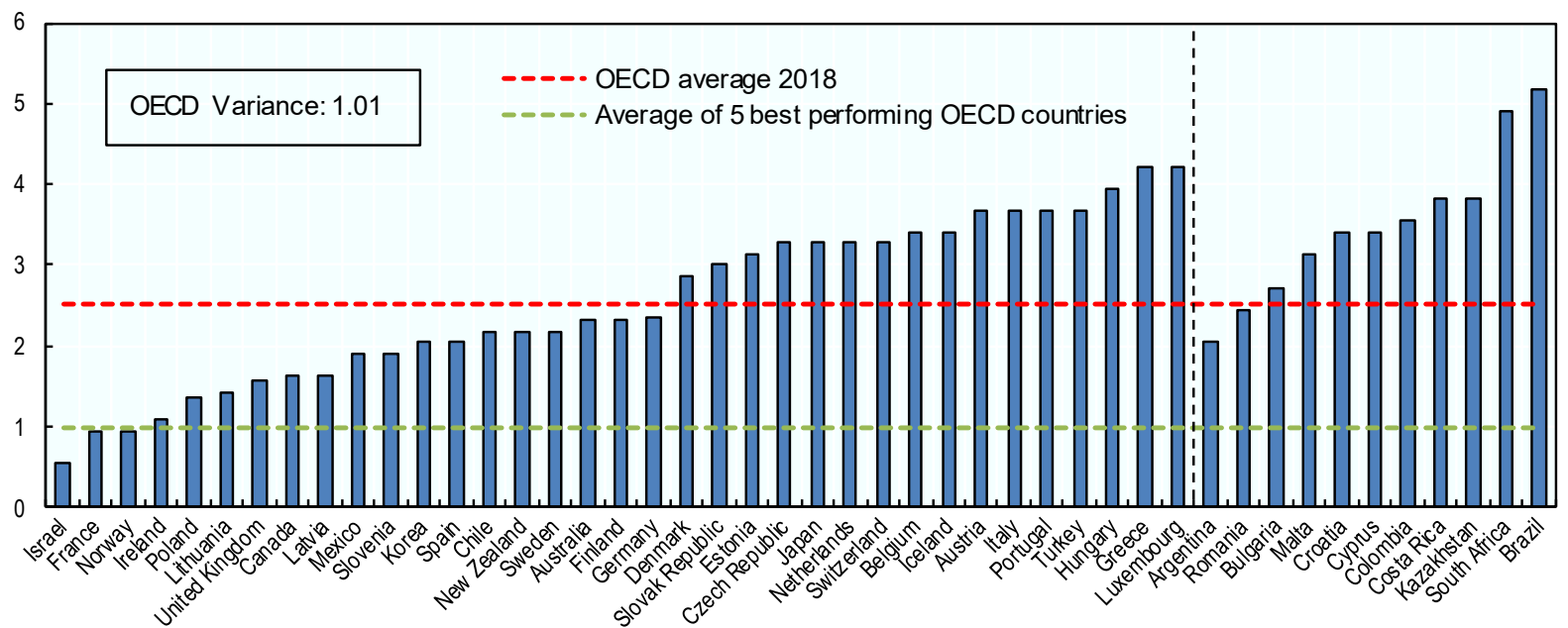

Note: A vertical dotted line divides the countries in two groups: before the line the OECD countries and after the non-OECD ones. The horizontal red dotted line represents the OECD average and the green one the average of the five countries with the most competition-friendly regulatory environment. If a bar does not appear on the chart, it means that its value is 0 . The US is the only OECD country not included in the OECD averages, because the PMR data collection was not complete at the time of publication. Information refers to laws and regulations in force on 1 January 2018 and for a few countries 1 January 2019.

Source: OECD 2018 PMR database. 


\section{The lower level indicators included in Barriers to Domestic and Foreign Entry}

63. Turning to the low-level indicators included in the second leg of the economy-wide PMR indicator - Barriers to Domestic and Foreign Entry, Figure 18 shows again the structure of this part of the economywide indicator.

Figure 18. Composition of the high-level indicator: Barriers to Domestic and Foreign Entry

\section{Barriers to Domestic and}

Foreign Entry
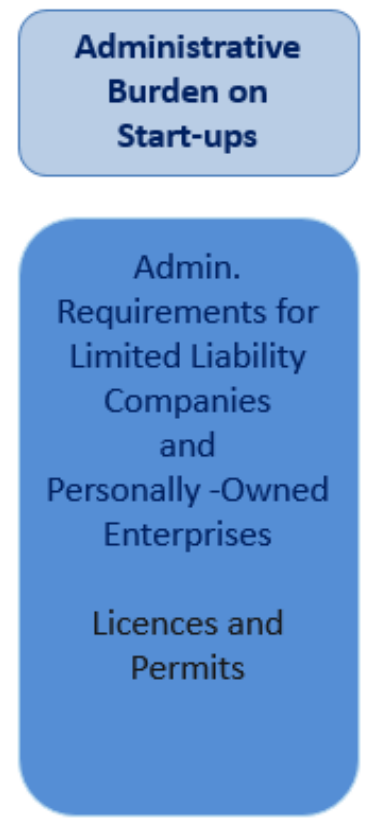
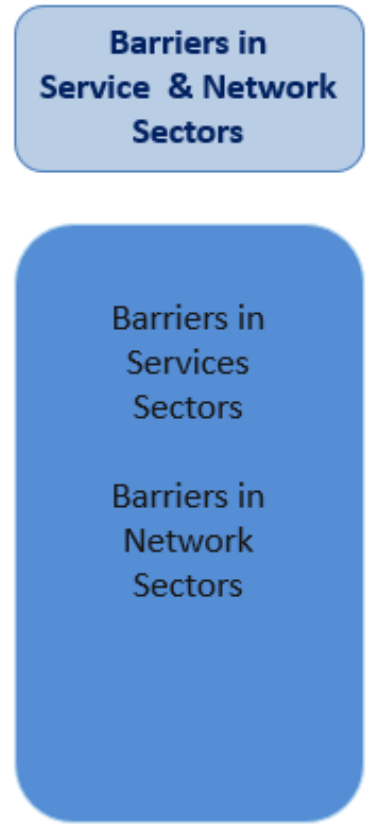

Barriers to Trade and Investment

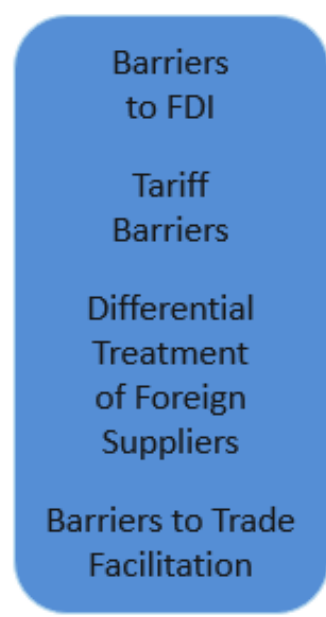

64. The second leg of the economy-wide PMR indicator Barriers to Domestic and Foreign Entry covers three key regulatory domains represented by the three medium level indicators (the light blue boxes in Figure 18). These are:

1. The administrative burden that new firms have to face to start their business (Administrative Burden on Start-ups),

2. The qualitative and quantitative barriers firms face when entering and operating in specific key economic sectors (Barriers in Service and Network Sectors),

3. The barriers that could limit the access to domestic markets of foreign firms and foreign investors (Barriers to Trade and Investment).

65. The 8 low-level indicators (the dark blue boxes in Figure 18) focus each on a specific regulatory area, more specifically:

Administrative Requirements for limited liability companies and personally owned enterprises: measures the extent of the administrative requirements necessary to set up new enterprises, with a focus on two specific legal forms: limited liability companies and personally owned enterprises. 


\section{0 | $\operatorname{ECO} / \mathrm{WKP}(2020) 12$}

Licences and permits: measures the existence of initiatives to simplify licensing procedures, such as 'onestop-shops' for informing business about licences and notifications and for issuing/accepting them, 'silence is consent' rule and programs to review and reduce number of licences.

Barriers in services sectors: measures the extent of the qualitative and quantitative barriers to competition arising from existing regulation in key service sectors ${ }^{12}$.

Barriers in network sectors: measures the extent of the qualitative and quantitative barriers to competition arising from existing incentive-based regulation in network sectors ${ }^{13}$.

Differential treatment of foreign suppliers: measures the level of discrimination that foreign firms may experience when participating in public procurement processes, and the barriers to entry that foreign firms may experience sectors relative to domestic firms in key network and service.

Barriers to Foreign Direct Investment (FDI): measures the restrictiveness of a country's FDI rules in 22 sectors in terms of foreign equity limitations, screening or approval mechanisms, restrictions on the employment of foreigners as key personnel and operational restrictions. This indicator reflects the value of the FDI Restrictiveness Index developed by the OECD Directorate for Financial and Enterprise Affairs. ${ }^{14}$

Tariff barriers: reflect the value of a cross-product average of effectively applied tariffs. The source of the relevant information is the UNCTAD Trade Analysis Information System database. ${ }^{15}$

Barriers to trade facilitation: measures the level of complexity of the technical and legal procedures for international trade, ranging from border procedures to the simplification and harmonisation of trade documents. This indicator reflects the value of the average of a subset of the Trade Facilitation Indicators developed by the OECD Trade and Agricultural Department. ${ }^{16}$

\section{What can the values of these low-level indicators tell us?}

66. In general, the regulatory stance in OECD countries in the area of Barriers to Domestic and Foreign Entry component is competition friendly (i.e. the OECD average is 1.16). However, a more in depth look at the components of the indicator reveals a more complex situation. The amount of administrative requirements on new firms is in general quite low, but the process for granting licences and permits is still complex in many countries and there are barriers to the entry and expansion of firms in service sectors and, to a lesser extent, in network sectors. Further, while the overall barriers to trade and investment are rather low, the same is not true when one considers barriers to entry for foreign suppliers in public tenders or in the service sector. Results are less positive and more varied for non-OECD countries. Below we

12 This indicator captures the barriers to competition that can exist in service sectors that are related to incentivebased regulation. The sub-indicator Command and Control Regulation measures the barriers created by the government's use of coercive regulations in the same sectors.

13 This indicator captures the barriers to competition that can exist in network sectors that are related to incentive-based regulation. The sub-indicator Command and Control Regulation measures the barriers created by the government's use of coercive regulations in the same sectors.

14 More information on the FDI restrictiveness index can be found at

http://www.oecd.org/investment/fdiindex.htm. For the few countries outside the OECD for which this Index is not exist, calculated an average of the values for other countries is used. For more details, please refer to the 2018 PMR schemata (available on the PMR website).

15 The UNCTAD Trade Analysis Information System database can be accessed at https://wits.worldbank.org/

16 More information on the OECD Trade Facilitation Indicators can be found at

http://www.oecd.org/trade/topics/trade-facilitation/ 
present the results for the most relevant low-level indicators in this area. See Annex A for a complete reporting of the values of all low-level indicators.

67. The indicator on Administrative Requirements for Limited Liability Companies and Personally Owned Enterprises (Figure 19) includes information on the requirements that need to be complied with to start up a new firm and the number of bodies that have to be contacted to complete them. It focuses on two legal forms, which usually are the most commonly adopted by start-ups. The first is personally owned enterprises, which are business entities that are owned and run by one natural person and in which there is no legal distinction between the owner and the business. The second is limited liability companies that are not quoted on the stock market.

68. The values for this indicator are very low for most OECD countries, in some cases even close to zero. On the contrary, most of the non-OECD countries in the sample still impose burdensome procedures on start-ups.

Figure 19. Low-level indicator on Administrative Requirements for Limited Liability Companies and Personally Owned Enterprises in 2018

Countries ranked in ascending order from most (0) to least (6) competition friendly

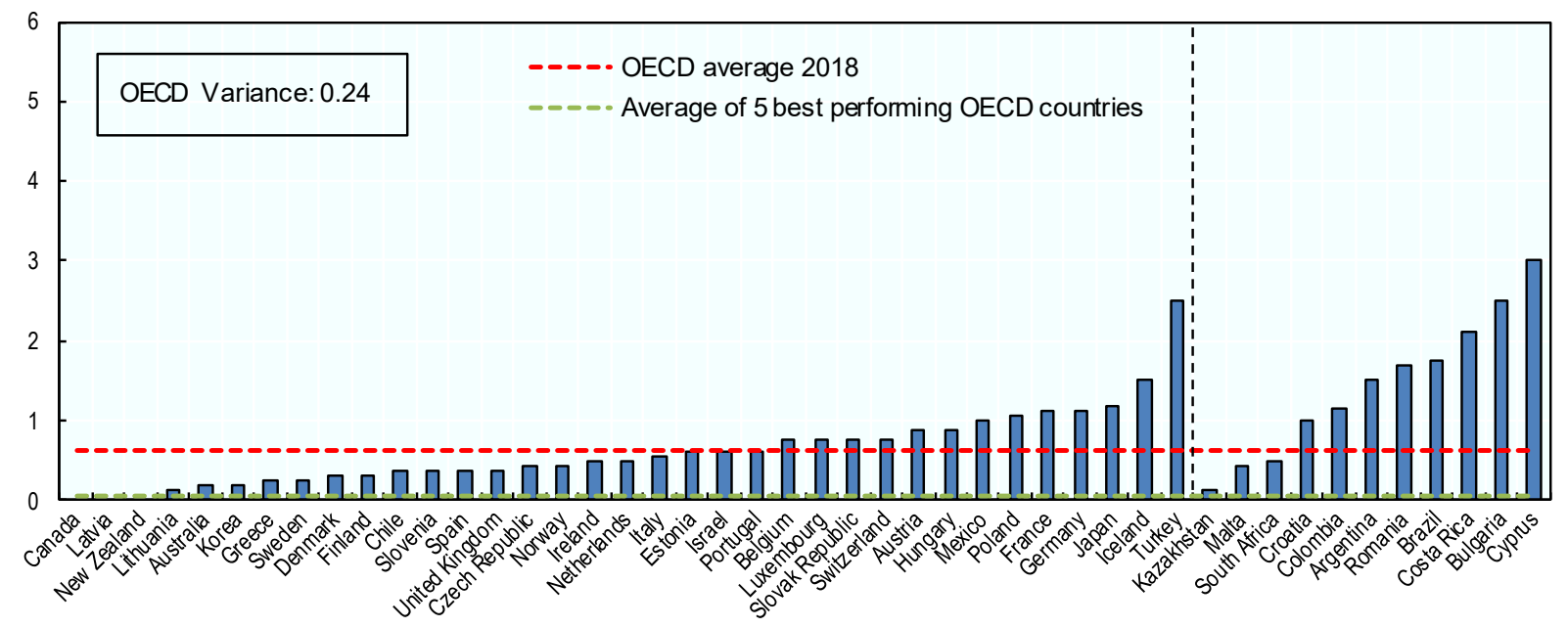

Note: A vertical dotted line divides the countries in two groups: before the line the OECD countries and after the non-OECD ones. The horizontal red dotted line represents the OECD average and the green one the average of the five countries with the most competition-friendly regulatory environment. If a bar does not appear on the chart, it means that its value is 0 . The US is the only OECD country not included in the OECD averages, because the PMR data collection was not complete at the time of publication. Information refers to laws and regulations in force on 1 January 2018 and for a few countries 1 January 2019. Source: OECD 2018 PMR database.

69. The low-level indicator on Licences and Permits includes information on the licensing regime for new firms and the efforts made to ensure that the system is lean and fast. The results show that there is scope to reduce the red tape for start-ups in several countries Figure 20). Indeed the licensing process can still be complex both in OECD and in non-OECD countries; in particular, many countries still make extensive use of licences and permits, and do not have a single physical office or online website where entrepreneurs can find information on all licences and permits they may need and can obtain them. 
Figure 20. Low-level indicator on Licences and Permits in 2018

Countries ranked in ascending order from most (0) to least (6) competition friendly

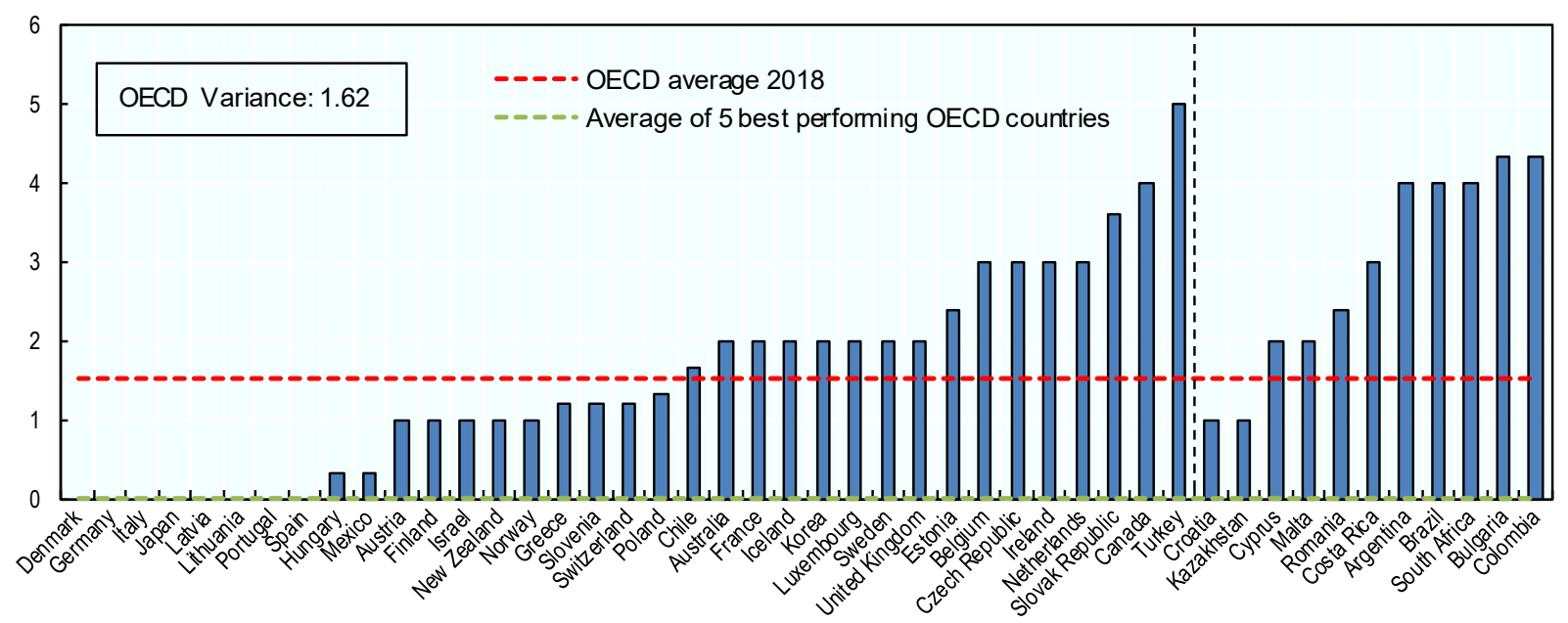

Note: A vertical dotted line divides the countries in two groups: before the line the OECD countries and after the non-OECD ones. The horizontal red dotted line represents the OECD average and the green one the average of the five countries with the most competition-friendly regulatory environment. If a bar does not appear on the chart, it means that its value is 0 . The US is the only OECD country not included in the OECD averages, because the PMR data collection was not complete at the time of publication. Information refers to laws and regulations in force on 1 January 2018 and for a few countries 1 January 2019. Source: OECD 2018 PMR database.

70. The indicators on Barriers in Service Sectors and Barriers in Network Sectors capture the barriers to entry and expansion that firms face in the service sectors (retail trade, professional services and taxis) and in the network sectors (energy, e-communications, transport, and water). Overall, there are more regulatory obstacles to competition in service sectors than in network sectors, both in OECD and nonOECD countries (Figure 21 and Figure 22). In addition, OECD countries tend to be have more similar regulatory set-ups in network sectors, than in service sectors, as shown by the difference in the variances. 
Figure 21. Low-level Indicator on Barriers in Service Sectors in 2018

Countries ranked in ascending order from most (0) to least (6) competition friendly

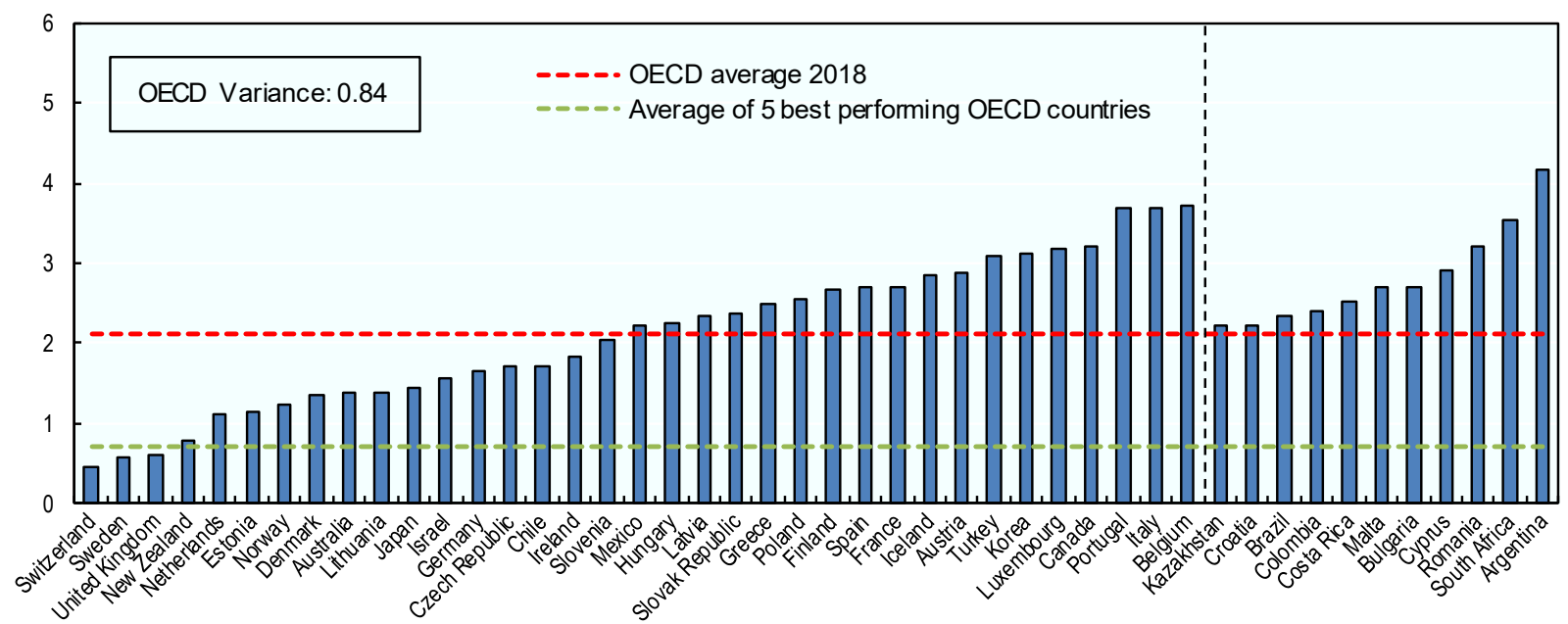

Note: A vertical dotted line divides the countries in two groups: before the line the OECD countries and after the non-OECD ones. The horizontal red dotted line represents the OECD average and the green one the average of the five countries with the most competition-friendly regulatory environment. If a bar does not appear on the chart, it means that its value is 0 . The US is the only OECD country not included in the OECD averages, because the PMR data collection was not complete at the time of publication. Information refers to laws and regulations in force on 1 January 2018 and for a few countries 1 January 2019.

Source: OECD 2018 PMR database.

Figure 22. Low-level Indicator on Barriers in Network Sectors in 2018

Countries ranked in ascending order from most (0) to least (6) competition friendly

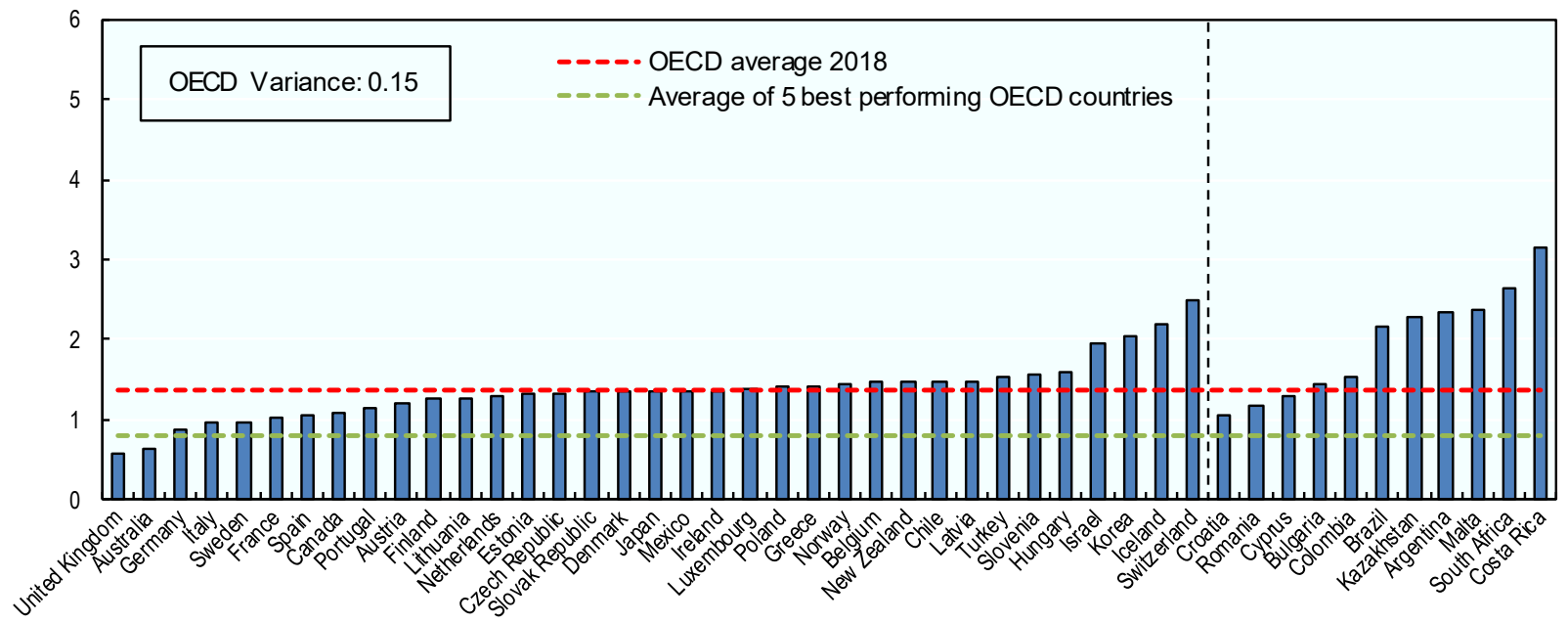

Note: A vertical dotted line divides the countries in two groups: before the line the OECD countries and after the non-OECD ones. The horizontal red dotted line represents the $O E C D$ average and the green one the average of the five countries with the most competition-friendly regulatory environment. If a bar does not appear on the chart, it means that its value is 0 . The US is the only OECD country not included in the OECD averages, because the PMR data collection was not complete at the time of publication. Information refers to laws and regulations in force on 1 January 2018 and for a few countries 1 January 2019.

Source: OECD 2018 PMR database.

71. Even tough in most OECD countries barriers to trade and investment are generally quite low; the barriers faced by foreign firms or foreign professionals trying to enter other national markets tend to be higher (Figure 23) Mexico and Israel stand out among OECD countries with a score that is even higher 
than non-OECD countries surveyed (including those with a relatively high score such as Argentina, Colombia, Kazakhstan, and South Africa).

\section{Figure 23. Low-level Indicator on Treatment of Foreign Suppliers in 2018}

Countries ranked in ascending order from most (0) to least (6) competition friendly

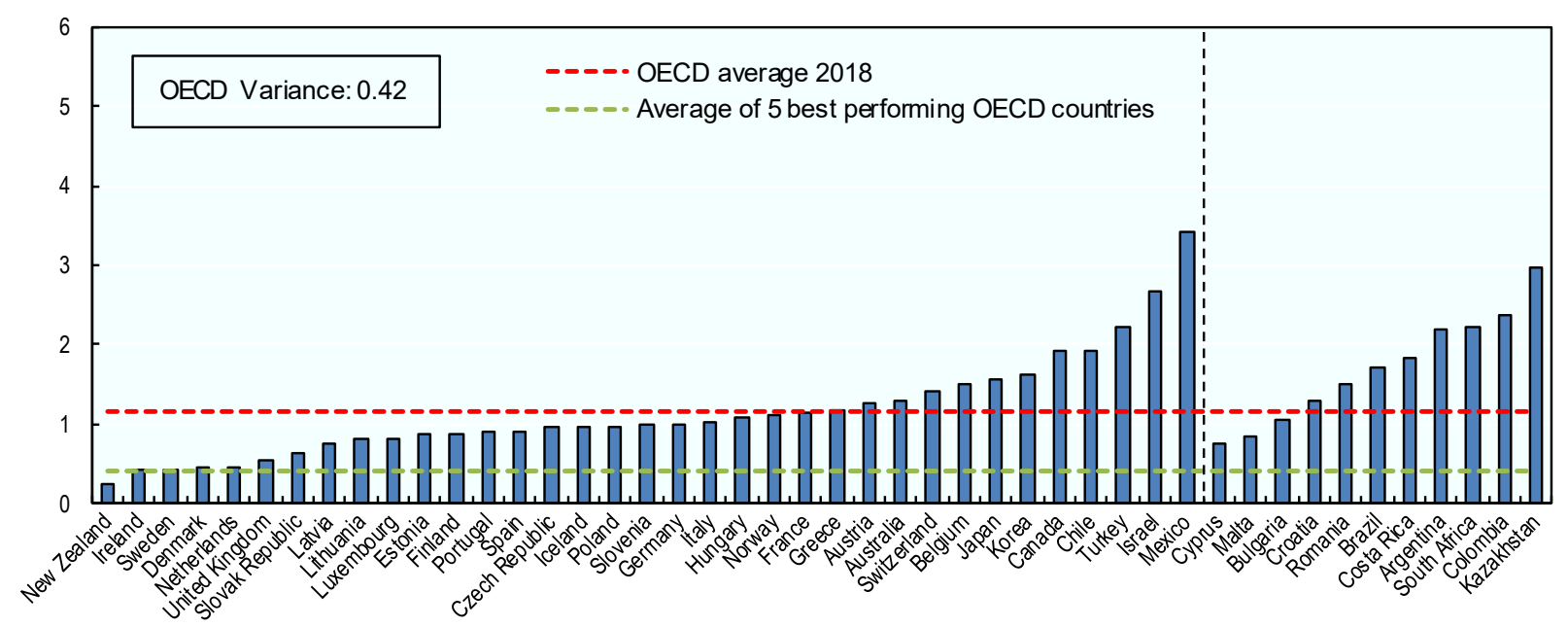

Note: A vertical dotted line divides the countries in two groups: before the line the OECD countries and after the non-OECD ones. The horizontal red dotted line represents the OECD average and the green one the average of the five countries with the most competition-friendly regulatory environment. If a bar does not appear on the chart, it means that its value is 0 . The US is the only OECD country not included in the OECD averages, because the PMR data collection was not complete at the time of publication. Information refers to laws and regulations in force on 1 January 2018 and for a few countries 1 January 2019.

Source: OECD 2018 PMR database.

\section{Product market regulation in 2018: the regulatory stance at the sector level}

72. A set of sector-based indicators complement the economy-wide PMR indicator. They measure the incidence of regulatory barriers to competition at the level of specific network and service sectors. This section reports the 2018 results for these indicators.

\subsection{Network Sectors}

\section{Fixed and Mobile E-communication}

73. Among network industries, e-communications is the one where OECD countries appear, for the most part, to be closest to best practice (Figure 24). Indeed the OECD average is very low and the average for the five best-performing OECD countries is close to zero. However, a few OECD and several nonOECD countries present higher values.

74. Values across the fixed and mobile segments are very similar for most countries. 


\section{Figure 24. PMR sector indicators for the E-communication fixed and mobile sectors*}

Countries ranked in ascending order from most (0) to least (6) competition friendly

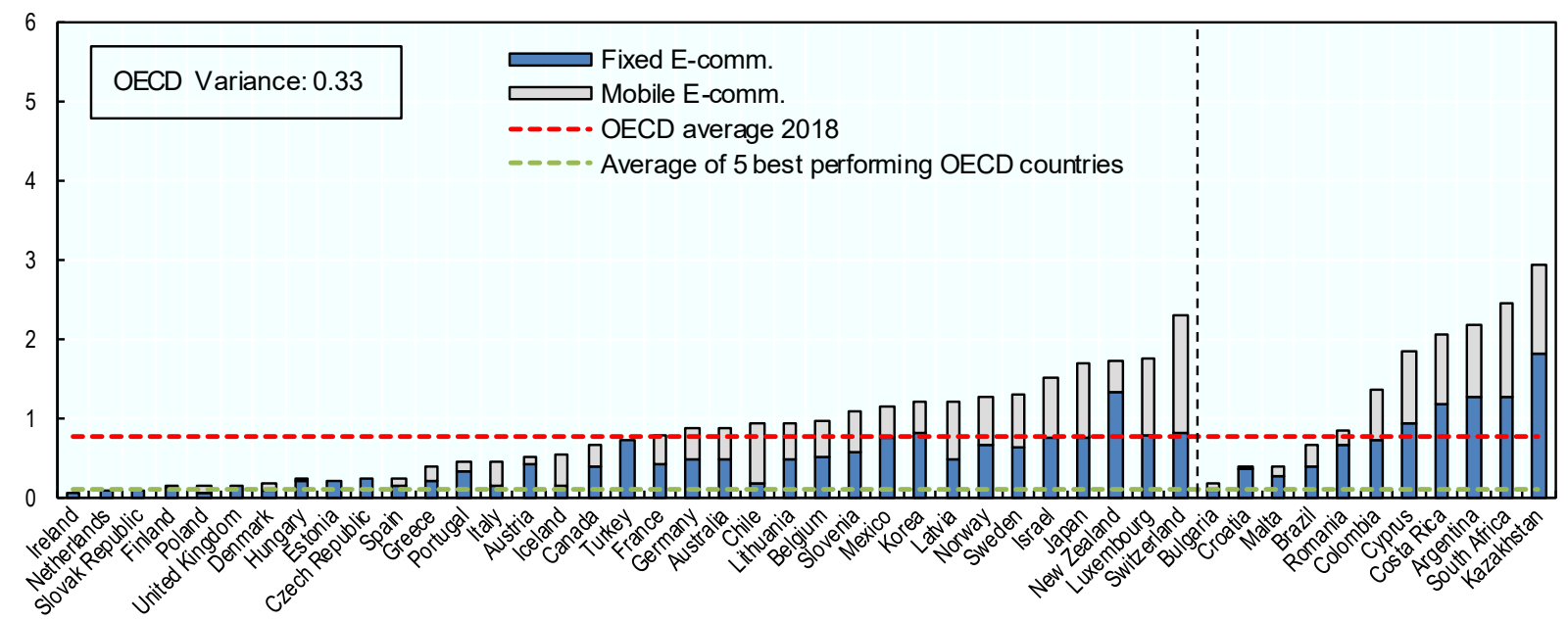

Note*: This indicator is an average of the two indicators for mobile and fixed e-communications and its value is here broken down into this two components. To obtain the original values of the indicators for the sub-sectors one would have to multiply the value in the figures by 2 .

Note: A vertical dotted line divides the countries in two groups: before the line the OECD countries and after the non-OECD ones. The horizontal red dotted line represents the OECD average and the green one the average of the five countries with the most competition-friendly regulatory environment. If a bar does not appear on the chart, it means that its value is 0 . The US is the only OECD country not included in the OECD averages, because the PMR data collection was not complete at the time of publication. Information refers to laws and regulations in force on 1 January 2018 and for a few countries 1 January 2019.

Source: OECD 2018 PMR database.

75. The sector indicators for network industries include information on the level of public ownership and control of firms as well as on the nature of regulation on entry and conduct in each of these industries. Figure 25Figure 25 and Figure 26show the breakdown of the sector indicators for fixed and mobile ecommunications in these two components.

76. This breakdown helps to better understand what drives the results. For example, countries that are members of the European Union tend to have very low values when only regulation is considered. This is because the EU regulatory requirements in this area are highly competition friendly. However, when one considers the level of public ownership, the values for some of these countries increase, since some of the largest operators are still partially owned by the state. On the other hand, Korea and Israel, where there is almost no public ownership in these sectors, have high scores because several aspects of their regulation creates barriers to competition. 
Figure 25. Public ownership and regulation in the Fixed E-communications sector* Countries ranked in ascending order from most (0) to least (6) competition friendly

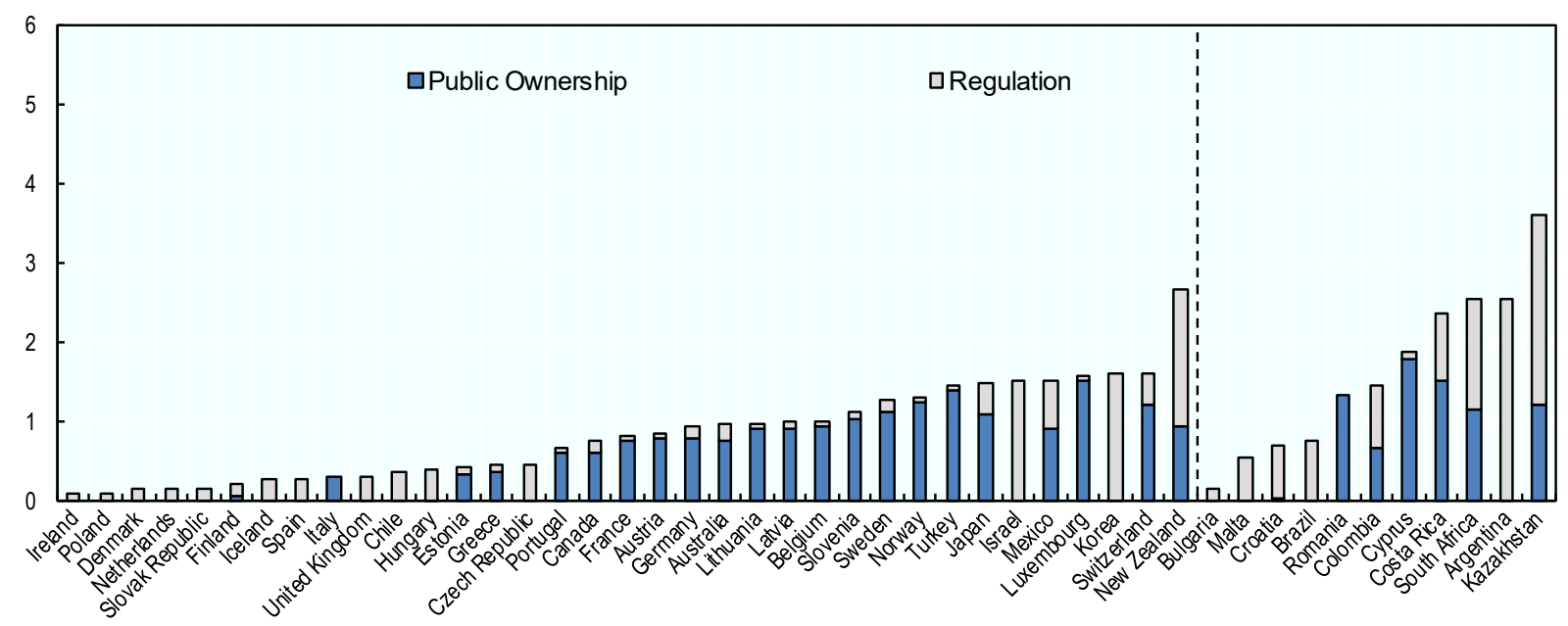

Note*: The two components - public ownership and regulation - are not sub-indicators. They only present a breakdown of the content of the indicators. Since there are many more data on regulation than on state involvement, calculating two sub-indicators would be distortive. This means that the overall value of that sector indicator is obtained by simply summing the values of these two components.

Note: A vertical dotted line divides the countries in two groups: before the line the OECD countries and after the non-OECD ones. If a bar does not appear on the chart, it means that its value is 0 . The US is the only OECD country not included in the OECD averages, because the PMR data collection was not complete at the time of publication. Information refers to laws and regulations in force on 1 January 2018 and for a few countries 1 January 2019.

Source: OECD 2018 PMR database.

Figure 26. Public ownership and regulation in the Mobile E-communications sector*

Countries ranked in ascending order from most (0) to least (6) competition friendly

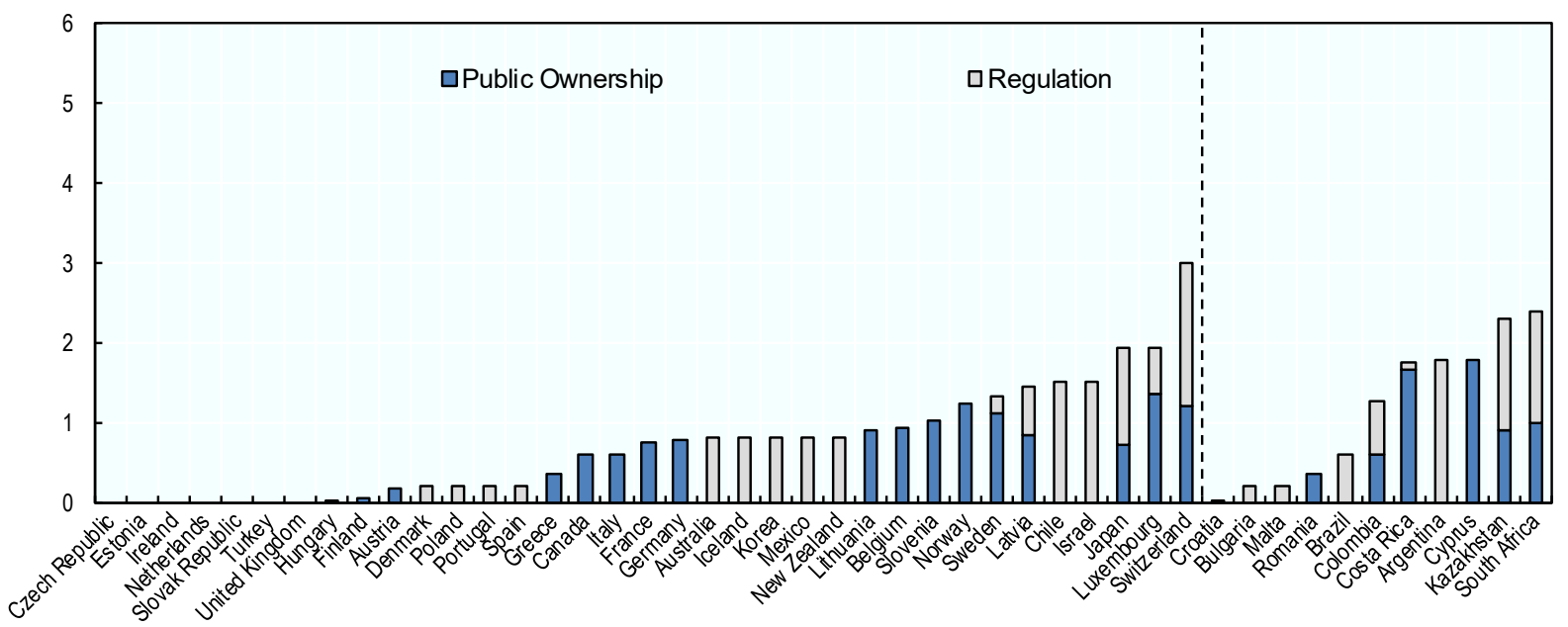

Note: The two components - public ownership and regulation - are not sub-indicators. They only present a breakdown of the content of the indicators. Since there are many more data on regulation than on state involvement, calculating two sub-indicators would be distortive. This means that the overall value of that sector indicator is obtained by simply summing the values of these two components.

Note: A vertical dotted line divides the countries in two groups: before the line the OECD countries and after the non-OECD ones. If a bar does not appear on the chart, it means that its value is 0 . The US is the only OECD country not included in the OECD averages, because the PMR data collection was not complete at the time of publication. Information refers to laws and regulations in force on 1 January 2018 and for a few countries 1 January 2019.

Source: OECD 2018 PMR database. 


\section{Energy}

77. The indicator for the energy industry provides information on both the electricity and natural gas sectors (Figure 27). The values for this industry are on average higher and there is more variation, than in the case of e-communications. Nevertheless, the values are still quite low for most OECD countries and only Korea and Switzerland stand out as having very high values (i.e. 2.5 or above ). On the contrary, half of the non-OECD countries have values above 2.5. This implies that in latter group of countries there is clearly scope for improvements in this area.

\section{Figure 27. PMR sector indicators for the Energy Sector*}

Countries ranked in ascending order from most (0) to least (6) competition friendly

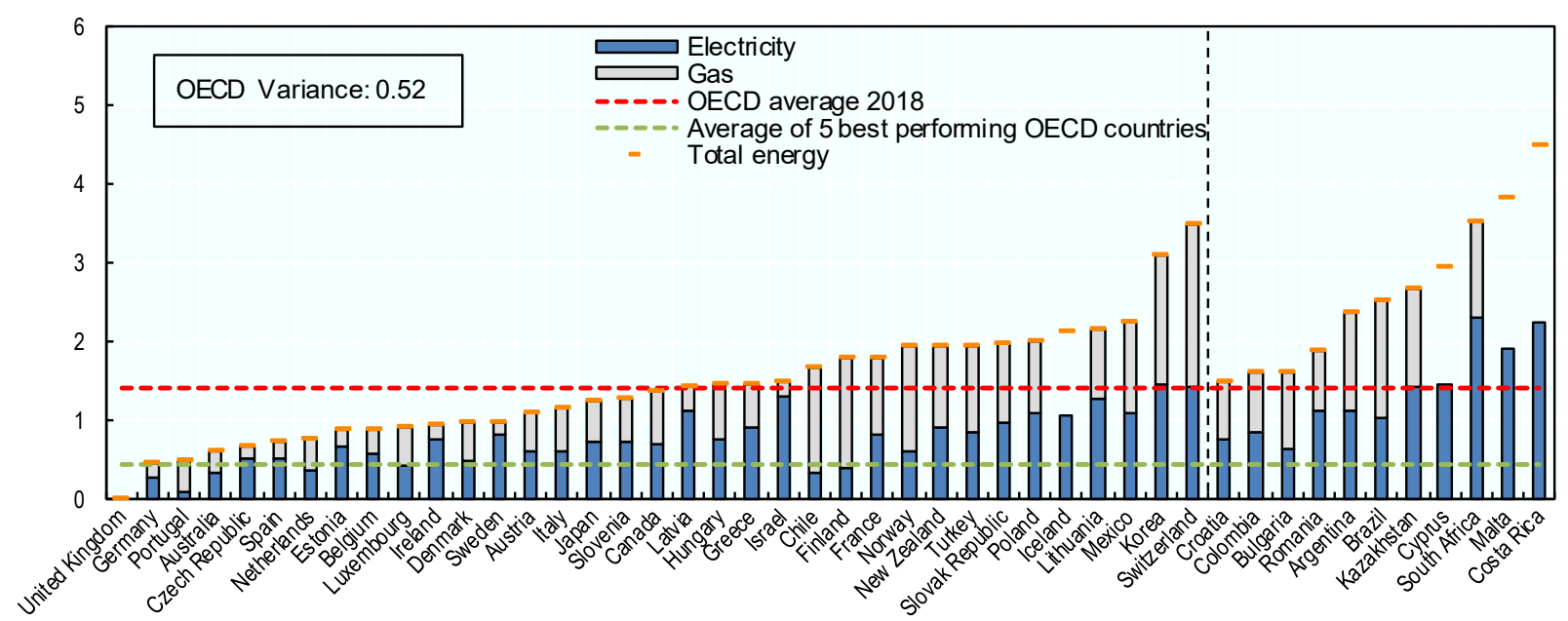

Note: In Iceland, Costa Rica, Cyprus and Malta, the natural gas sector is non-existent, hence only the electricity sector is considered in the indicator. This explains the difference between the total value and the value for the only sector that exists.

Note: A vertical dotted line divides the countries in two groups: before the line the OECD countries and after the non-OECD ones. The horizontal red dotted line represents the $O E C D$ average and the green one the average of the five countries with the most competition-friendly regulatory environment. If a bar does not appear on the chart, it means that its value is 0 . The US is the only OECD country not included in the OECD averages, because the PMR data collection was not complete at the time of publication. Information refers to laws and regulations in force on 1 January 2018 and for a few countries 1 January 2019. Source: OECD 2018 PMR database. 
78. Figure 28 and 29 show the breakdown of the sector indicators for the two energy segments into their main components: public ownership and regulation.

\section{Figure 28. Public ownership and regulation in the Electricity sector*}

Countries ranked in ascending order from most (0) to least (6) competition friendly

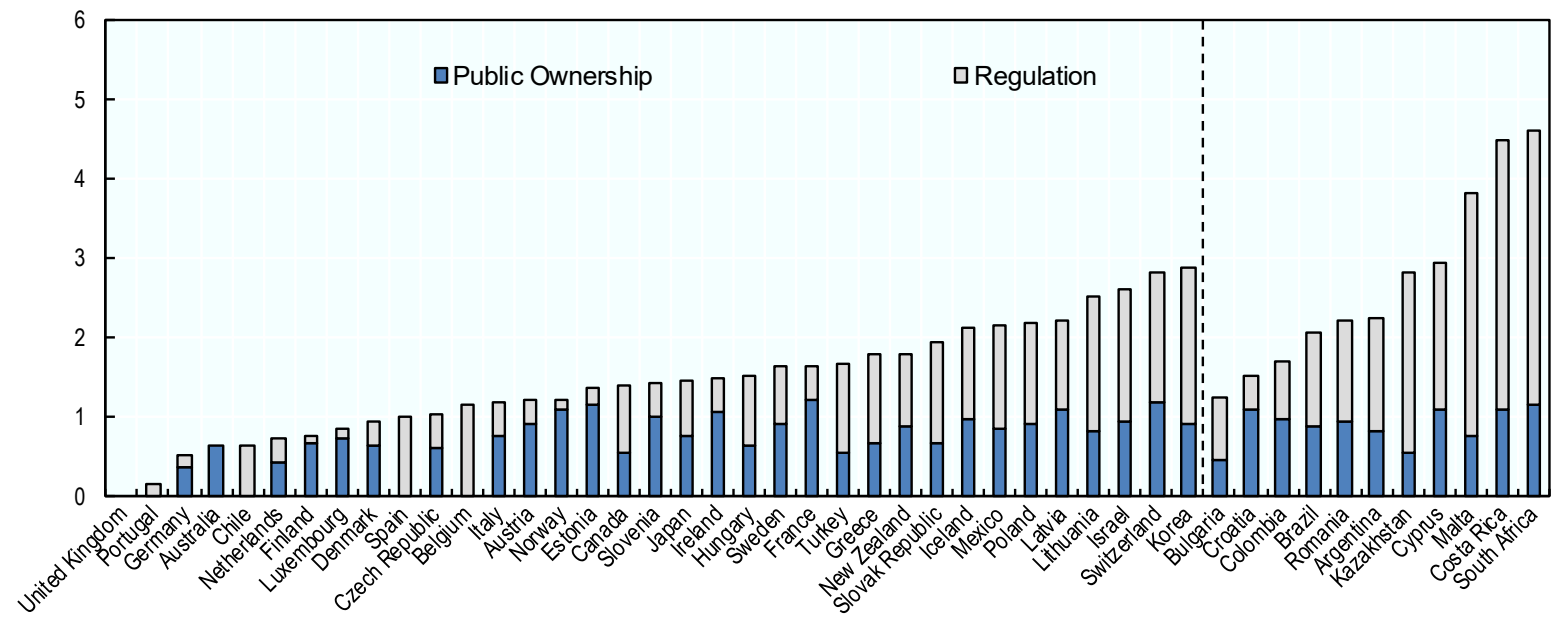

Note*: The two components - public ownership and regulation - are not sub-indicators. They only present a breakdown of the content of the indicators. Since there are many more data on regulation than on state involvement, calculating two sub-indicators would be distortive. This means that the overall value of that sector indicator is obtained by simply summing the values of these two components.

Note: A vertical dotted line divides the countries in two groups: before the line the OECD countries and after the non-OECD ones. If a bar does not appear on the chart, it means that its value is 0 . Information refers to laws and regulations in force on 1 January 2018 and for a few countries 1 January 2019.

Source: OECD 2018 PMR database.

\section{Figure 29. Public ownership and regulation in the Natural Gas sector*}

Countries ranked in ascending order from most (0) to least (6) competition friendly

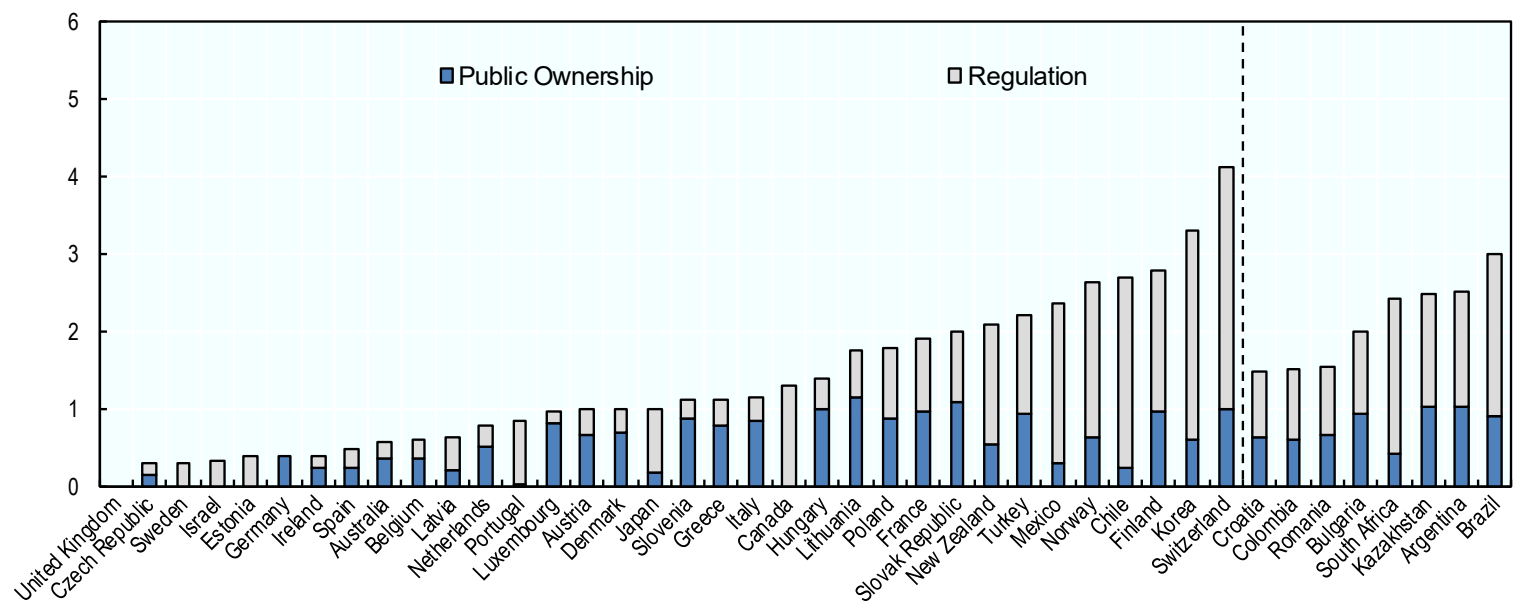

Note*: The two components - public ownership and regulation - are not sub-indicators. They only present a breakdown of the content of the indicators. Since there are many more data on regulation than on state involvement, calculating two sub-indicators would be distortive. This means that the overall value of that sector indicator is obtained by simply summing the values of these two components. In Iceland, Costa Rica, Cyprus and Malta, the natural gas sector does not exist; hence, these 4 countries do not appear in this figure.

Note: A vertical dotted line divides the countries in two groups: before the line the OECD countries and after the non-OECD ones. If a bar does not appear on the chart, it means that its value is 0 . Information refers to laws and regulations in force on 1 January 2018 and for a few countries 1 January 2019.

Source: OECD 2018 PMR database. 


\section{The transport industry}

79. The regulatory stance for the overall transport industry tends to be rather similar across OECD countries, both at an aggregate level and at the level of individual transport sectors (as shown by the OECD variances in Table 1). Instead, there is more variation when it comes to the non-OECD countries surveyed (see variance in Table 1).

80. The clearest trend that can be identified in these results is that the values are mostly driven by transport by rail, which is the sector that tends to be more stringently regulated and where public ownership is often still high (more than in other transport sectors or in other network industries) (Figure 30). Indeed, in many OECD and non-OECD countries in the market for passenger transport by rail there is neither competition in the market (i.e. the market has not been opened up to competition), nor competition for the market (i.e. there is still limited use of tenders to allocate public sector contracts). In addition, vertical integration between the rail infrastructure provider and one or more rail operators is still widespread and independently owned infrastructure manager/system operator are not yet very common.

\section{Figure 30. PMR sector indicators for the Transport sector*}

Countries ranked in ascending order from most (0) to least (6) competition friendly

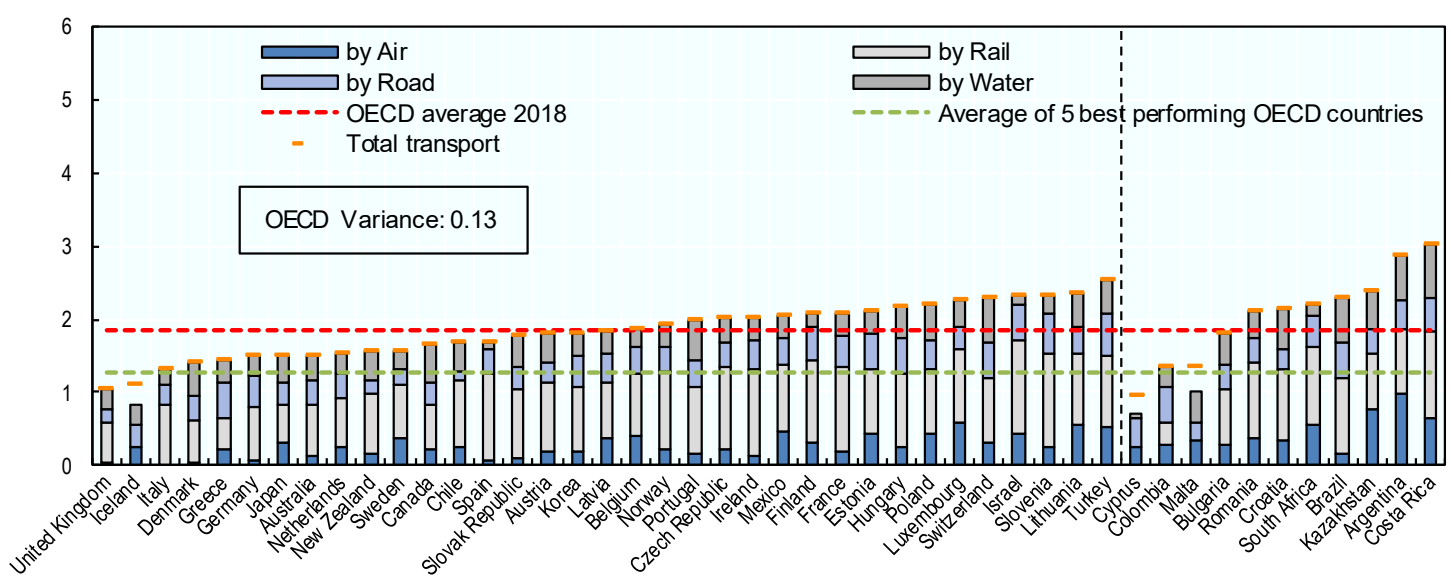

Note*: In Iceland, Cyprus and Malta, the rail transport sector does not exist. This explains the difference between the total value and the values for the 3 sectors that exist.

Note: A vertical dotted line divides the countries in two groups: before the line the OECD countries and after the non-OECD ones. The horizontal red dotted line represents the OECD average and the green one the average of the five countries with the most competition-friendly regulatory environment. If a bar does not appear on the chart, it means that its value is 0 . The US is the only OECD country not included in the OECD averages, because the PMR data collection was not complete at the time of publication. Information refers to laws and regulations in force on 1 January 2018 and for a few countries 1 January 2019.

Source: OECD 2018 PMR database.

Table 1. Average values for the four transport sectors

\begin{tabular}{l|r|r|r|r}
\hline & \multicolumn{4}{|c}{ Transport } \\
\hline & By Air & \multicolumn{1}{|c}{ By Rail } & \multicolumn{1}{c}{ By Road } & \multicolumn{1}{c}{ By Water } \\
\hline OECD average & 1.05 & 3.57 & 1.44 & 1.37 \\
\hline Average of 5 OECD best performing countries & 0.17 & 2.14 & 0.76 & 0.70 \\
\hline OECD Variance & 0.37 & 0.73 & 0.17 & 0.20 \\
\hline Variance for non-OECD countries surveyed & 0.94 & 0.97 & 0.10 & 0.64 \\
\hline Variance for all the countries surveyed & 0.61 & 0.78 & 0.15 & 0.33 \\
\hline
\end{tabular}

Note: The US is the only OECD country not included in the OECD averages and variances, because the PMR data collection was not complete at the time of publication. Information refers to laws and regulations in force on 1 January 2018 and for a few countries 1 January 2019. Source: OECD 2018 PMR database. 


\subsection{Service Sectors}

\section{Professional services}

81. The indicators for professional services assess the nature of the regulation on both entry and on conduct for six professional figures: accountants, lawyers, notaries, architects, civil engineers, and real estate agents.

82. While in the past the PMR questionnaire collected information by groups of professions, the 2018 PMR one focuses on individual professions. This change has been made to increase the comparability across countries of the data collected and of the resulting indicators. Despite this effort, some care should be taken when comparing the PMR indicators on individual professions because the nature and number of activities that are reserved to a specific profession may vary between countries. Hence, in some cases, the difference in values may be due to differences in regulation, which is what these indicators aim to capture, while in other cases, this difference may be driven by differences in the activities undertaken ${ }^{17}$.

83. For example, in some countries accountants are mostly responsible for preparing financial accounts for firms, handling payrolls, reconciling firms' books at end of the financial year, and filling in tax returns, while a separate professional figure, the auditor, performs statutory auditing activities. In other countries, however, accountants also perform statutory auditing activities. Since these statutory auditing activities are essential to ensuring the efficient operation of financial markets, the professionals who undertake are often subject to stricter entry and conduct regulation. This difference in the activities undertaken by accountants may lead to higher values for the latter group of countries. However, differences across countries in the same group are clearly due to difference in the way entry and conduct are regulated.

84. The values of these six indicators are often quite high, both for OECD and non-OECD countries, but with considerable variance across countries. It is often claimed that these high scores are justified because access to these professions, as well as the conduct of professionals and professional firms, should constrained to address market failures resulting from the asymmetry of information between consumers and providers. The argument is that professional services are "experience goods" (i.e. a product or a service whose quality, and hence price, is difficult to evaluate in advance), and in some cases even credence goods (difficulty to assess quality even after the service has been purchased). Consumers of these types of goods need to be protected from the risk of encountering low quality providers and of incurring financial or personal damages.

85. However, the variance shown by these values suggests that this argument may not be valid and that in many countries there is scope of an assessment of the regulation imposed on professionals to ensure that the market failures effectively exist. Such an assessment would permit policymakers to determine if all the existing regulatory constraints are necessary and whether they strike the right balance between fostering competition and innovation and protecting consumers.

17 The PMR database provides a detailed indication of the activities performed by each profession in each country, and it should always be referred to when examining and comparing these indicators. 
Table 2. Average values for the six professions

\begin{tabular}{l|r|r|r|r|r|r}
\hline & Accountants & Architects & Civil engineers & Real estate agents & Lawyers & Notaries \\
\hline OECD average & 1.10 & 1.50 & 1.28 & 0.82 & 3.19 & 4.66 \\
\hline Average of 5 OECD best performing countries & 0.00 & 0.04 & 0.00 & 0.00 & 1.35 & 3.03 \\
\hline Average for all the countries surveyed & 1.26 & 1.63 & 1.37 & 0.91 & 3.25 & 4.72 \\
\hline OECD variance & 1.70 & 1.06 & 1.11 & 0.69 & 0.93 & 1.19 \\
\hline Variance for all the countries surveyed & 1.71 & 0.98 & 0.93 & 0.89 & 0.95 & 1.05 \\
\hline
\end{tabular}

Note: The US is the only OECD country not included in the OECD averages and variances, because the PMR data collection was not complete at the time of publication. Information refers to laws and regulations in force on 1 January 2018 and for a few countries 1 January 2019. Source: OECD 2018 PMR database.

\section{Accountants}

86. As mentioned above, accountants are professionals who are mostly responsible for preparing financial accounts for firms, handling payrolls, reconcile firms' books at end of the financial year, and filling in tax returns for firms and individuals.

87. In about one third of the OECD and non-OECD countries surveyed, accountants are not a regulated profession (value 0 in Figure 31). In half of the remaining countries, accountants also perform statutory auditing activities (rather than auditors being a separate profession), which could justify why in these countries the profession is regulated.

88. Nevertheless, if one considers separately the countries where accountants and auditors are a single profession (marked in yellow in Figure 31 and those where they are two separate ones (marked in blue in Figure 31), the level of the barriers to entry and conduct imposed on these professionals varies significantly across these two groups. This suggests that there is scope for reassessing regulation for this profession, as the height of the regulatory barriers does not seem to be correlated with the need to ensure the quality and reliability of auditing activities.

\section{Figure 31. PMR sectoral indicators for Accountants}

Countries ranked in ascending order from most (0) to least (6) competition friendly

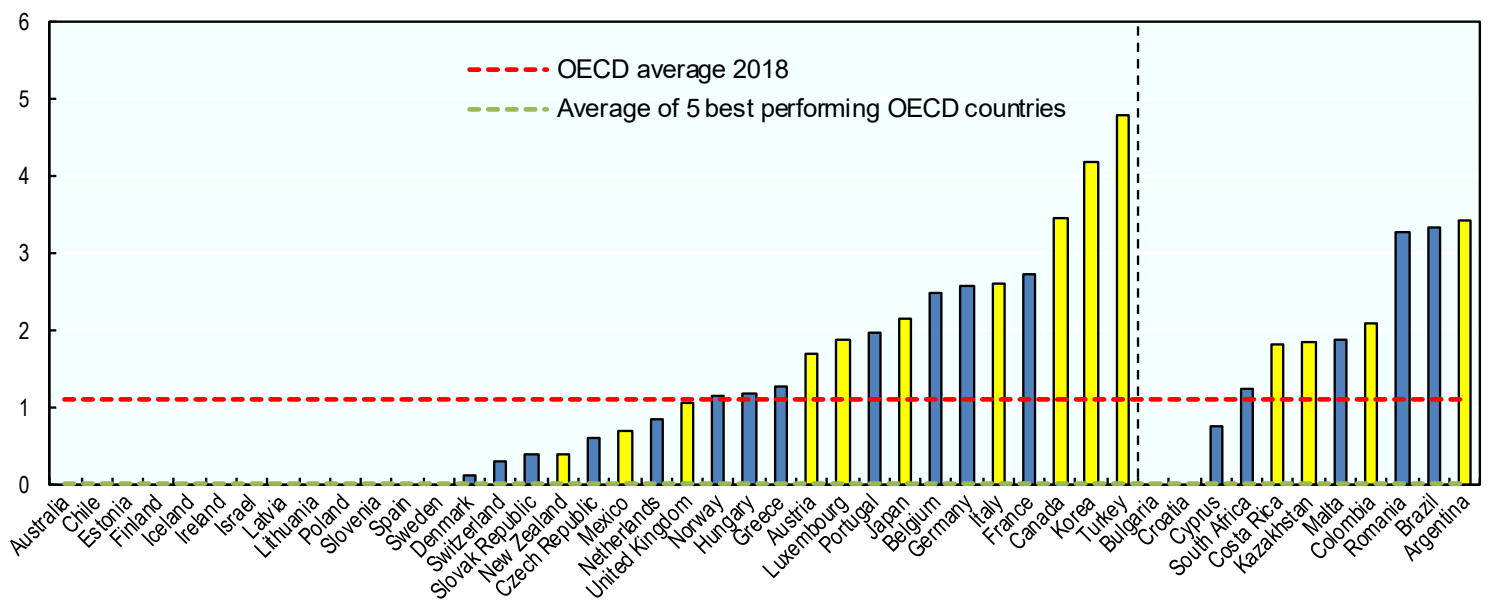

Note: A vertical dotted line divides the countries in two groups: before the line the OECD countries and after the non-OECD ones. The red line represents the $O E C D$ average and the green one the average of the five countries with the most competition-friendly regulatory environment. The countries marked in yellow are those where accountants and auditors are a single profession. If a bar does not appear on the chart, it means that its value is 0 . The US is the only OECD country not included in the OECD averages, because the PMR data collection was not complete at the time of publication. Information refers to laws and regulations in force on 1 January 2018 and for a few countries 1 January 2019.

Source: OECD 2018 PMR database. 


\section{Architects and Civil Engineers}

89. Architects and civil engineers are professionals whose main responsibilities are to design, plan and supervise the construction of buildings. Despite similarities in their reserved activities, it is interesting to note that about $50 \%$ of the countries surveyed apply different levels of regulation to these two professions. In addition, there is considerable variety in the way each of these two professions are regulated both among OECD and non-OECD countries (Figure 32 and Figure 33 ).

\section{Figure 32. PMR sector indicators for Architects}

Countries ranked in ascending order from most (0) to least (6) competition friendly

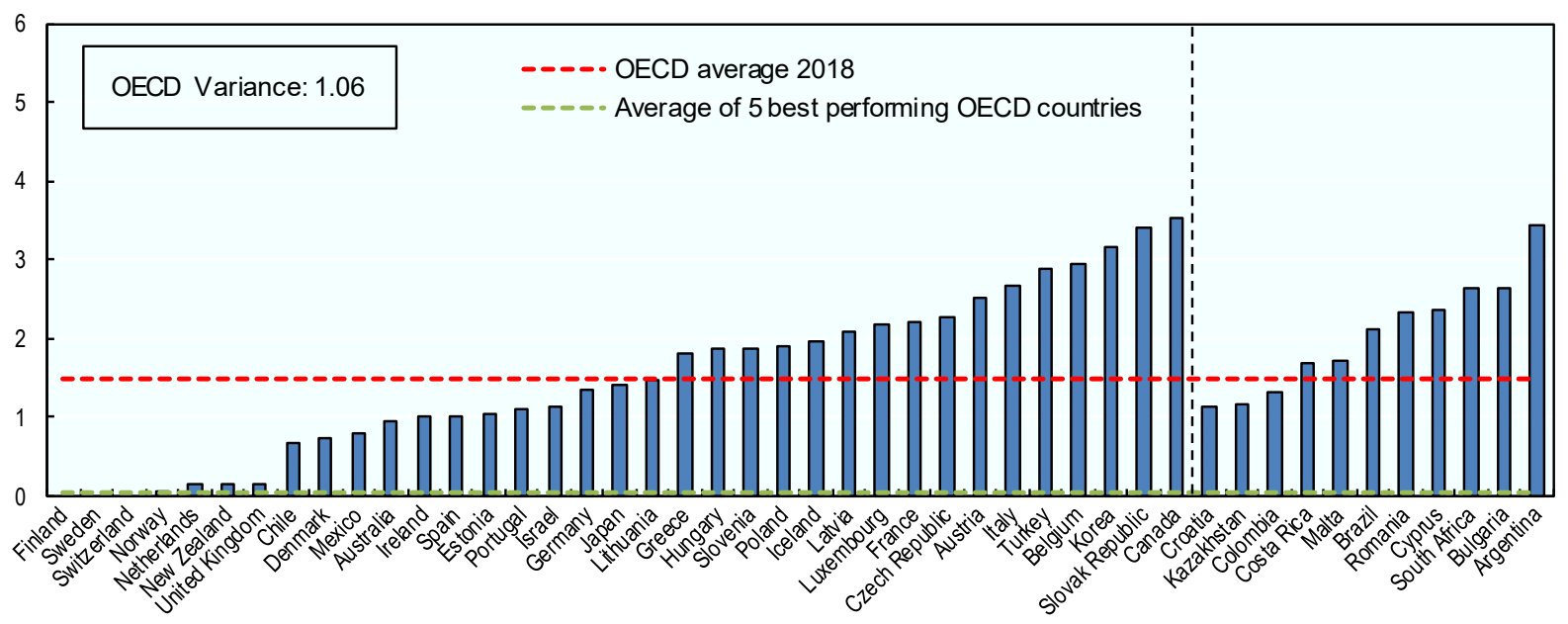

Note: A vertical dotted line divides the countries in two groups: before the line the OECD countries and after the non-OECD ones. The horizontal red dotted line represents the OECD average and the green one the average of the five countries with the most competition-friendly regulatory environment. If a bar does not appear on the chart, it means that its value is 0 . The US is the only OECD country not included in the OECD averages, because the PMR data collection was not complete at the time of publication. Information refers to laws and regulations in force on 1 January 2018 and for a few countries 1 January 2019.

Source: OECD 2018 PMR database. 


\section{Figure 33. PMR sector indicators for Civil Engineers}

Countries ranked in ascending order from most (0) to least (6) competition friendly

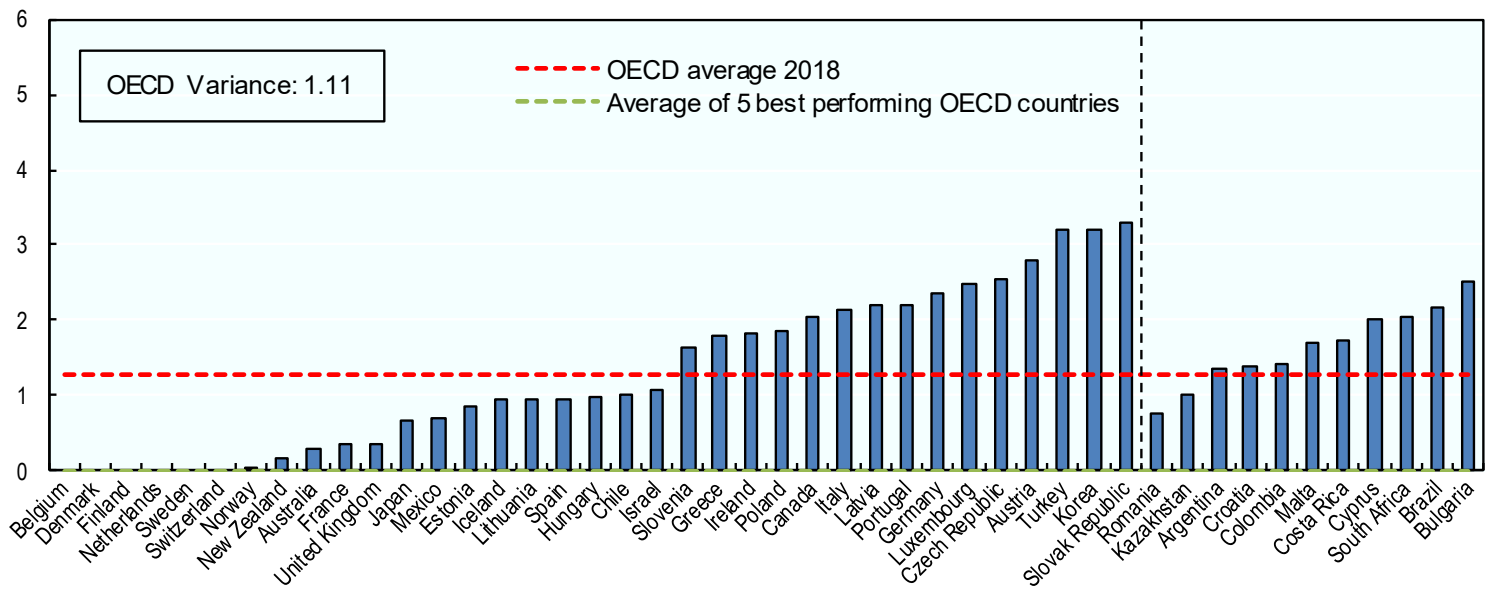

Note: A vertical dotted line divides the countries in two groups: before the line the OECD countries and after the non-OECD ones. The horizontal red dotted line represents the OECD average and the green one the average of the five countries with the most competition-friendly regulatory environment. If a bar does not appear on the chart, it means that its value is 0 . The US is the only OECD country not included in the OECD averages, because the PMR data collection was not complete at the time of publication. Information refers to laws and regulations in force on 1 January 2018 and for a few countries 1 January 2019.

Source: OECD 2018 PMR database.

\section{Real estate Agents}

90. Real estate agents are professionals whose main responsibilities consist in arranging the selling, letting and/or management of real estate properties. The level of regulation of this profession is, on average, quite low $^{18}$ (Figure 34), but there are some exceptions. In some countries, regulation is stricter in because real estate agents share with lawyers and/or notaries the ability to perform conveyancing activities (marked in yellow in Figure 34). However, some other countries have a high score despite the fact that conveyancing is not among the activities reserved to this profession.

\footnotetext{
18 The sector indicator for real estate agents is equal to 0 for eleven countries (i.e. no regulation is imposed), and is above 0 but less than to 0.5 for eight other countries (i.e. regulation is very limited).
} 
Figure 34. PMR sector indicators for Real Estate Agents

Countries ranked in ascending order from most (0) to least (6) competition friendly

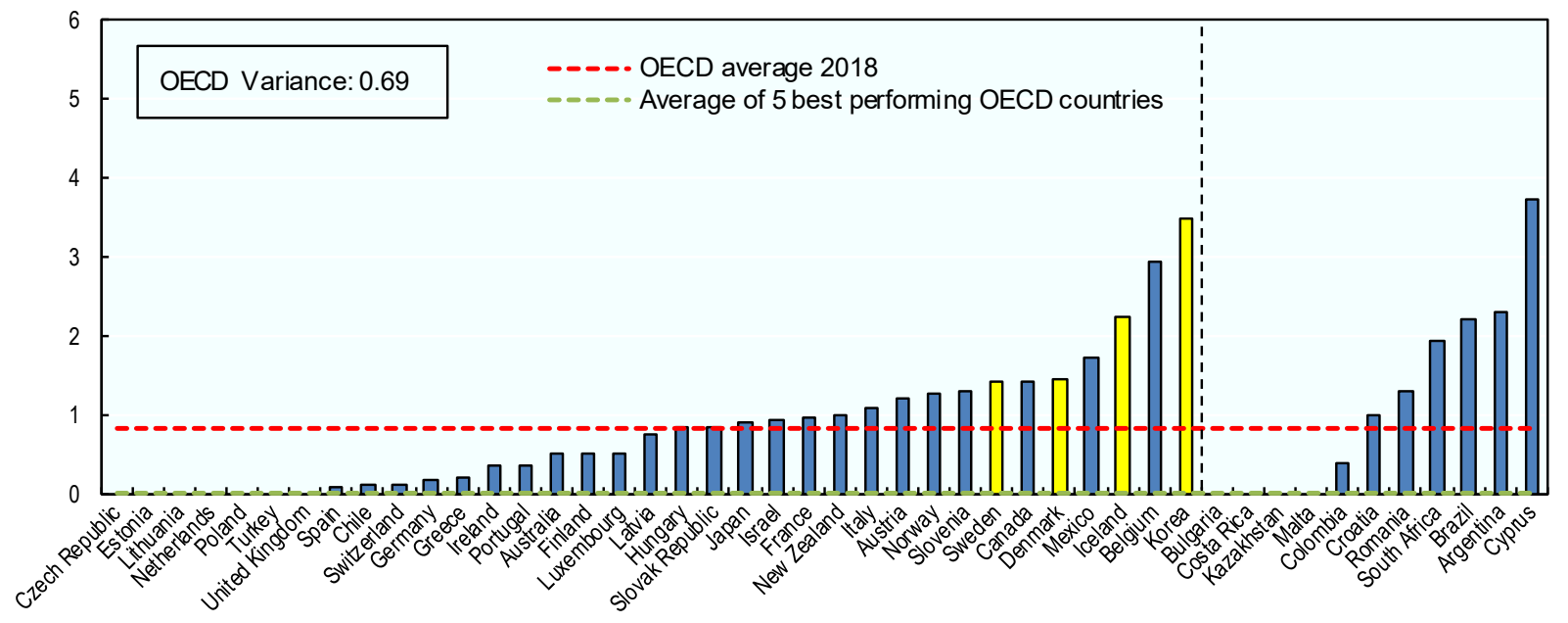

Note: A vertical dotted line divides the countries in two groups: before the line the OECD countries and after the non-OECD ones. The horizontal red dotted line represents the OECD average and the green one the average of the five countries with the most competition-friendly regulatory environment. The countries marked in yellow are those where real estate agents can also undertake conveyancing services. If a bar does not appear on the chart, it means that its value is 0 . The US is the only OECD country not included in the OECD averages, because the PMR data collection was not complete at the time of publication. Information refers to laws and regulations in force on 1 January 2018 and for a few countries 1 January 2019.

Source: OECD 2018 PMR database.

\section{Lawyers and Notaries}

91. In past vintages of the PMR indicators for professional services, there was a single indicator for the legal profession. In order to ensure greater comparability and capture the level of regulation of the two most relevant professions in this area, the 2018 version separated the indicators that measure the regulation of lawyers and notaries.

92. Even more than for the other professions, it is important to highlight that care needs to be taken when performing cross-country comparisons of these indicators, because differences in legal systems can have an impact on the nature and level of regulation of these two professions.

93. In the case of lawyers, the level of regulation is quite high in both OECD and non-OECD countries (Figure 35). However, there are a few countries, such as Chile, Mexico, Australia, and the United Kingdom, that impose considerably less constraints on the profession. 


\section{Figure 35. PMR sector indicators for Lawyers}

Countries ranked in ascending order from most (0) to least (6) competition friendly

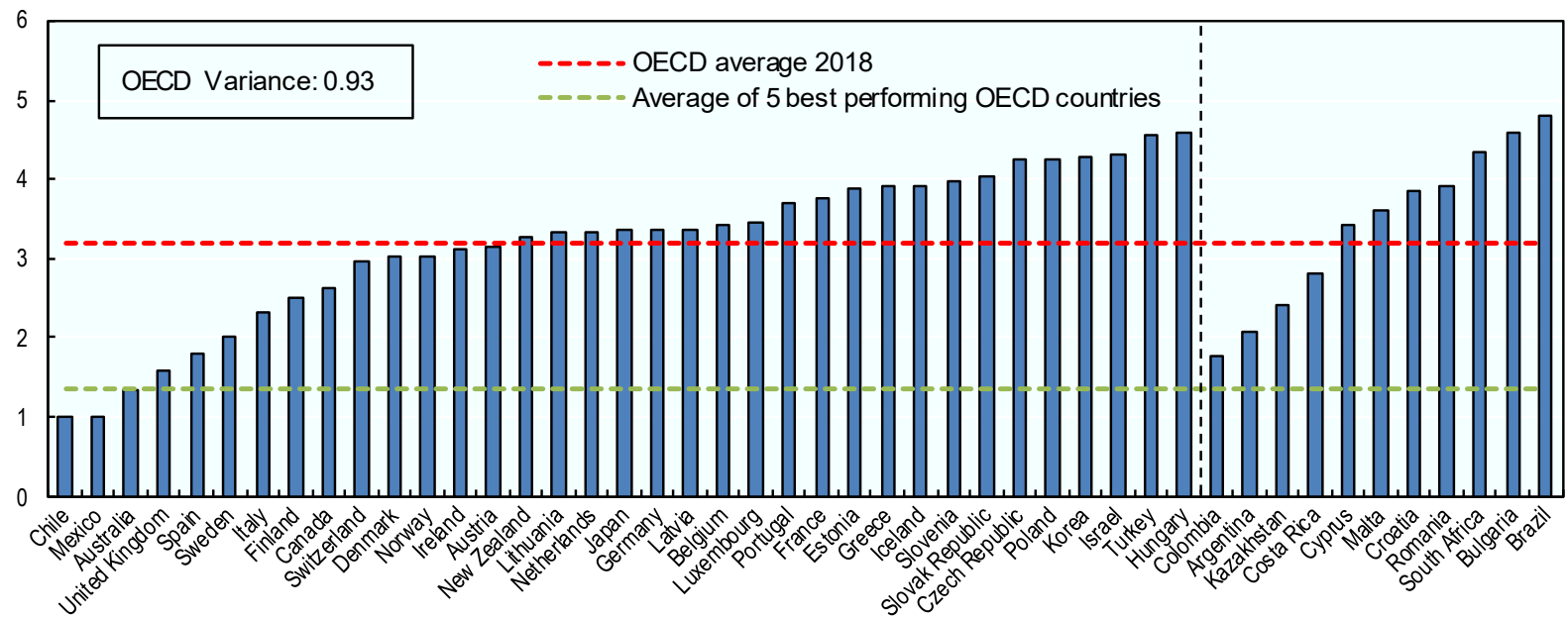

Note: A vertical dotted line divides the countries in two groups: before the line the OECD countries and after the non-OECD ones. The horizontal red dotted line represents the OECD average and the green one the average of the five countries with the most competition-friendly regulatory environment. If a bar does not appear on the chart, it means that its value is 0 . The US is the only OECD country not included in the OECD averages, because the PMR data collection was not complete at the time of publication. Information refers to laws and regulations in force on 1 January 2018 and for a few countries 1 January 2019.

Source: OECD 2018 PMR database.

94. The analysis of the regulation of notaries (Figure 36) deserves some additional qualifications. First, notaries do not exist as an independent profession in all the countries surveyed. For this reason there are values missing for this profession for some countries. Furthermore, in civil law countries, highly represented in our sample, notaries exercise administrative and judicial tasks by virtue of power delegated by the state. Hence, notaries play a special role in the legal services market in these countries that justifies some regulatory constraints.

95. The higher level of regulation that characterises notaries is, therefore, partly due to their special role as guarantors of the authenticity of legal documents and contracts. However, even when one considers this factor, there are still countries that have managed to reduce regulatory constraints. Indeed France and the Netherlands have both made an effort to reduce regulatory constraints to entry in this profession and have lower levels of regulation than other countries with similar legal set-ups. For example, in the Netherlands, there are no quantitative restrictions that limit entry in this profession and notaries agree their fees with their clients (i.e. neither public authorities nor the professional chamber regulate the fees). This suggests that there is room for reviewing the regulation that disciplines access to this profession and its conduct in many countries. 
Figure 36. PMR sector indicators for Notaries*

Countries ranked in ascending order from most (0) to least (6) competition friendly

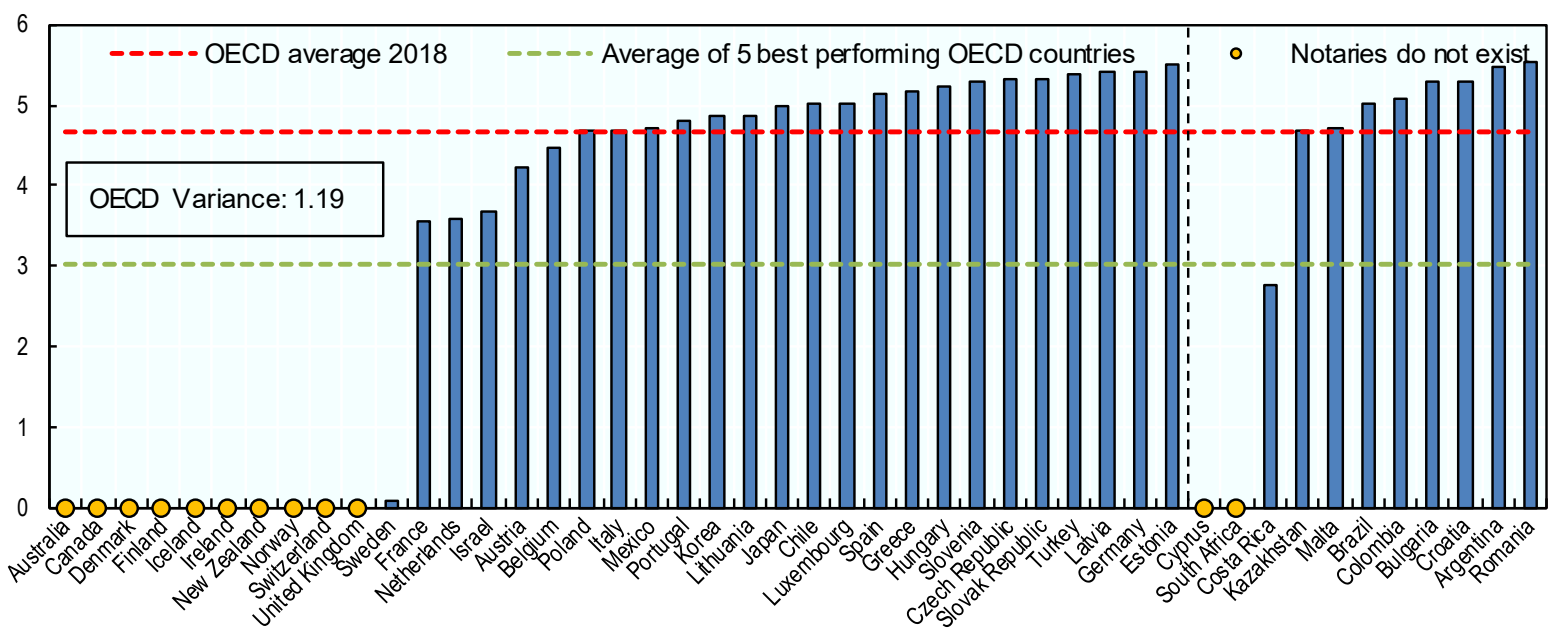

Note : In some countries, notaries do not exist as an independent profession. For this reason there are values missing for some countries Note: A vertical dotted line divides the countries in two groups: before the line the OECD countries and after the non-OECD ones. The horizontal red dotted line represents the OECD average and the green one the average of the five countries with the most competition-friendly regulatory environment. If a bar does not appear on the chart, it means that its value is 0 . The US is the only OECD country not included in the OECD averages, because the PMR data collection was not complete at the time of publication. Information refers to laws and regulations in force on 1 January 2018 and for a few countries 1 January 2019.

Source: OECD 2018 PMR database.

\section{The retail sector}

\section{General retail trade}

96. A few countries have significantly removed unnecessary barriers to competition in retail distribution, while for many there are still margins for improvement (Figure 37). In particular, quite a few OECD and non-OECD countries impose greater administrative obligations on online sellers than they do on retailers that use brick and mortar outlets ${ }^{19}$. Shop opening hours are also still heavily constrained in some countries. Another interesting aspect is that many of the countries with the highest scores, such as Italy, Portugal, Greece and Belgium, are OECD countries and EU member states. ${ }^{20}$ remember that the PMR does not cover other areas, such as taxes, where online sellers may instead have an advantage over brick and mortar competitors.
} 


\section{Figure 37. PMR sector indicators for Retail Trade}

Countries ranked in ascending order from most (0) to least (6) competition friendly

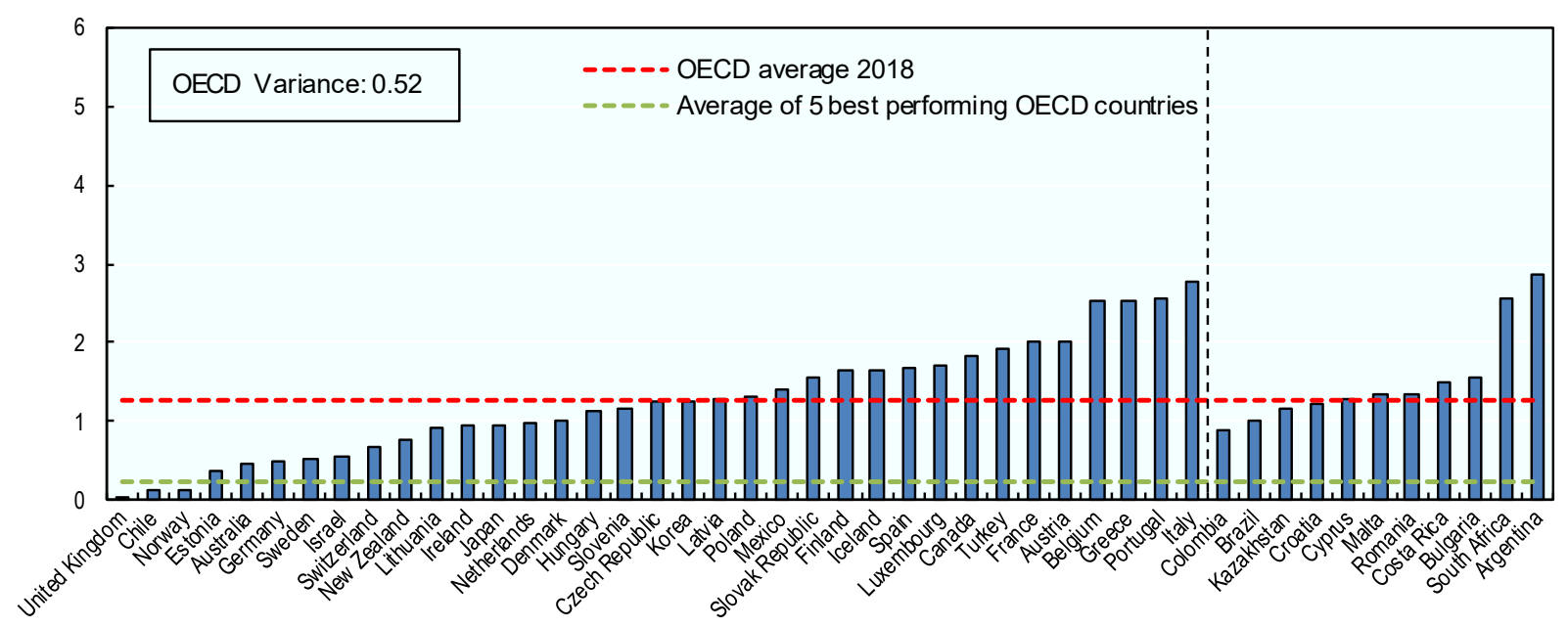

Note: A vertical dotted line divides the countries in two groups: before the line the OECD countries and after the non-OECD ones. The horizontal red dotted line represents the OECD average and the green one the average of the five countries with the most competition-friendly regulatory environment. If a bar does not appear on the chart, it means that its value is 0 . The US is the only OECD country not included in the OECD averages, because the PMR data collection was not complete at the time of publication. Information refers to laws and regulations in force on 1 January 2018 and for a few countries 1 January 2019.

Source: OECD 2018 PMR database.

\section{Retail sale of medicines}

97. The retail sale of medicines is regulated in very different ways across OECD and non-OECD countries (Figure 38). While all countries require some supervision over the sale of prescription medicines, some countries have considerably relaxed the constraints over the sale of non-prescription medicines (for example they can be sold in other retail outlets and in some cases even in supermarkets). In addition, the regulatory restrictions imposed on pharmacies, which usually have the monopoly over the sale of prescription medicines (and in some cases of all medicines) vary considerably across countries, with some imposing strongly limits on their number, location, ownership structure and opening hours, and other countries allowing pharmacies freedom in all these areas.

98. This one is the indicator with the largest variance across OECD countries (see Figure 2) at the beginning of the document). In addition, it is interesting to note that non-OECD countries generally regulate this sector less strictly than OECD ones.

99. Most of the constraints revolve around pharmacies: their number, location, ownership, opening hours and monopoly over the sale of specific products. This suggests that reconsidering the level of regulatory protection pharmacies benefit from may lead to welfare gains for consumers in many countries, especially within the OECD. 
Figure 38. PMR sector indicators for Retail Sale of Medicines

Countries ranked in ascending order from most (0) to least (6) competition friendly

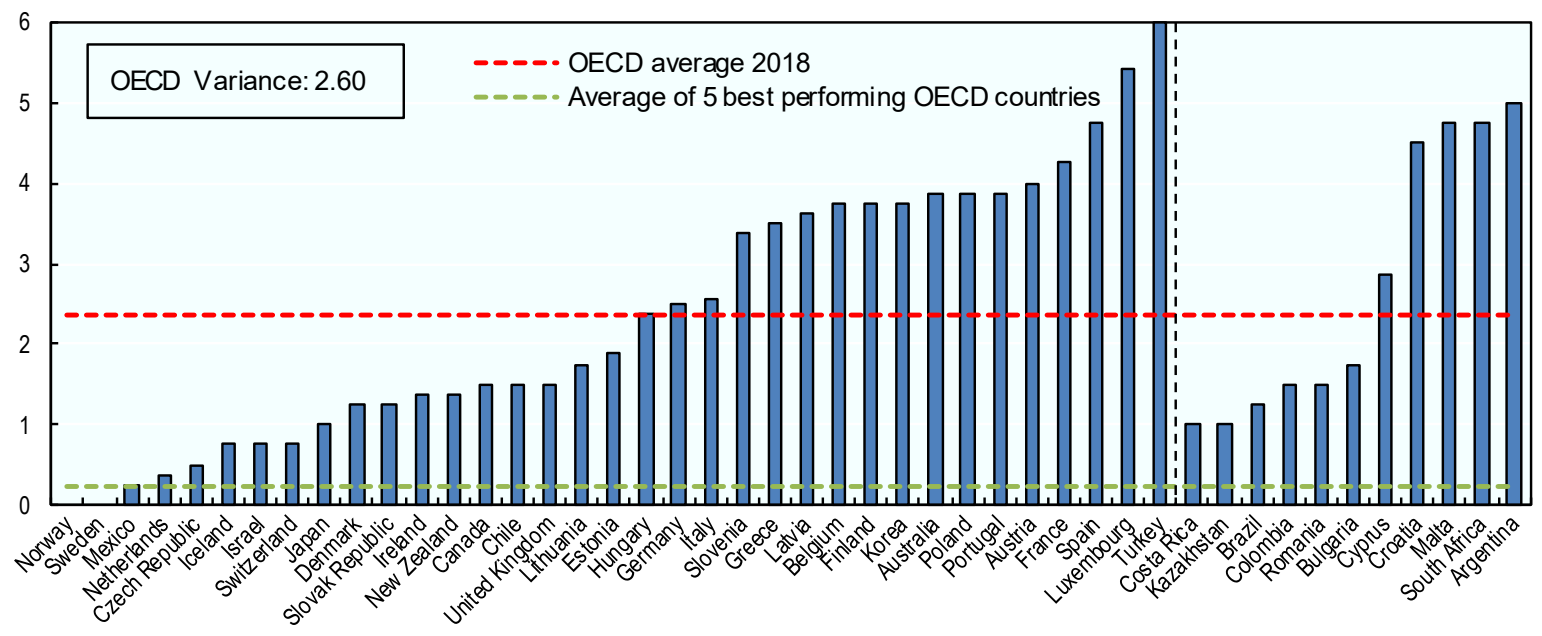

Note: A vertical dotted line divides the countries in two groups: before the line the OECD countries and after the non-OECD ones. The horizontal red dotted line represents the OECD average and the green one the average of the five countries with the most competition-friendly regulatory environment. If a bar does not appear on the chart, it means that its value is 0 . The US is the only OECD country not included in the OECD averages, because the PMR data collection was not complete at the time of publication. Information refers to laws and regulations in force on 1 January 2018 and for a few countries 1 January 2019.

Source: OECD 2018 PMR database. 


\section{Annex A. Values of all economy-wide PMR indicators}

100. This Annex includes the tables with the values of all the indicators included in the economy-wide PMR indicator.

101. Table A1 contains the values of:

- the overall economy-wide PMR indicator,

- $\quad$ its two high-level indicators (Distortions Induced by State Involvement and Barriers to Domestic and Foreign Entry), and

- $\quad$ its six medium-level ones (Public Ownership, Involvement in Business Operations, Simplification and Evaluation of Regulations, Administrative Burden on Start-ups, Barriers in Service and Network sectors, and Barriers to Trade and Investment). 


\section{$\mathbf{5 0} \mid \operatorname{ECO} / \mathrm{WKP}(2020) 12$}

Table A.1. Values of the overall economy-wide indicator, the two high-level indicators, and the six medium-level ones (OECD countries)

\begin{tabular}{|c|c|c|c|c|c|c|c|c|c|}
\hline & \multirow{2}{*}{$\begin{array}{c}\text { Overall } \\
\text { Indicator }\end{array}$} & \multicolumn{2}{|c|}{2 High level Indicators } & \multicolumn{6}{|c|}{6 Medium level Indicators } \\
\hline & & $\begin{array}{l}\text { Distortions } \\
\text { Induced by } \\
\text { State } \\
\text { Involvement }\end{array}$ & $\begin{array}{c}\text { Barriers to } \\
\text { Domestic } \\
\text { and Foreign } \\
\text { Entry }\end{array}$ & $\begin{array}{c}\text { Public } \\
\text { Ownership }\end{array}$ & $\begin{array}{l}\text { Involvement } \\
\text { in Business } \\
\text { Operations }\end{array}$ & $\begin{array}{l}\text { Simplification } \\
\text { and } \\
\text { Evaluation of } \\
\text { Regulations }\end{array}$ & $\begin{array}{l}\text { Admin. } \\
\text { Burden } \\
\text { on Start- } \\
\text { ups }\end{array}$ & $\begin{array}{l}\text { Barriers in } \\
\text { Service and } \\
\text { Network } \\
\text { Sectors }\end{array}$ & $\begin{array}{l}\text { Barriers to } \\
\text { Trade and } \\
\text { Investment }\end{array}$ \\
\hline \multicolumn{10}{|l|}{ OECD countries } \\
\hline Australia & 1.16 & 1.38 & 0.94 & 1.79 & 0.94 & 1.42 & 1.09 & 1.01 & 0.73 \\
\hline Austria & 1.44 & 1.65 & 1.23 & 1.79 & 1.02 & 2.14 & 0.94 & 2.04 & 0.71 \\
\hline Belgium & 1.69 & 1.67 & 1.71 & 1.75 & 1.38 & 1.89 & 1.88 & 2.60 & 0.64 \\
\hline Canada & 1.76 & 1.79 & 1.72 & 2.22 & 2.14 & 1.02 & 2.00 & 2.15 & 1.01 \\
\hline Chile & 1.41 & 1.55 & 1.27 & 1.30 & 1.13 & 2.22 & 1.02 & 1.59 & 1.20 \\
\hline Czech Republic & 1.30 & 1.33 & 1.26 & 1.71 & 0.95 & 1.34 & 1.72 & 1.51 & 0.56 \\
\hline Denmark & 1.02 & 1.42 & 0.63 & 1.69 & 0.90 & 1.66 & 0.16 & 1.34 & 0.39 \\
\hline Estonia & 1.29 & 1.50 & 1.07 & 2.18 & 0.87 & 1.46 & 1.51 & 1.23 & 0.47 \\
\hline Finland & 1.37 & 1.69 & 1.04 & 2.64 & 1.19 & 1.24 & 0.66 & 1.96 & 0.51 \\
\hline France & 1.57 & 1.83 & 1.32 & 2.98 & 1.56 & 0.96 & 1.56 & 1.85 & 0.54 \\
\hline Germany & 1.08 & 1.41 & 0.76 & 2.15 & 0.87 & 1.20 & 0.56 & 1.26 & 0.44 \\
\hline Greece & 1.56 & 1.99 & 1.12 & 1.73 & 1.51 & 2.74 & 0.73 & 1.95 & 0.68 \\
\hline Hungary & 1.32 & 1.58 & 1.05 & 2.07 & 0.71 & 1.95 & 0.60 & 1.92 & 0.64 \\
\hline Iceland & 1.44 & 1.22 & 1.67 & 1.40 & 0.56 & 1.69 & 1.75 & 2.52 & 0.73 \\
\hline Ireland & 1.38 & 1.54 & 1.23 & 2.37 & 0.55 & 1.70 & 1.75 & 1.60 & 0.34 \\
\hline Israel & 1.41 & 1.54 & 1.29 & 1.96 & 1.63 & 1.02 & 0.81 & 1.75 & 1.31 \\
\hline Italy & 1.32 & 1.57 & 1.07 & 2.04 & 1.02 & 1.64 & 0.27 & 2.33 & 0.59 \\
\hline Japan & 1.44 & 1.98 & 0.90 & 1.91 & 2.03 & 2.01 & 0.59 & 1.39 & 0.72 \\
\hline Korea & 1.71 & 1.69 & 1.72 & 2.21 & 1.92 & 0.93 & 1.09 & 2.59 & 1.49 \\
\hline Latvia & 1.28 & 1.81 & 0.75 & 2.40 & 1.24 & 1.80 & 0.00 & 1.91 & 0.34 \\
\hline Lithuania & 1.19 & 1.81 & 0.57 & 3.37 & 1.02 & 1.02 & 0.06 & 1.33 & 0.30 \\
\hline Luxembourg & 1.68 & 2.00 & 1.35 & 2.97 & 1.25 & 1.79 & 1.38 & 2.29 & 0.40 \\
\hline Mexico & 1.61 & 1.75 & 1.47 & 2.19 & 1.69 & 1.37 & 0.67 & 1.77 & 1.96 \\
\hline Netherlands & 1.10 & 1.13 & 1.07 & 1.49 & 0.54 & 1.34 & 1.75 & 1.20 & 0.26 \\
\hline New Zealand & 1.24 & 1.71 & 0.77 & 2.61 & 0.73 & 1.78 & 0.50 & 1.13 & 0.67 \\
\hline Norway & 1.15 & 1.41 & 0.90 & 2.75 & 0.73 & 0.73 & 0.72 & 1.34 & 0.63 \\
\hline Poland & 1.45 & 1.66 & 1.24 & 2.98 & 1.23 & 0.77 & 1.20 & 1.97 & 0.55 \\
\hline Portugal & 1.34 & 1.64 & 1.05 & 1.53 & 1.28 & 2.10 & 0.31 & 2.42 & 0.43 \\
\hline Slovak Republic & 1.52 & 1.54 & 1.50 & 2.19 & 0.96 & 1.48 & 2.17 & 1.85 & 0.48 \\
\hline Slovenia & 1.29 & 1.57 & 1.01 & 1.95 & 1.17 & 1.59 & 0.79 & 1.80 & 0.44 \\
\hline Spain & 1.03 & 1.21 & 0.85 & 1.29 & 1.42 & 0.93 & 0.19 & 1.88 & 0.48 \\
\hline Sweden & 1.11 & 1.46 & 0.77 & 2.35 & 0.71 & 1.31 & 1.13 & 0.76 & 0.43 \\
\hline Switzerland & 1.53 & 1.96 & 1.10 & 3.23 & 1.19 & 1.47 & 0.98 & 1.48 & 0.84 \\
\hline Turkey & 2.28 & 2.20 & 2.36 & 2.84 & 1.83 & 1.94 & 3.75 & 2.32 & 1.00 \\
\hline United Kingdom & 0.78 & 0.84 & 0.72 & 1.16 & 0.50 & 0.86 & 1.19 & 0.58 & 0.39 \\
\hline OECD average & 1.38 & 1.60 & 1.16 & 2.15 & 1.15 & 1.50 & 1.07 & 1.73 & 0.67 \\
\hline $\begin{array}{l}\text { Average } 5 \text { OECD } \\
\text { best performing } \\
\text { countries }\end{array}$ & 1.00 & 1.15 & 0.68 & 1.33 & 0.57 & 0.85 & 0.14 & 0.94 & 0.32 \\
\hline OECD variance & 0.07 & 0.07 & 0.14 & 0.32 & 0.18 & 0.21 & 0.54 & 0.25 & 0.13 \\
\hline
\end{tabular}


Table A.1. continued (non-OECD countries)

\begin{tabular}{|c|c|c|c|c|c|c|c|c|c|}
\hline & \multirow{2}{*}{$\begin{array}{c}\begin{array}{c}\text { Overall } \\
\text { Indicator }\end{array} \\
\text { PMR } \\
2018\end{array}$} & \multicolumn{2}{|c|}{2 High level Indicators } & \multicolumn{6}{|c|}{6 Medium level Indicators } \\
\hline & & $\begin{array}{l}\text { Distortions } \\
\text { Induced by } \\
\text { State } \\
\text { Involvement }\end{array}$ & $\begin{array}{c}\text { Barriers } \\
\text { to } \\
\text { Domestic } \\
\text { and } \\
\text { Foreign } \\
\text { Entry }\end{array}$ & $\begin{array}{c}\text { Public } \\
\text { Ownership }\end{array}$ & $\begin{array}{l}\text { Involvement } \\
\text { in Business } \\
\text { Operations }\end{array}$ & $\begin{array}{l}\text { Simplification } \\
\text { and } \\
\text { Evaluation of } \\
\text { Regulations }\end{array}$ & $\begin{array}{l}\text { Admin. } \\
\text { Burden } \\
\text { on } \\
\text { Start- } \\
\text { ups }\end{array}$ & $\begin{array}{l}\text { Barriers in } \\
\text { Service and } \\
\text { Network } \\
\text { Sectors }\end{array}$ & $\begin{array}{l}\text { Barriers to Trade } \\
\text { and Investment }\end{array}$ \\
\hline \multicolumn{10}{|l|}{$\begin{array}{l}\text { Non OECD } \\
\text { countries }\end{array}$} \\
\hline Argentina & 2.65 & 2.71 & 2.59 & 3.20 & 2.34 & 2.58 & 2.75 & 3.26 & 1.75 \\
\hline Brazil & 2.58 & 2.79 & 2.37 & 2.36 & 2.18 & 3.84 & 2.88 & 2.25 & 1.98 \\
\hline Bulgaria & 1.93 & 1.86 & 2.00 & 2.41 & 1.66 & 1.51 & 3.42 & 2.08 & 0.51 \\
\hline Colombia & 2.04 & 2.18 & 1.90 & 1.90 & 1.23 & 3.43 & 2.75 & 1.96 & 0.98 \\
\hline Costa Rica & 2.32 & 2.54 & 2.10 & 3.10 & 1.81 & 2.70 & 2.56 & 2.84 & 0.89 \\
\hline Croatia & 1.43 & 1.82 & 1.05 & 2.80 & 0.85 & 1.80 & 1.00 & 1.64 & 0.51 \\
\hline Cyprus & 1.80 & 1.92 & 1.68 & 2.05 & 1.75 & 1.97 & 2.50 & 2.10 & 0.44 \\
\hline Kazakhstan & 2.12 & 2.76 & 1.48 & 4.01 & 1.50 & 2.77 & 0.56 & 2.25 & 1.64 \\
\hline Malta & 1.54 & 1.71 & 1.37 & 1.87 & 1.03 & 2.21 & 1.22 & 2.53 & 0.36 \\
\hline Romania & 1.86 & 2.13 & 1.59 & 3.02 & 1.24 & 2.15 & 2.04 & 2.20 & 0.52 \\
\hline $\begin{array}{l}\text { South } \\
\text { Africa }\end{array}$ & 2.53 & 2.86 & 2.19 & 3.39 & 1.49 & 3.72 & 2.25 & 3.08 & 1.22 \\
\hline
\end{tabular}

Note: The US is the only OECD country not included in the OECD average and variance, because the PMR data collection was not complete at the time of publication. Information refers to laws and regulations in force on 1 January 2018 and for a few countries 1 January 2019.

Source: OECD 2018 PMR database.

102. Table A2 contains the values of the 10 low-level indicators included in the high-level indicator Distortions Induced by State Involvement and Table A3 contains the values of the eight low-level indicators included in the high-level indicator Barriers to Domestic and Foreign Entry. 
Table A.2. Values of the low-level indicators included in Distortions induced by State Involvement

\begin{tabular}{|c|c|c|c|c|c|c|c|c|c|c|}
\hline & \multicolumn{10}{|c|}{ Distortions Induced by State Involvement } \\
\hline & $\begin{array}{l}\text { Scope } \\
\text { of } \\
\text { SOEs }\end{array}$ & $\begin{array}{c}\text { Government } \\
\text { Involvement in } \\
\text { Network Sectors }\end{array}$ & $\begin{array}{l}\text { Direct } \\
\text { Control }\end{array}$ & $\begin{array}{l}\text { Governance } \\
\text { of SOEs }\end{array}$ & $\begin{array}{l}\text { Price } \\
\text { controls }\end{array}$ & $\begin{array}{l}\text { Command } \\
\& \text { control } \\
\text { regulation }\end{array}$ & $\begin{array}{c}\text { Public } \\
\text { procurement }\end{array}$ & $\begin{array}{l}\text { Assessment of } \\
\text { Impact on } \\
\text { Competition }\end{array}$ & $\begin{array}{l}\text { Interaction } \\
\text { with } \\
\text { Interest } \\
\text { Groups }\end{array}$ & $\begin{array}{l}\text { Complexity } \\
\text { of } \\
\text { Regulatory } \\
\text { Procedures }\end{array}$ \\
\hline \multicolumn{11}{|l|}{ OECD countries } \\
\hline Australia & 2.44 & 0.75 & 1.71 & 2.25 & 0.67 & 1.41 & 0.75 & 0.75 & 2.32 & 1.20 \\
\hline Austria & 2.96 & 2.84 & 0.70 & 0.67 & 0.09 & 1.83 & 1.13 & 0.75 & 3.68 & 2.00 \\
\hline Canada & 3.04 & 1.00 & 0.94 & 3.90 & 1.37 & 1.31 & 3.75 & 0.75 & 1.64 & 0.67 \\
\hline Chile & 1.13 & 0.79 & 1.17 & 2.10 & 1.12 & 0.55 & 1.71 & 1.88 & 2.18 & 2.60 \\
\hline Czech Republic & 2.07 & 1.86 & 0.50 & 2.40 & 0.90 & 0.83 & 1.13 & 0.75 & 3.27 & 0.00 \\
\hline Denmark & 2.46 & 1.89 & 0.31 & 2.10 & 0.53 & 0.68 & 1.50 & 1.63 & 2.86 & 0.50 \\
\hline Estonia & 2.90 & 2.73 & 1.46 & 1.65 & 0.48 & 1.37 & 0.75 & 0.75 & 3.14 & 0.50 \\
\hline Finland & 3.98 & 3.31 & 1.94 & 1.35 & 1.00 & 1.08 & 1.50 & 0.75 & 2.32 & 0.67 \\
\hline Hungary & 3.46 & 1.81 & 1.07 & 1.95 & 0.84 & 1.30 & 0.00 & 1.50 & 3.95 & 0.40 \\
\hline Iceland & 1.44 & 1.63 & 0.74 & 1.80 & 0.08 & 0.48 & 1.13 & 0.75 & 3.41 & 0.90 \\
\hline Ireland & 2.83 & 2.62 & 1.65 & 2.40 & 0.25 & 0.84 & 0.56 & 1.50 & 1.09 & 2.50 \\
\hline Israel & 2.25 & 2.67 & 0.98 & 1.95 & 1.37 & 0.96 & 2.57 & 1.50 & 0.55 & 1.00 \\
\hline Italy & 3.12 & 1.54 & 1.35 & 2.17 & 0.23 & 1.34 & 1.50 & 0.75 & 3.68 & 0.48 \\
\hline Japan & 2.83 & 1.35 & 0.74 & 2.70 & 1.44 & 1.28 & 3.38 & 0.75 & 3.27 & 2.00 \\
\hline Korea & 2.58 & 2.21 & 1.35 & 2.70 & 2.85 & 1.96 & 0.94 & 0.75 & 2.05 & 0.00 \\
\hline Latvia & 3.38 & 3.43 & 0.85 & 1.95 & 1.06 & 1.15 & 1.50 & 3.75 & 1.64 & 0.00 \\
\hline Lithuania & 4.41 & 4.15 & 1.93 & 3.00 & 1.46 & 1.23 & 0.38 & 0.75 & 1.42 & 0.90 \\
\hline Luxembourg & 4.21 & 3.99 & 1.29 & 2.40 & 0.29 & 1.95 & 1.50 & 0.75 & 4.23 & 0.40 \\
\hline Mexico & 2.79 & 1.66 & 0.69 & 3.60 & 1.90 & 1.10 & 2.06 & 1.50 & 1.91 & 0.70 \\
\hline Spain & 1.42 & 1.19 & 0.89 & 1.65 & 1.02 & 1.56 & 1.69 & 0.75 & 2.05 & 0.00 \\
\hline Sweden & 3.58 & 3.16 & 1.51 & 1.17 & 0.00 & 0.41 & 1.71 & 0.75 & 2.18 & 1.00 \\
\hline Switzerland & 4.42 & 4.26 & 2.29 & 1.95 & 1.34 & 1.10 & 1.13 & 0.75 & 3.27 & 0.40 \\
\hline Turkey & 3.35 & 3.31 & 2.61 & 2.10 & 2.89 & 1.84 & 0.75 & 1.13 & 3.68 & 1.00 \\
\hline United Kingdom & 1.61 & 0.00 & 0.78 & 2.25 & 0.25 & 0.89 & 0.38 & 0.00 & 1.58 & 1.00 \\
\hline OECD average & 3.02 & 2.26 & 1.21 & 2.10 & 0.99 & 1.19 & 1.28 & 1.08 & 2.53 & 0.89 \\
\hline $\begin{array}{l}\text { Average of } 5 \\
\text { OECD best } \\
\text { performing } \\
\text { countries }\end{array}$ & 1.51 & 0.75 & 0.39 & 0.97 & 0.13 & 0.48 & 0.41 & 0.50 & 0.98 & 0.00 \\
\hline OECD variance & 1.01 & 1.08 & 0.33 & 0.49 & 0.48 & 0.20 & 0.58 & 0.45 & 1.01 & 0.50 \\
\hline
\end{tabular}


Table A.2. continued (non-OECD countries)

\begin{tabular}{|c|c|c|c|c|c|c|c|c|c|c|}
\hline & \multicolumn{10}{|c|}{ Distortions Induced by State Involvement } \\
\hline & $\begin{array}{l}\text { Scope } \\
\text { of } \\
\text { SOEs }\end{array}$ & $\begin{array}{l}\text { Government } \\
\text { Involvement in } \\
\text { Network } \\
\text { Sectors }\end{array}$ & $\begin{array}{l}\text { Direct } \\
\text { Control }\end{array}$ & $\begin{array}{l}\text { Governance } \\
\text { of SOEs }\end{array}$ & $\begin{array}{c}\text { Price } \\
\text { controls }\end{array}$ & $\begin{array}{l}\text { Command } \\
\& \text { control } \\
\text { regulation }\end{array}$ & $\begin{array}{c}\text { Public } \\
\text { procurement }\end{array}$ & $\begin{array}{l}\text { Assessment } \\
\text { of Impact } \\
\text { on } \\
\text { Competition }\end{array}$ & $\begin{array}{l}\text { Interaction } \\
\text { with } \\
\text { Interest } \\
\text { Groups }\end{array}$ & $\begin{array}{c}\text { Complexity } \\
\text { of } \\
\text { Regulatory } \\
\text { Procedures }\end{array}$ \\
\hline $\begin{array}{l}\text { Non OECD } \\
\text { countries }\end{array}$ & & & & & & & & & & \\
\hline Argentina & 3.88 & 2.47 & 1.95 & 4.50 & 2.46 & 2.70 & 1.88 & 4.50 & 2.05 & 1.20 \\
\hline Brazil & 2.96 & 1.54 & 1.80 & 3.15 & 1.58 & 1.19 & 3.75 & 3.75 & 5.18 & 2.60 \\
\hline Bulgaria & 2.77 & 3.08 & 1.09 & 2.70 & 1.75 & 1.16 & 2.06 & 1.13 & 2.73 & 0.67 \\
\hline Colombia & 2.29 & 1.35 & 0.65 & 3.30 & 1.60 & 0.95 & 1.13 & 2.25 & 3.55 & 4.50 \\
\hline Costa Rica & 3.29 & 4.00 & 1.81 & 3.30 & 2.22 & 0.96 & 2.25 & 1.88 & 3.82 & 2.40 \\
\hline Croatia & 3.75 & 4.02 & 1.79 & 1.65 & 1.20 & 1.34 & 0.00 & 1.50 & 3.41 & 0.50 \\
\hline Cyprus & 2.00 & 3.00 & 0.86 & 2.33 & 2.11 & 1.63 & 1.50 & 1.50 & 3.41 & 1.00 \\
\hline Kazakhstan & 4.54 & 4.26 & 2.59 & 4.65 & 1.59 & 0.86 & 2.06 & 3.00 & 3.82 & 1.50 \\
\hline Malta & 2.56 & 2.65 & 0.64 & 1.65 & 1.14 & 1.20 & 0.75 & 1.50 & 3.14 & 2.00 \\
\hline Romania & 3.42 & 3.08 & 1.96 & 3.60 & 1.44 & 1.52 & 0.75 & 1.50 & 2.45 & 2.50 \\
\hline $\begin{array}{l}\text { South } \\
\text { Africa }\end{array}$ & 4.21 & 3.71 & 2.03 & 3.60 & 0.98 & 1.23 & 2.25 & 2.25 & 4.91 & 4.00 \\
\hline
\end{tabular}

Note: The US is the only OECD country not included in the OECD average and variance, because the PMR data collection was not complete at the time of publication. Information refers to laws and regulations in force on 1 January 2018 and for a few countries 1 January 2019.

Source: OECD 2018 PMR database. 
Table A.3. Values of the low-level indicators included in Barriers to Domestic and Foreign Entry (OECD countries)

\begin{tabular}{|c|c|c|c|c|c|c|c|c|}
\hline & \multicolumn{8}{|c|}{ Barriers to Domestic and Foreign Entry } \\
\hline & $\begin{array}{l}\text { Admin. Requirements } \\
\text { for Limited Liability } \\
\text { Companies and } \\
\text { Personally-Owned } \\
\text { Enterprises }\end{array}$ & $\begin{array}{l}\text { Licenses } \\
\text { and } \\
\text { Permits }\end{array}$ & $\begin{array}{l}\text { Barriers in } \\
\text { Services } \\
\text { sectors }\end{array}$ & $\begin{array}{l}\text { Barriers in } \\
\text { Network } \\
\text { sectors }\end{array}$ & $\begin{array}{c}\text { Barriers } \\
\text { to FDI }\end{array}$ & $\begin{array}{c}\text { Tariff } \\
\text { Barriers }\end{array}$ & $\begin{array}{l}\text { Treatment } \\
\text { of Foreign } \\
\text { Suppliers }\end{array}$ & $\begin{array}{l}\text { Barriers to } \\
\text { Trade } \\
\text { Facilitation }\end{array}$ \\
\hline \multicolumn{9}{|l|}{ OECD countries } \\
\hline Australia & 0.19 & 2.00 & 1.39 & 0.62 & 0.88 & 0.00 & 1.29 & 0.75 \\
\hline Austria & 0.88 & 1.00 & 2.87 & 1.21 & 0.64 & 0.00 & 1.25 & 0.94 \\
\hline Belgium & 0.75 & 3.00 & 3.73 & 1.47 & 0.24 & 0.00 & 1.50 & 0.83 \\
\hline Canada & 0.00 & 4.00 & 3.22 & 1.07 & 0.97 & 0.00 & 1.93 & 1.13 \\
\hline Chile & 0.38 & 1.67 & 1.71 & 1.48 & 0.34 & 1.00 & 1.93 & 1.52 \\
\hline Czech Republic & 0.44 & 3.00 & 1.70 & 1.33 & 0.06 & 0.00 & 0.96 & 1.20 \\
\hline Denmark & 0.31 & 0.00 & 1.34 & 1.34 & 0.20 & 0.00 & 0.46 & 0.89 \\
\hline Estonia & 0.63 & 2.40 & 1.14 & 1.32 & 0.11 & 0.00 & 0.86 & 0.90 \\
\hline Finland & 0.31 & 1.00 & 2.67 & 1.25 & 0.11 & 0.00 & 0.86 & 1.09 \\
\hline France & 1.13 & 2.00 & 2.70 & 1.01 & 0.27 & 0.00 & 1.14 & 0.74 \\
\hline Germany & 1.13 & 0.00 & 1.66 & 0.87 & 0.14 & 0.00 & 1.00 & 0.62 \\
\hline Greece & 0.25 & 1.20 & 2.48 & 1.42 & 0.19 & 0.00 & 1.18 & 1.34 \\
\hline Hungary & 0.88 & 0.33 & 2.25 & 1.58 & 0.17 & 0.00 & 1.07 & 1.31 \\
\hline Iceland & 1.50 & 2.00 & 2.85 & 2.19 & 1.00 & 0.00 & 0.96 & 0.96 \\
\hline Ireland & 0.50 & 3.00 & 1.84 & 1.36 & 0.26 & 0.00 & 0.43 & 0.67 \\
\hline Israel & 0.63 & 1.00 & 1.55 & 1.96 & 0.71 & 0.50 & 2.68 & 1.36 \\
\hline Italy & 0.54 & 0.00 & 3.70 & 0.97 & 0.31 & 0.00 & 1.02 & 1.04 \\
\hline Japan & 1.19 & 0.00 & 1.43 & 1.34 & 0.31 & 0.00 & 1.55 & 1.01 \\
\hline Korea & 0.19 & 2.00 & 3.13 & 2.04 & 0.81 & 2.50 & 1.61 & 1.04 \\
\hline Latvia & 0.00 & 0.00 & 2.34 & 1.48 & 0.13 & 0.00 & 0.75 & 0.48 \\
\hline Lithuania & 0.13 & 0.00 & 1.40 & 1.27 & 0.11 & 0.00 & 0.80 & 0.29 \\
\hline Luxembourg & 0.75 & 2.00 & 3.18 & 1.39 & 0.02 & 0.00 & 0.80 & 0.76 \\
\hline Mexico & 1.00 & 0.33 & 2.21 & 1.34 & 1.13 & 1.50 & 3.43 & 1.79 \\
\hline Netherlands & 0.50 & 3.00 & 1.11 & 1.30 & 0.09 & 0.00 & 0.46 & 0.47 \\
\hline New Zealand & 0.00 & 1.00 & 0.79 & 1.48 & 1.39 & 0.00 & 0.25 & 1.03 \\
\hline Norway & 0.44 & 1.00 & 1.23 & 1.45 & 0.51 & 0.00 & 1.11 & 0.92 \\
\hline Poland & 1.06 & 1.33 & 2.54 & 1.40 & 0.43 & 0.00 & 0.96 & 0.81 \\
\hline Portugal & 0.63 & 0.00 & 3.70 & 1.14 & 0.04 & 0.00 & 0.89 & 0.77 \\
\hline Slovak Republic & 0.75 & 3.60 & 2.36 & 1.34 & 0.29 & 0.00 & 0.64 & 1.00 \\
\hline Slovenia & 0.38 & 1.20 & 2.03 & 1.56 & 0.04 & 0.00 & 0.98 & 0.73 \\
\hline Spain & 0.38 & 0.00 & 2.69 & 1.06 & 0.13 & 0.00 & 0.91 & 0.87 \\
\hline Sweden & 0.25 & 2.00 & 0.56 & 0.97 & 0.35 & 0.00 & 0.43 & 0.92 \\
\hline Switzerland & 0.75 & 1.20 & 0.46 & 2.50 & 0.50 & 0.00 & 1.42 & 1.45 \\
\hline Turkey & 2.50 & 5.00 & 3.09 & 1.54 & 0.35 & 0.00 & 2.23 & 1.43 \\
\hline United Kingdom & 0.38 & 2.00 & 0.61 & 0.56 & 0.24 & 0.00 & 0.54 & 0.79 \\
\hline OECD average & 0.62 & 1.52 & 2.10 & 1.36 & 0.39 & 0.16 & 1.15 & 0.97 \\
\hline $\begin{array}{l}\text { Average of } 5 \\
\text { OECD best } \\
\text { performing } \\
\text { countries }\end{array}$ & 0.06 & 0.00 & 0.70 & 0.80 & 0.05 & 0.00 & 0.41 & 0.51 \\
\hline OECD variance & 0.24 & 1.62 & 0.84 & 0.15 & 0.12 & 0.25 & 0.42 & 0.10 \\
\hline
\end{tabular}


Table A.3. continued (non-OECD countries)

\begin{tabular}{|c|c|c|c|c|c|c|c|c|}
\hline & \multicolumn{8}{|c|}{ Barriers to Domestic and Foreign Entry } \\
\hline & $\begin{array}{l}\text { Admin. } \\
\text { Requirements for } \\
\text { Limited Liability } \\
\text { Companies and } \\
\text { Personally-Owned } \\
\text { Enterprises }\end{array}$ & $\begin{array}{l}\text { Licenses } \\
\text { and } \\
\text { Permits }\end{array}$ & $\begin{array}{l}\text { Barriers in } \\
\text { Services } \\
\text { sectors }\end{array}$ & $\begin{array}{l}\text { Barriers in } \\
\text { Network } \\
\text { sectors }\end{array}$ & $\begin{array}{l}\text { Barriers } \\
\text { to FDI }\end{array}$ & $\begin{array}{c}\text { Tariff } \\
\text { Barriers }\end{array}$ & $\begin{array}{l}\text { Treatment of } \\
\text { Foreign } \\
\text { Suppliers }\end{array}$ & $\begin{array}{l}\text { Barriers to } \\
\text { Trade } \\
\text { Facilitation }\end{array}$ \\
\hline \multicolumn{9}{|l|}{$\begin{array}{l}\text { Non OECD } \\
\text { countries }\end{array}$} \\
\hline Argentina & 1.50 & 4.00 & 4.18 & 2.34 & 0.19 & 3.50 & 2.20 & 1.13 \\
\hline Brazil & 1.75 & 4.00 & 2.35 & 2.15 & 0.55 & 4.00 & 1.71 & 1.65 \\
\hline Bulgaria & 2.50 & 4.33 & 2.71 & 1.44 & 0.19 & 0.00 & 1.06 & 0.79 \\
\hline Colombia & 1.17 & 4.33 & 2.40 & 1.53 & 0.16 & 0.50 & 2.36 & 0.93 \\
\hline Costa Rica & 2.13 & 3.00 & 2.53 & 3.16 & 0.29 & 0.50 & 1.82 & 0.94 \\
\hline Croatia & 1.00 & 1.00 & 2.22 & 1.06 & 0.21 & 0.00 & 1.30 & 0.51 \\
\hline Cyprus & 3.00 & 2.00 & 2.90 & 1.30 & 0.19 & 0.00 & 0.75 & 0.80 \\
\hline Kazakhstan & 0.13 & 1.00 & 2.21 & 2.28 & 0.67 & 1.00 & 2.96 & 1.93 \\
\hline Malta & 0.44 & 2.00 & 2.69 & 2.36 & 0.19 & 0.00 & 0.83 & 0.43 \\
\hline Romania & 1.69 & 2.40 & 3.21 & 1.19 & 0.05 & 0.00 & 1.50 & 0.55 \\
\hline South Africa & 0.50 & 4.00 & 3.53 & 2.64 & 0.33 & 1.50 & 2.23 & 0.83 \\
\hline
\end{tabular}

Note: The US is the only OECD country not included in the OECD average and variance, because the PMR data collection was not complete at the time of publication. Information refers to laws and regulations in force on 1 January 2018 and for a few countries 1 January 2019.

Source: OECD 2018 PMR database. 


\section{Annex B. Values of all sector PMR indicators}

103. This Annex includes the tables with the values of all the sector PMR indicators.

104. Table B1 contains the values of the indicators for network sectors: Energy (Electricity and Natural Gas), E-communications (Fixed and Mobile) and Transport (Air, Rail, Road and Water).

105. Table B2 contains the values of the six indicators for professional services (Accountants, Architects, Civil engineers, Real estate agents, Lawyers, and Notaries) and the two indicators on retail distribution (Retail Trade and Retail Sales of Medicines). 
Table B.1. Values of the indicators for network sectors: Energy, E-communications and Transport (OECD countries)

\begin{tabular}{|c|c|c|c|c|c|c|c|c|c|c|c|c|}
\hline & \multirow{2}{*}{$\begin{array}{c}\text { Total } \\
\text { network } \\
\text { sectors }\end{array}$} & \multicolumn{3}{|c|}{ Energy } & \multicolumn{5}{|c|}{ Transport } & \multicolumn{3}{|c|}{ Ecommunications } \\
\hline & & Total & Electricity & $\begin{array}{c}\text { Natural } \\
\text { Gas }\end{array}$ & Total & $\begin{array}{l}\text { by } \\
\text { Rail }\end{array}$ & $\begin{array}{l}\text { by } \\
\text { Air }\end{array}$ & $\begin{array}{l}\text { by } \\
\text { Road }\end{array}$ & $\begin{array}{c}\text { by } \\
\text { Water }\end{array}$ & Total & $\begin{array}{l}\text { Fixed } \\
\text { Ecomm }\end{array}$ & $\begin{array}{l}\text { Mobile } \\
\text { Ecomm }\end{array}$ \\
\hline \multicolumn{13}{|l|}{ OECD countries } \\
\hline Australia & 1.12 & 0.61 & 0.64 & 0.58 & 1.50 & 2.79 & 0.50 & 1.36 & 1.38 & 0.88 & 0.95 & 0.80 \\
\hline Austria & 1.30 & 1.09 & 1.20 & 0.98 & 1.80 & 3.86 & 0.73 & 1.07 & 1.54 & 0.51 & 0.85 & 0.17 \\
\hline Belgium & 1.40 & 0.87 & 1.14 & 0.60 & 1.88 & 3.40 & 1.63 & 1.50 & 1.00 & 0.96 & 1.00 & 0.92 \\
\hline Canada & 1.34 & 1.35 & 1.39 & 1.31 & 1.66 & 2.36 & 0.92 & 1.21 & 2.17 & 0.68 & 0.75 & 0.60 \\
\hline Chile & 1.49 & 1.68 & 0.64 & 2.71 & 1.67 & 3.64 & 1.00 & 0.50 & 1.54 & 0.93 & 0.35 & 1.50 \\
\hline Czech Republic & 1.23 & 0.67 & 1.03 & 0.31 & 2.01 & 4.43 & 0.92 & 1.43 & 1.25 & 0.22 & 0.45 & 0.00 \\
\hline Denmark & 0.99 & 0.96 & 0.93 & 1.00 & 1.41 & 2.36 & 0.11 & 1.36 & 1.83 & 0.18 & 0.15 & 0.20 \\
\hline Estonia & 1.33 & 0.87 & 1.35 & 0.38 & 2.13 & 3.50 & 1.75 & 1.93 & 1.32 & 0.21 & 0.42 & 0.00 \\
\hline Finland & 1.52 & 1.78 & 0.75 & 2.80 & 2.09 & 4.50 & 1.23 & 1.86 & 0.75 & 0.14 & 0.21 & 0.06 \\
\hline France & 1.68 & 1.78 & 1.64 & 1.92 & 2.09 & 4.71 & 0.72 & 1.64 & 1.29 & 0.77 & 0.81 & 0.74 \\
\hline Germany & 1.08 & 0.44 & 0.50 & 0.38 & 1.50 & 3.00 & 0.24 & 1.71 & 1.04 & 0.87 & 0.94 & 0.79 \\
\hline Greece & 1.19 & 1.46 & 1.79 & 1.13 & 1.45 & 1.71 & 0.93 & 1.93 & 1.23 & 0.40 & 0.44 & 0.36 \\
\hline Hungary & 1.50 & 1.45 & 1.50 & 1.40 & 2.18 & 4.07 & 1.00 & 1.86 & 1.79 & 0.19 & 0.38 & 0.01 \\
\hline Iceland & 1.08 & 2.11 & 2.11 & & 1.10 & & 1.00 & 1.21 & 1.09 & 0.54 & 0.28 & 0.80 \\
\hline Ireland & 1.26 & 0.93 & 1.48 & 0.38 & 2.03 & 4.71 & 0.58 & 1.57 & 1.25 & 0.04 & 0.08 & 0.00 \\
\hline Israel & 1.90 & 1.47 & 2.61 & 0.33 & 2.31 & 5.14 & 1.75 & 1.86 & 0.50 & 1.50 & 1.50 & 1.50 \\
\hline Italy & 1.06 & 1.16 & 1.17 & 1.14 & 1.33 & 3.29 & 0.00 & 1.14 & 0.88 & 0.45 & 0.30 & 0.60 \\
\hline Japan & 1.49 & 1.23 & 1.46 & 1.00 & 1.50 & 2.14 & 1.21 & 1.14 & 1.52 & 1.71 & 1.49 & 1.92 \\
\hline Korea & 1.98 & 3.09 & 2.89 & 3.29 & 1.81 & 3.57 & 0.73 & 1.71 & 1.21 & 1.20 & 1.60 & 0.80 \\
\hline Latvia & 1.58 & 1.42 & 2.21 & 0.62 & 1.84 & 3.00 & 1.52 & 1.64 & 1.21 & 1.21 & 0.98 & 1.44 \\
\hline Lithuania & 1.95 & 2.14 & 2.51 & 1.77 & 2.35 & 3.86 & 2.25 & 1.43 & 1.87 & 0.94 & 0.98 & 0.90 \\
\hline Luxembourg & 1.80 & 0.91 & 0.85 & 0.96 & 2.26 & 4.10 & 2.30 & 1.14 & 1.50 & 1.76 & 1.58 & 1.95 \\
\hline Mexico & 1.88 & 2.25 & 2.14 & 2.36 & 2.06 & 3.60 & 1.91 & 1.43 & 1.29 & 1.15 & 1.50 & 0.80 \\
\hline Netherlands & 0.97 & 0.75 & 0.71 & 0.78 & 1.54 & 2.71 & 0.99 & 1.36 & 1.08 & 0.08 & 0.15 & 0.00 \\
\hline New Zealand & 1.70 & 1.93 & 1.79 & 2.08 & 1.56 & 3.29 & 0.71 & 0.63 & 1.63 & 1.73 & 2.66 & 0.80 \\
\hline Norway & 1.76 & 1.93 & 1.21 & 2.64 & 1.92 & 4.21 & 0.95 & 1.35 & 1.18 & 1.26 & 1.30 & 1.22 \\
\hline Poland & 1.63 & 1.98 & 2.17 & 1.79 & 2.20 & 3.57 & 1.75 & 1.50 & 2.00 & 0.14 & 0.08 & 0.20 \\
\hline Portugal & 1.22 & 0.49 & 0.14 & 0.84 & 1.98 & 3.64 & 0.67 & 1.43 & 2.19 & 0.44 & 0.68 & 0.20 \\
\hline Slovak Republic & 1.41 & 1.98 & 1.95 & 2.01 & 1.79 & 3.86 & 0.36 & 1.14 & 1.79 & 0.08 & 0.15 & 0.00 \\
\hline Slovenia & 1.74 & 1.26 & 1.41 & 1.10 & 2.32 & 5.14 & 1.00 & 2.14 & 0.99 & 1.07 & 1.11 & 1.04 \\
\hline Spain & 1.09 & 0.73 & 1.00 & 0.47 & 1.69 & 4.71 & 0.34 & 1.35 & 0.38 & 0.24 & 0.28 & 0.20 \\
\hline Sweden & 1.35 & 0.97 & 1.63 & 0.31 & 1.58 & 3.00 & 1.48 & 0.79 & 1.04 & 1.30 & 1.27 & 1.32 \\
\hline Switzerland & 2.59 & 3.48 & 2.83 & 4.13 & 2.29 & 3.50 & 1.27 & 2.03 & 2.38 & 2.31 & 1.61 & 3.01 \\
\hline Turkey & 1.94 & 1.94 & 1.68 & 2.21 & 2.54 & 3.86 & 2.16 & 2.36 & 1.77 & 0.73 & 1.46 & 0.00 \\
\hline United Kingdom & 0.56 & 0.00 & 0.00 & 0.00 & 1.04 & 2.14 & 0.17 & 0.82 & 1.04 & 0.15 & 0.30 & 0.00 \\
\hline OECD average & 1.46 & 1.40 & 1.44 & 1.34 & 1.84 & 3.57 & 1.05 & 1.44 & 1.37 & 0.77 & 0.83 & 0.71 \\
\hline $\begin{array}{l}\text { Average of } 5 \\
\text { OECD best } \\
\text { performing } \\
\text { countries }\end{array}$ & 0.93 & 0.44 & 0.39 & 0.27 & 1.27 & 2.14 & 0.17 & 0.76 & 0.70 & 0.09 & 0.12 & 0.00 \\
\hline OECD Variance & 0.15 & 0.52 & 0.50 & 0.94 & 0.13 & 0.73 & 0.37 & 0.17 & 0.20 & 0.33 & 0.36 & 0.48 \\
\hline
\end{tabular}


$\mathbf{5 8} \mid \operatorname{ECO}$ WKP(2020)12

Table B1 continued (non-OECD countries)

\begin{tabular}{|c|c|c|c|c|c|c|c|c|c|c|c|c|}
\hline & \multirow{2}{*}{$\begin{array}{c}\text { Total } \\
\text { network } \\
\text { sectors }\end{array}$} & \multicolumn{3}{|c|}{ Energy } & \multicolumn{5}{|c|}{ Transport } & \multicolumn{3}{|c|}{ Ecommunications } \\
\hline & & Total & Electricity & $\begin{array}{l}\text { Natural } \\
\text { Gas }\end{array}$ & Total & $\begin{array}{l}\text { by } \\
\text { Rail }\end{array}$ & $\begin{array}{l}\text { by } \\
\text { Air }\end{array}$ & $\begin{array}{l}\text { by } \\
\text { Road }\end{array}$ & $\begin{array}{c}\text { by } \\
\text { Water }\end{array}$ & Total & $\begin{array}{l}\text { Fixed } \\
\text { Ecomm }\end{array}$ & $\begin{array}{l}\text { Mobile } \\
\text { Ecomm }\end{array}$ \\
\hline \multicolumn{13}{|l|}{$\begin{array}{l}\text { Non OECD } \\
\text { countries }\end{array}$} \\
\hline Argentina & 2.58 & 2.37 & 2.24 & 2.50 & 2.88 & 3.50 & 3.94 & 1.57 & 2.50 & 2.17 & 2.55 & 1.80 \\
\hline Brazil & 1.94 & 2.53 & 2.06 & 2.99 & 2.29 & 4.07 & 0.67 & 2.00 & 2.42 & 0.68 & 0.75 & 0.60 \\
\hline Bulgaria & 1.35 & 1.62 & 1.23 & 2.00 & 1.81 & 3.00 & 1.18 & 1.36 & 1.69 & 0.18 & 0.15 & 0.20 \\
\hline Colombia & 1.41 & 1.60 & 1.68 & 1.52 & 1.34 & 1.20 & 1.13 & 2.00 & 1.03 & 1.36 & 1.44 & 1.27 \\
\hline Costa Rica & 2.96 & 4.50 & 4.50 & & 3.03 & 4.71 & 2.63 & 1.86 & 2.92 & 2.05 & 2.36 & 1.74 \\
\hline Croatia & 1.53 & 1.49 & 1.50 & 1.48 & 2.15 & 3.86 & 1.42 & 1.14 & 2.17 & 0.35 & 0.69 & 0.02 \\
\hline Cyprus & 1.58 & 2.93 & 2.93 & & 0.97 & . & 1.00 & 1.65 & 0.25 & 1.84 & 1.88 & 1.80 \\
\hline Kazakhstan & 2.60 & 2.66 & 2.82 & 2.50 & 2.39 & 3.00 & 3.09 & 1.36 & 2.13 & 2.95 & 3.61 & 2.30 \\
\hline Malta & 1.44 & 3.83 & 3.83 & & 1.36 & . & 1.35 & 1.00 & 1.73 & 0.38 & 0.55 & 0.20 \\
\hline Romania & 1.73 & 1.87 & 2.20 & 1.53 & 2.11 & 4.14 & 1.47 & 1.43 & 1.41 & 0.84 & 1.34 & 0.34 \\
\hline South Africa & 2.59 & 3.52 & 4.62 & 2.42 & 2.20 & 4.29 & 2.24 & 1.71 & 0.55 & 2.46 & 2.54 & 2.38 \\
\hline
\end{tabular}

Note: The US is the only OECD country not included in the OECD average and variance, because the PMR data collection was not complete at the time of publication. Information refers to laws and regulations in force on 1 January 2018 and for a few countries 1 January 2019.

Source: OECD 2018 PMR database. 
Table B.2. Values of the indicators for professional services and for retail distribution (OECD countries)

\begin{tabular}{|c|c|c|c|c|c|c|c|c|}
\hline & \multicolumn{6}{|c|}{ Professional Services } & \multicolumn{2}{|c|}{ Retail Distribution } \\
\hline & Accountants & Architects & $\begin{array}{c}\text { Civil } \\
\text { engineers }\end{array}$ & $\begin{array}{l}\text { Real estate } \\
\text { agents }\end{array}$ & Lawyers & Notaries & $\begin{array}{l}\text { Retail } \\
\text { trade }\end{array}$ & $\begin{array}{l}\text { Retail Sales of } \\
\text { Medicines }\end{array}$ \\
\hline \multicolumn{9}{|l|}{ OECD countries } \\
\hline Australia & 0.00 & 0.95 & 0.30 & 0.50 & 1.35 & . & 0.47 & 3.88 \\
\hline Austria & 1.70 & 2.53 & 2.80 & 1.21 & 3.15 & 4.24 & 2.01 & 4.00 \\
\hline Belgium & 2.47 & 2.95 & 0.00 & 2.95 & 3.41 & 4.46 & 2.52 & 3.75 \\
\hline Canada & 3.44 & 3.54 & 2.05 & 1.43 & 2.61 & . & 1.84 & 1.50 \\
\hline Chile & 0.00 & 0.66 & 1.00 & 0.13 & 1.00 & 5.02 & 0.12 & 1.50 \\
\hline Czech Republic & 0.60 & 2.29 & 2.55 & 0.00 & 4.24 & 5.31 & 1.24 & 0.50 \\
\hline Denmark & 0.13 & 0.75 & 0.00 & 1.46 & 3.01 & . & 1.01 & 1.25 \\
\hline Estonia & 0.00 & 1.05 & 0.85 & 0.00 & 3.88 & 5.52 & 0.38 & 1.88 \\
\hline Finland & 0.00 & 0.00 & 0.00 & 0.50 & 2.51 & . & 1.65 & 3.75 \\
\hline France & 2.74 & 2.22 & 0.34 & 0.97 & 3.75 & 3.54 & 2.00 & 4.25 \\
\hline Germany & 2.59 & 1.34 & 2.36 & 0.19 & 3.36 & 5.43 & 0.48 & 2.50 \\
\hline Greece & 1.26 & 1.80 & 1.80 & 0.21 & 3.90 & 5.18 & 2.54 & 3.50 \\
\hline Hungary & 1.19 & 1.88 & 0.98 & 0.86 & 4.57 & 5.22 & 1.12 & 2.38 \\
\hline Iceland & 0.00 & 1.96 & 0.94 & 2.24 & 3.90 & . & 1.66 & 0.75 \\
\hline Ireland & 0.00 & 1.00 & 1.81 & 0.36 & 3.13 & . & 0.94 & 1.38 \\
\hline Israel & 0.00 & 1.14 & 1.09 & 0.93 & 4.30 & 3.68 & 0.55 & 0.75 \\
\hline Italy & 2.61 & 2.67 & 2.15 & 1.07 & 2.33 & 4.69 & 2.79 & 2.57 \\
\hline Japan & 2.14 & 1.40 & 0.65 & 0.90 & 3.35 & 5.00 & 0.94 & 1.00 \\
\hline Korea & 4.18 & 3.17 & 3.22 & 3.50 & 4.28 & 4.88 & 1.25 & 3.75 \\
\hline Latvia & 0.00 & 2.10 & 2.20 & 0.75 & 3.36 & 5.42 & 1.29 & 3.63 \\
\hline Lithuania & 0.00 & 1.46 & 0.95 & 0.00 & 3.34 & 4.88 & 0.91 & 1.75 \\
\hline Luxembourg & 1.89 & 2.17 & 2.47 & 0.50 & 3.45 & 5.02 & 1.71 & 5.43 \\
\hline Mexico & 0.70 & 0.80 & 0.70 & 1.71 & 1.00 & 4.71 & 1.41 & 0.25 \\
\hline Netherlands & 0.84 & 0.15 & 0.00 & 0.00 & 3.34 & 3.60 & 0.97 & 0.38 \\
\hline New Zealand & 0.39 & 0.15 & 0.15 & 1.00 & 3.27 & . & 0.76 & 1.38 \\
\hline Norway & 1.15 & 0.05 & 0.05 & 1.27 & 3.01 & . & 0.13 & 0.00 \\
\hline Poland & 0.00 & 1.90 & 1.85 & 0.00 & 4.25 & 4.67 & 1.30 & 3.88 \\
\hline Portugal & 1.96 & 1.10 & 2.20 & 0.36 & 3.71 & 4.80 & 2.55 & 3.88 \\
\hline Slovak Republic & 0.38 & 3.41 & 3.29 & 0.86 & 4.03 & 5.33 & 1.54 & 1.25 \\
\hline Slovenia & 0.00 & 1.89 & 1.64 & 1.30 & 3.99 & 5.30 & 1.15 & 3.38 \\
\hline Spain & 0.00 & 1.00 & 0.95 & 0.07 & 1.81 & 5.14 & 1.67 & 4.75 \\
\hline Sweden & 0.00 & 0.00 & 0.00 & 1.41 & 2.03 & 0.07 & 0.53 & 0.00 \\
\hline Switzerland & 0.30 & 0.00 & 0.00 & 0.13 & 2.96 & . & 0.68 & 0.75 \\
\hline Turkey & 4.80 & 2.89 & 3.20 & 0.00 & 4.57 & 5.39 & 1.91 & 6.00 \\
\hline United Kingdom & 1.07 & 0.15 & 0.35 & 0.00 & 1.60 & . & 0.03 & 1.50 \\
\hline OECD average & 1.10 & 1.50 & 1.28 & 0.82 & 3.19 & 4.66 & 1.26 & 2.37 \\
\hline $\begin{array}{l}\text { Average of } 5 \text { OECD best } \\
\text { performing countries }\end{array}$ & 0.00 & 0.04 & 0.00 & 0.00 & 1.35 & 3.03 & 0.22 & 0.23 \\
\hline OECD Variance & 1.70 & 1.06 & 1.11 & 0.69 & 0.93 & 1.19 & 0.52 & 2.60 \\
\hline
\end{tabular}




\section{0 | $\operatorname{ECO} / \operatorname{WKP}(2020) 12$}

Table B.2 continued (non-OECD countries)

\begin{tabular}{|c|c|c|c|c|c|c|c|c|}
\hline & \multicolumn{6}{|c|}{ Professional Services } & \multicolumn{2}{|c|}{ Retail Distribution } \\
\hline & Accountants & Architects & $\begin{array}{c}\text { Civil } \\
\text { engineers }\end{array}$ & $\begin{array}{c}\text { Real estate } \\
\text { agents }\end{array}$ & Lawyers & Notaries & $\begin{array}{l}\text { Retail } \\
\text { trade }\end{array}$ & $\begin{array}{c}\text { Retail Sales of } \\
\text { Medicines }\end{array}$ \\
\hline \multicolumn{9}{|c|}{ Non-OECD countries } \\
\hline Argentina & 3.44 & 3.43 & 1.36 & 2.31 & 2.07 & 5.46 & 2.85 & 5.00 \\
\hline Brazil & 3.33 & 2.13 & 2.17 & 2.21 & 4.81 & 5.01 & 1.00 & 1.25 \\
\hline Bulgaria & 0.00 & 2.65 & 2.50 & 0.00 & 4.59 & 5.29 & 1.56 & 1.75 \\
\hline Colombia & 2.10 & 1.31 & 1.41 & 0.38 & 1.78 & 5.07 & 0.89 & 1.50 \\
\hline Costa Rica & 1.81 & 1.67 & 1.73 & 0.00 & 2.83 & 2.78 & 1.51 & 1.00 \\
\hline Croatia & 0.00 & 1.15 & 1.40 & 1.00 & 3.85 & 5.29 & 1.22 & 4.50 \\
\hline Cyprus & 0.75 & 2.38 & 2.00 & 3.74 & 3.44 & . & 1.29 & 2.88 \\
\hline Kazakhstan & 1.85 & 1.17 & 1.00 & 0.00 & 2.40 & 4.70 & 1.15 & 1.00 \\
\hline Malta & 1.88 & 1.71 & 1.71 & 0.00 & 3.60 & 4.71 & 1.35 & 4.75 \\
\hline Romania & 3.28 & 2.34 & 0.75 & 1.29 & 3.90 & 5.54 & 1.35 & 1.50 \\
\hline South Africa & 1.25 & 2.64 & 2.06 & 1.95 & 4.36 & . & 2.55 & 4.75 \\
\hline
\end{tabular}

Note: The US is the only OECD country not included in the OECD average and variance, because the PMR data collection was not complete at the time of publication. Information refers to laws and regulations in force on 1 January 2018 and for a few countries 1 January 2019.

Source: OECD 2018 PMR database. 


\section{Annex C. How have the PMR indicators changed in 2018?}

106. The methodology to calculate the 2018 economy-wide and sector PMR indicators has changed considerably from the one used in the 2013 vintage. The evolution in the economic theory, the modifications in the economic and business environment, and the changes in the practice of regulation that have taken place since the PMR indicators were first designed called for a substantial review of the methodology.

107. This Annex provides an overview of the changes that have been made as a result of this review. These changes have affected the questionnaire, the scoring methodology and the composition of the two sets of indicators. A more detailed description of the 2018 methodology can be found in the paper, "2018 PMR indicators: the methodology", which is available on the PMR webpage.

\section{$A$ revised questionnaire}

108. The questionnaire that the OECD uses to collect the information necessary to compute the PMR indicators has been considerably modified in 2018.

109. The main additions made to the questionnaire include:

- A new horizontal area on the simplification and design of regulations, which explores the process through which new regulations are introduced, to determine whether there are adequate mechanisms in place to reduce the risk of unnecessary restraints to competition. Such mechanisms include regulatory impact assessments, rules that regulate the interaction of public officials with interest groups, stakeholder engagement, and tools for competition advocacy. ${ }^{21}$

- Questions on the rules for the public procurement of goods, services and public works, which assess whether such rules create unnecessary barriers for domestic and foreign suppliers, discouraging firms from participating in public tenders and reducing or distorting competition for public contracts.

- A new profession: real estate agents.

- Questions on the retail sale of medicines and on pre-booked passenger transport services in metropolitan areas (provided by taxis and other operators).

- Questions on the regulation of long-distance passenger transportation services by coach.

Additional important changes include:

21 A few questions on how new regulations are assessed were already included in the previous PMR questionnaire, but the new questionnaire includes a more extensive set of questions. 
- A complete revision of the section on telecommunications, now called e-communications, to ensure that it covers the regulation of all key bottlenecks in fixed and mobile networks, and that it includes both voice and data services.

- An update of questions on the governance of state-owned enterprise, on vertical separation in network industries, and on mobile roaming charges to reflect OECD Guidelines and Recommendations, such as those on State-Owned Enterprises, on International Roaming, and on Structural Separation 22 .

- A review of the questions on professions to focus on individual professions rather than on groups of professions, to ensure greater precision and comparability. This has led to the creation of two separate indicators for legal professions: one focusing on lawyers and one on notaries.

- Additional question on quantitative restrictions to entry and on limitations to the activities professionals can undertake, as well as on constraints to ownership and voting rights in professional firms.

- The exclusion of postal services, since the number of letters delivered in OECD countries is rapidly decreasing, as e-mails are becoming the most common means of written communication, while the delivery of parcels, which is growing with the development of e-commerce, is a rather competitive sector.

110. The final version of the 2018 PMR questionnaire is available on the OECD PMR webpage.

\section{A revised scoring methodology}

111. The information collected through the questionnaire is transformed in numerical values (0 to 6$)$ using a scoring methodology based on international accepted best practices. This methodology has also been reviewed to accommodate the changes in the questionnaire, but also to capture modification in theory and practice of regulation. This methodology is outlined in the two PMR Schemata, which are available on the PMR website.

\section{The 2018 structure of the economy-wide PMR indicator and the differences with the 2013 structure}

112. The structure of the economy-wide indicator has been revised to accommodate the new information collected via the new questionnaire, as well as to ensure that the sub-level indicators remain balanced.

113. The 2018 economy-wide indicator has now a two-legged structure, while it had three legs in 2013 (Figure 40). The composition of the two high-level indicators in the 2018 structure is also different from previous vintages. This new structure allows users to obtain a clearer distinction between regulations affecting competition through firm entry vis-à-vis other distortions to the level playing field. In addition, it ensures that the structure is balanced, in terms of the information that is included, to avoid that certain aspects of the regulatory environment have a much greater weight compared to others in determining the value of the indicators.

22 OECD Guidelines on State-Owned Enterprises (https://www.oecd.org/corporate/guidelines-corporate-governance-soes.htm), OECD Recommendation of the Council on International Mobile Roaming Services (https://legalinstruments.oecd.org/public/doc/271/271.en.pdf), Recommendation of the OECD Council on Structural Separation in Regulated Industries (http://www.oecd.org/daf/competition/OECD-Recommendation-on-Structural-separation-regulatedindustries.pdf). 
114. To highlight the changes, Figure 39 shows in yellow the components of the indicator that have been moved or relabelled, and in red the newly added components. Figure 40 shows the structure of the economy-wide indicator in 2013.

Figure.39. Structure of the 2018 economy-wide PMR indicator with changes highlighted

\section{Product Market Regulation \\ 2018}

Distortions Induced by

State Involvement

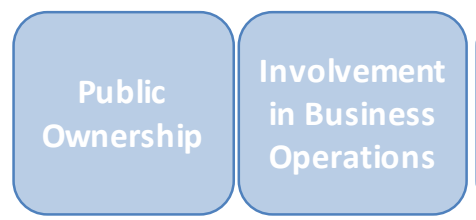

Scope of SOES

Gov't Involv. in

Network

Sectors

Direct

Control over

Enterprises

Governance of SOES

\section{Simplification and Evaluation of Regulations}

Retail Price

Controls and

Regulation

Command and Control

Regulation

Public

Procurement

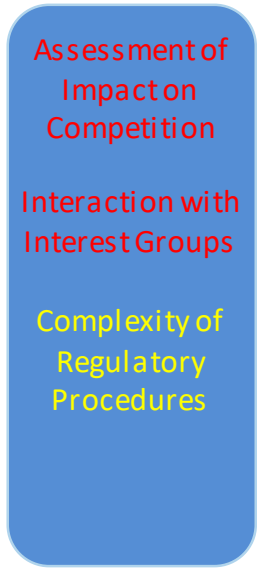

Barriers to Domestic

and Foreign Entry
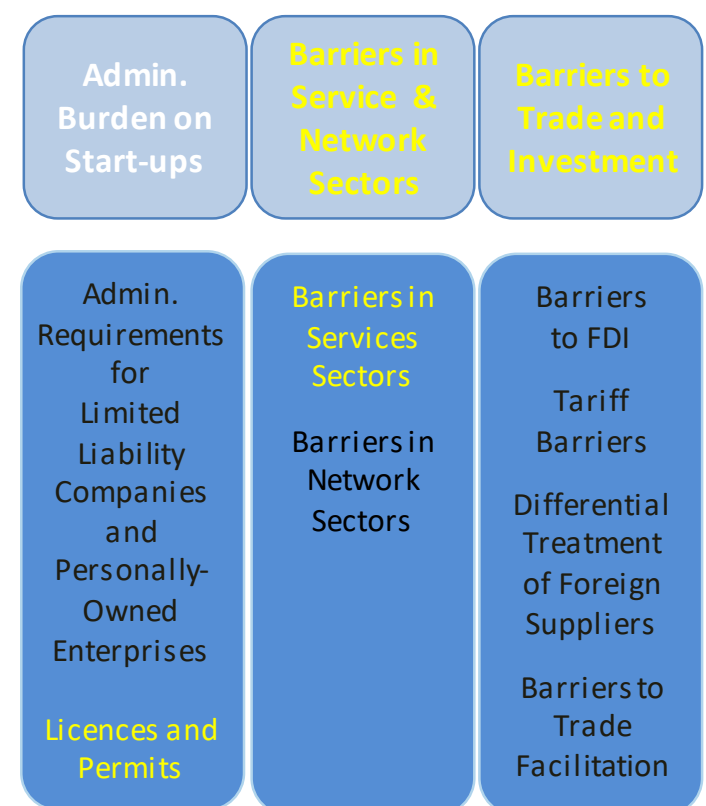

Barriers in

Services

Sectors

Barriersin

Network

Sectors

Barriers
to FDI
Tariff
Barriers
Differential
Treatment
of Foreign
Suppliers
Barriersto
Trade
Facilitation


Figure 40. Structure of the economy-wide PMR indicator in 2013

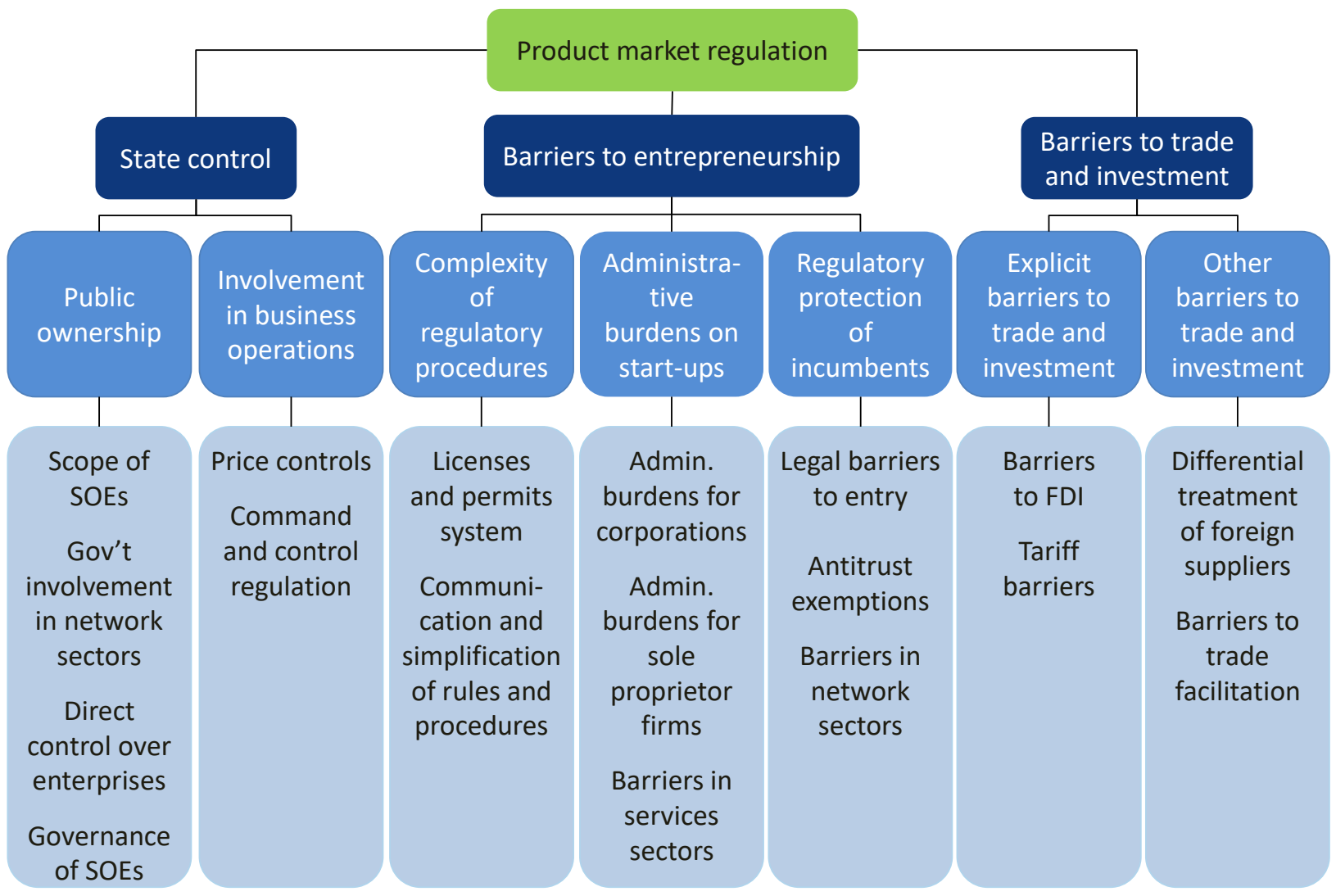

115. It should be noted that the 2018 indicator include 18 low-level indicators, as the 2013. However, in the 2018 structure there are four new low-level components new - Assessment of Impact on Competition, Interaction with Interest Groups, Public Procurement and Administrative Requirements for Limited Liability Companies and Personally-Owned Enterprises. Adding these 4 sub-indicators has been possible, because four low-level components, which were present in the 2013 structure, have been included in other components:

- The questions previously in Antitrust Exemptions have been simplified and included in Governance of SOEs, since they only concern exemptions for SOEs. Hence, there is no longer a low-level component called Antitrust Exemptions.

- The questions on legal barriers in network sectors have been moved to Barriers in Network Sectors, and the questions on legal barriers in service sectors have been moved to Barriers in Service Sectors, while the questions on legal barriers in other sectors have been removed. Hence, there is no longer a low-level component called Legal Barriers to Entry.

- The information on the requirements to set-up new firms, which were included in two low-level indicators called Administrative Burden for Corporations and Administrative Burden for PersonallyOwned Enterprises, are now included in a single sub-indicator - Administrative Requirements for Limited Liability Companies and Personally-Owned Enterprises.

116. It is important again to stress that, in addition to the more evident changes to the structure; the content of each indicator has changed to reflect the modifications and additions made to the data collected through the questionnaire. Even though many of the low-level components have the same name (or similar names) as in previous vintages and cover, to a large extent, the same regulatory areas and sectors, the 
information included in them often refers to different regulatory issues. These changes no longer permit to compare the 2018 economy-wide PMR indicator nor any of its components with previous vintages.

\section{The difference in the structure of the sector PMR indicators between 2013 and 2018}

117. The revision of the methodology has also led to changes in the structure of the sector PMR indicators. In past vintages, many of the sector indicators included only a subset of the information on each sector that was collected through the PMR questionnaire and that was included in the economy-wide indicator. In the 2018 one, the sector indicators include most of the information on the relevant sectors that is collected through the questionnaire and the same information that is included in the economy-wide indicator.

118. The increase in the information included affects mostly the indicators on network sectors, where the data included has doubled. These changes represent a significant improvement, as these new sector indicators provide a more complete and accurate assessment of regulatory barriers to competition in the sectors covered.

119. Nevertheless, also the indicators on professional services have a wider information base, since new questions in this area have bene added in the 2018 PMR questionnaire, while the indicator on retail distribution has seen some minor additions, mostly concerning restrictions to online sales.

In addition, new indicators have been added:

The indicators on Transport by water,

The indicator on E-communication is now composed of an indicator on Mobile E-communication and one on Fixed E-communication,

The indicators on Notaries and Real estate Agents, and

The indicator on the Retail Sale of Medicines.

120. The indicator on the post sector is no longer produced for the reasons mentioned above.

121. The data on the de facto level of competition is no longer included in the network sector indicators, because it had become of very limited value. The data that used to include in the sector indicators only referred to the share of the largest firm in the sector (by brackets) or to the number of competitors active in it. This information was useful when network sectors were first opened to competition, but nowadays no longer describes reliably the extent to which competition has developed. However, measuring in a more accurate way the de facto level of competition would require the use, as a minimum, of concentration ratios (CR5 or CR20) or Herfindahl-Hirschman indexes (HHI). These measures need a much wider and precise set of information, but collecting it would impose a considerable burden on respondents. In addition, the consistency and comparability of this information across countries and over time would be very difficult to guarantee, as public authorities in different countries collect this information in different manners and, in some cases, do not even collect it at all.

122. The OECD no longer computes a single indicator on the regulation of all professional services, but only six indicators, one for each profession. This is because some professions may not exist in some countries and a single average could distort comparisons.

123. These changes no longer permit to compare the 2018 PMR sector indicators with previous vintages. 


\section{References}

Aghion et al., (2009), The effects of entry on incumbent innovation and productivity. The Review of Economics and Statistics, 91(1), 20-32.

Aghion et al., (2005), Competition and Innovation: an Inverted-U Relationship. The Quarterly Journal of Economics, 120(2), 701-728.

Aghion et al., (2004), Entry and productivity growth: Evidence from microlevel panel data. Journal of the European Economic Association, 2(2-3)

Ahn, (2002), Competition, Innovation and Productivity Growth: A Review of Theory and Evidence. OECD Economics Working Paper No. 317.

Barnes,. et al. (2011), "The GDP Impact of Reform: A Simple Simulation Framework", OECD Economics Department Working Papers, No. 834.

Bloom, et al., (2011), Trade induced technical change? The impact of Chinese imports on innovation, IT and productivity. NBER Working Paper n.16717.

Blundell, Griffith and Van Reenen (1999), Market Share, Market Value and Innovation in a Panel of British Manufacturing Firms. Review of Economic Studies, 66(3), 529-54.

Bouis, and Duval (2011), "Raising Potential Growth After the Crisis: A Quantitative Assessment of the Potential Gains from Various Impact of structural reforms in the OECD Area and Beyond", OECD Economics Department Working Papers, No. 835.

Bourlès, et al. (2010), "Do Product Market Regulations in Upstream Sectors Curb Productivity Growth?: Panel Data Evidence for OECD Countries", OECD Economics Department Working Papers, No. 791.

Boylaud, Nicoletti, and Scarpetta, (2000), "Summary indicators of product market regulation with an extension to employment protection legislation" ,OECD Economics Department Working Paper No 226/2000.

Causa, et al., (2016), "The distributional impact of structural reforms", OECD Economics Department Working Papers No. 1342

Conway, et al. (2006), "Regulation, Competition and Productivity Convergence", OECD Economics Department Working Papers, No. 509

Conway, et al. (2006b), "Product Market Regulation and productivity convergence", OECD Economic Studies, No. 43.

Disney, Haskell and Heden (2003), Restructuring and productivity growth in UK manufacturing. The Economic Journal, 113(489), 666-694.

Égert, (2018), "The quantification of structural reforms: Taking stock of the results for OECD and non-OECD countries", OECD Economics Department Working Paper, No. 1482. 
Égert, (2017), "Regulation, institutions and aggregate investment: new evidence from OECD countries", OECD Economics Department Working Paper, No. 1392. (published in Open Economies Review, 2018, 29(2), 415-449).

Égert, (2017a), "The quantification of structural reforms: extending the framework to emerging market economies", OECD Economics Department Working Paper, No. 1442.

Égert, and Gal (2017), "The quantification of structural reforms in OECD countries: A new framework", OECD Economics Department Working Paper No. 1354. Shorter versions published in OECD Journal: Economic Studies, OECD Publishing, vol. 2016(1), pages 91108; and forthcoming in (1) De Grauwe and N. Campos (ed),(2018) "Structural Reforms and European Integration", Oxford University Press, (2) de Haan, J. and J. Parlevliet (2018), "The evaluation of structural reforms", Springer.

Égert, (2016), "Regulation, institutions and productivity: new macroeconomic evidence from OECD countries", American Economic Review Papers and Proceedings, 106(5), 109-113 (extended version published as OECD Economics Department Working Paper, No. 1393).

Égert, and Wanner (2016), "Regulations in services sectors and their impact on downstream industries: The OECD 2013 Regimpact Indicator", OECD Economics Department Working Papers, No. 1303.

Fiori et al., (2012), Employment Effects of Product and Labour Market Reforms: Are There Synergies?. The Economic Journal, 122(558), F79-F104.

Griffith,. et al., (2007), Product Market Reforms, Labour Market Institutions and Unemployment. The Economic Journal, 117(519), C142-C166. http://www.jstor.org/stable/4625503

Griffith, Harrison, and Simpson, (2006). The link between product market reform, innovation and EU macroeconomic performance. Economic Paper n.243. European Commission, Directorate-General for Economic and Financial Affairs. http://ec.europa.eu/economy_

Guillemette, et al. (2017), "A revised approach to productivity convergence in long-term scenarios", OECD Economics Department Working Papers, No. 1385, OECD Publishing, Paris, https://doi.org/10.1787/0b8947e3-en.

Januszewski, (2002), Product market competition, corporate governance and firm performance: an empirical analysis for Germany. Research in Economics, 56(3), 299-332.

Koske, Wanner., Bitetti , and Barbiero (2015), "The 2013 update of the OECD product market regulation indicators: policy insights for OECD and non-OECD countries", OECD Economics Department Working Papers, No. 1200.

Nickell, (1996), Competition and Corporate Performance. Journal of Political Economy 104(4), 724-746.

OECD (2008), OECD Handbook on constructing composite indicators. OECD Statistics Working Paper STD/DOC.

Parker, and Kirkpatrick (2012), "The economic impact of regulatory policy: A literature review of quantitative evidence".

Wölfl, Wanner, Kozluk, and Nicoletti (2009) "Ten years of product market reform in OECD countries - insights from a revised PMR indicator", OECD Economics Department Working Papers No.695/2009 